\title{
Characteristics of Produced Water Discharged to the Gulf of Mexico Hypoxic Zone
}

prepared by

Environmental Assessment Division

Argonne National Laboratory 


\begin{abstract}
About Argonne National Laboratory
Argonne is managed by The University of Chicago for the U.S. Department of Energy under contract W-31-109-Eng-38. The Laboratory's main facility is outside Chicago, at 9700 South Cass Avenue, Argonne, Illinois 60439. For information about Argonne and its pioneering science and technology programs, see www.anl.gov.
\end{abstract}

\title{
Availability of This Report
}

This report is available, at no cost, at http://www.osti.gov/bridge. It is also available on paper to U.S. Department of Energy and its contractors, for a processing fee, from:

U.S. Department of Energy

Office of Scientific and Technical Information

P.O. Box 62

Oak Ridge, TN 37831-0062

phone (865) 576-8401

fax (865) 576-5728

reports@adonis.osti.gov

\section{Disclaimer}

This report was prepared as an account of work sponsored by an agency of the United States Government. Neither the United States Government nor any agency thereof, nor The University of Chicago, nor any of their employees or officers, makes any warranty, express or implied, or assumes any legal liability or responsibility for the accuracy, completeness, or usefulness of any information, apparatus, product, or process disclosed, or represents that its use would not infringe privately owned rights. Reference herein to any specific commercial product, process, or service by trade name, trademark, manufacturer, or otherwise, does not necessarily constitute or imply its endorsement, recommendation, or favoring by the United States Government or any agency thereof. The views and opinions of document authors expressed herein do not necessarily state or reflect those of the United States Government or any agency thereof, Argonne National Laboratory, or The University of Chicago. 


\section{Characteristics of Produced Water Discharged to the Gulf of Mexico Hypoxic Zone}

for

U.S. Department of Energy

National Energy Technology Laboratory

by

John A.Veil, Todd A. Kimmell, and Abbey C. Rechner

Environmental Assessment Division, Argonne National Laboratory

August 2005

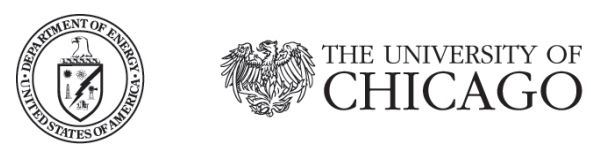

Argonne National Laboratory is managed by

The University of Chicago for the U.S. Department of Energy 



\section{CONTENTS}

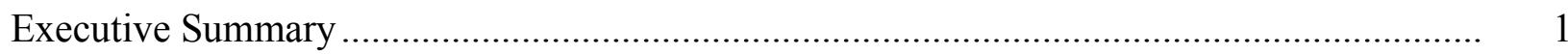

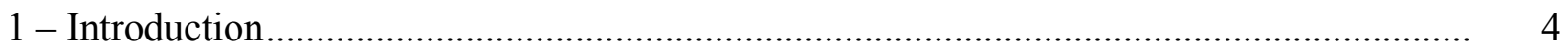

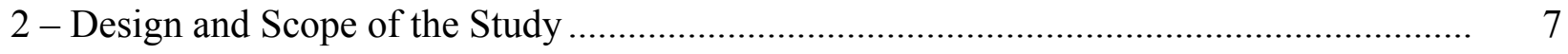

3 - Description of Platforms Selected for Sampling ......................................................... 17

4 - Sampling Results ............................................................................................ 23

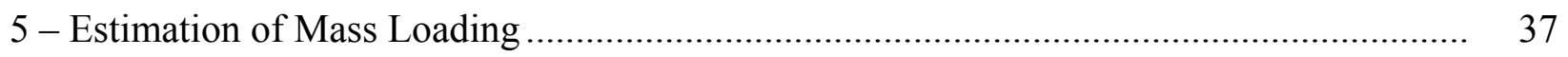

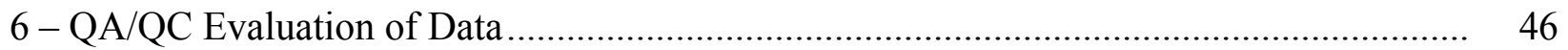

7 - Findings and Conclusions …………..................................................................... 49

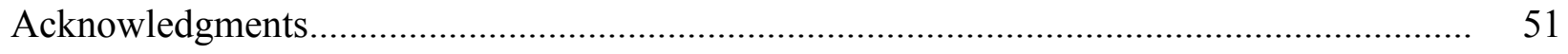

Appendix A - Sampling Instructions for Produced Water Study ............................................ 52

Appendix B - Sampling Log Sheet …………………................................................ 56

Appendix C - Chain-of-Custody Form ………………...................................................... 57

Appendix D - Sample Results ................................................................................ 58

Appendix E - MMS Data on Produced Water Production by Lease during 2003 .................. 65

\section{TABLES}

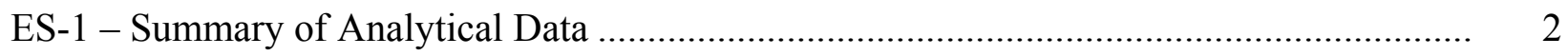

ES-2 - Loading Estimates for 50 Platforms and Entire Hypoxic Zone.................................... 2

1 - Analytical Methods Used in the Study ……………........................................................ 8

2 - Platforms Sampled Three Times............................................................................. 11

3 - Platforms Sampled One Time …………………......................................................... 12

4 - Hold Times and Preservative Requirements ................................................................ 13 


\section{TABLES (Cont.)}

5 - Platform Discharge Design and Location.....

6 - Variability in Water Production at 8 Gulf of Mexico Platforms over Many Months

7 - Discharge Volume Estimate for Sampled Platforms .............................................. 20

8 - Type of Hydrocarbon Produced at Sampled Platforms ............................................ 22

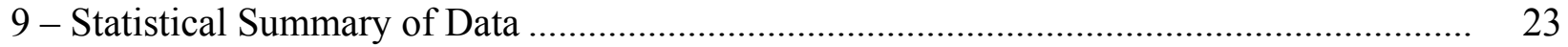

10 - Change in Statistical Properties after Removing BOD Outliers .................................. 26

11 - Change in Statistical Properties after Removing TOC Outliers .................................. 28

12 - Change in Statistical Properties after Removing Nitrate Outliers .............................. 29

13 - Change in Statistical Properties after Removing Orthophosphate Outliers................... 31

14 - Change in Statistical Properties after Removing Total Phosphorus Outliers ................. 33

15 - Linear Regression Correlations between Parameters .............................................. 35

16 - Average Concentrations Displayed by Type of Hydrocarbon Produced

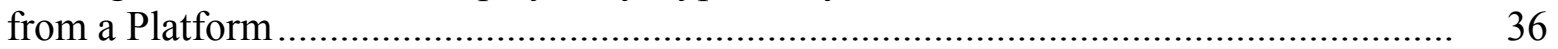

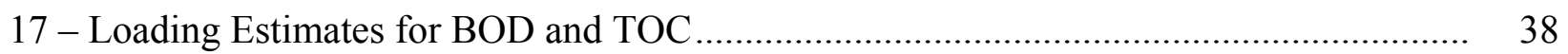

18 - Loading Estimates for Nitrate and Nitrite............................................................. 39

19 - Loading Estimates for Ammonia and TKN ..................................................... 40

20 - Loading Estimates for Orthophosphate and Total Phosphorus.................................... 42

21 - Extrapolation of Loading Estimates to Entire Hypoxic Zone.................................... 44

22 - Data on Depth of Discharge Locations ................................................................

23 - Comparison of Nutrient Loadings from Produced Water Discharges

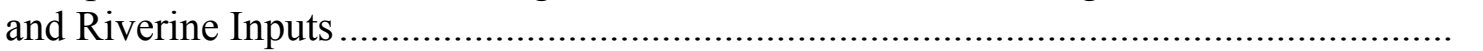




\section{FIGURES}

1 - Boundary of Hypoxic Zone during July 2004 Sampling Cruises ................................ 4

2 - Size of the Hypoxic Zone ............................................................................... 5

3 - General Permit Text Describing the Produced Water Hypoxia Study ............................ 6

4 - Location of Platforms in Sampling Study .........................................................

5 - Plot of BOD Results from All Platforms ............................................................ 25

6 - BOD Values by Lease Area ......................................................................... 26

7 - Plot of TOC Results from All Platforms.................................................................. 27

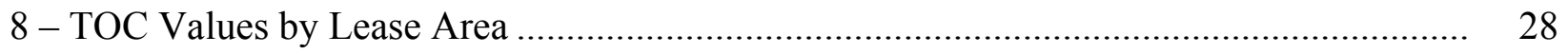

9 - Plot of Nitrate Results from All Platforms ......................................................... 29

10 - Nitrate Values by Lease Area .......................................................................... 30

11 - Plot of Orthophosphate Results from All Platforms ........................................... 31

12 - Orthophosphate Values by Lease Area ............................................................. 32

13 - Plot of Total Phosphorus Results from All Platforms ......................................... 33

14 - Total Phosphorus Values by Lease Area .............................................................. 34 


\section{Executive Summary}

Each summer, an area of low dissolved oxygen (the hypoxic zone) forms in the shallow nearshore Gulf of Mexico waters from the Mississippi River Delta westward to near the Texas/Louisiana border. Most scientists believe that the leading contributor to the hypoxic zone is input of nutrients (primarily nitrogen and phosphorus compounds) from the Mississippi and Atchafalaya Rivers. The nutrients stimulate growth of phytoplankton. As the phytoplankton subsequently die, they fall to the bottom waters where they are decomposed by microorganisms. The decomposition process consumes oxygen in the bottom waters to create hypoxic conditions.

Sources other than the two rivers mentioned above may also contribute significant quantities of oxygen-demanding pollutants. One very visible potential source is the hundreds of offshore oil and gas platforms located within or near the hypoxic zone. Many of these platforms discharge varying volumes of produced water. However, only limited data characterizing oxygen demand and nutrient concentration and loading from offshore produced water discharges have been collected. No comprehensive and coordinated oxygen demand data exist for produced water discharges in the Gulf of Mexico.

This report describes the results of a program to sample 50 offshore oil and gas platforms located within the Gulf of Mexico hypoxic zone. The program was conducted in response to a requirement in the U.S. Environmental Protection Agency (EPA) general National Pollutant Discharge Elimination System (NPDES) permit for offshore oil and gas discharges. EPA requested information on the amount of oxygen-demanding substances contained in the produced water discharges. This information is needed as inputs to several water quality models that EPA intends to run to estimate the relative contributions of the produced water discharges to the occurrence of the hypoxic zone.

Sixteen platforms were sampled 3 times each at approximately one-month intervals to give an estimate of temporal variability. An additional 34 platforms were sampled one time. The 50 sampled platforms were scattered throughout the hypoxic zone to give an estimate of spatial variability. Each platform was sampled for biochemical oxygen demand (BOD), total organic carbon (TOC), nitrogen (ammonia, nitrate, nitrite, and total Kjeldahl nitrogen [TKN]), and phosphorus (total phosphorus and orthophosphate). In addition to these parameters, each sample was monitored for $\mathrm{pH}$, conductivity, salinity, and temperature.

The sampling provided average platform concentrations for each parameter. Table ES-1 shows the mean, median, maximum, and minimum for the sampled parameters. For some of the parameters, the mean is considerably larger than the median, suggesting that one or a few data points are much higher than the rest of the points (outliers). Chapter 4 contains an extensive discussion of outliers and shows how the sample results change if outliers are deleted from consideration. 
Table ES-1 - Summary of Analytical Data

\begin{tabular}{|c|c|c|c|c|}
\hline Parameter & Mean & Median & Maximum & Minimum \\
\hline $\mathrm{BOD}, \mathrm{mg} / \mathrm{L}$ & 957 & 583 & 11,108 & 80 \\
\hline Dissolved BOD, mg/L & 498 & 432 & 1,128 & 132 \\
\hline Suspended BOD, mg/L & 76 & 57 & 146 & 16 \\
\hline $\mathrm{TOC}, \mathrm{mg} / \mathrm{L}$ & 564 & 261 & 4,880 & 26 \\
\hline Dissolved TOC, mg/L & 216 & 147 & 620 & 67 \\
\hline Suspended TOC, mg/L & 32 & 13 & 127 & 5 \\
\hline Nitrate, $\mathrm{mg} / \mathrm{L}$ & 2.15 & 1.15 & 15.80 & 0.60 \\
\hline Nitrite, $\mathrm{mg} / \mathrm{L}$ & 0.05 & 0.05 & 0.06 & 0.05 \\
\hline Ammonia, $\mathrm{mg} / \mathrm{L}$ & 74 & 74 & 246 & 14 \\
\hline TKN, mg/L & 83 & 81 & 216 & 17 \\
\hline Orthophosphate, mg/L & 0.43 & 0.14 & 6.60 & 0.10 \\
\hline Total phosphorus, mg/L & 0.71 & 0.28 & 7.90 & 0.10 \\
\hline Conductivity, $\mu \mathrm{mhos} / \mathrm{cm}$ & 87,452 & 86,480 & 165,000 & 360 \\
\hline Salinity, ppt & 100 & 84 & 251 & 0 \\
\hline Temperature, ${ }^{\circ} \mathrm{C}$ & 38 & 32 & 80 & 20 \\
\hline $\mathrm{pH}, \mathrm{SU}$ & 6.29 & 6.50 & 7.25 & 1.77 \\
\hline
\end{tabular}

A primary goal of this study is to estimate the mass loading (lb/day) of each of the oxygendemanding pollutants from the 50 platforms sampled in the study. Loading is calculated by multiplying concentrations by the discharge volume and then by a conversion factor to allow units to match. The loadings calculated in this study of 50 platforms represent a produced water discharge volume of about $176,000 \mathrm{bbl} /$ day. The total amount of produced water generated in the hypoxic zone during the year 2003 was estimated as 508,000 bbl/day. This volume is based on reports by operators to the Minerals Management Service each year. It reflects the volume of produced water that is generated from each lease, not the volume that is discharged from each platform. The mass loadings from offshore oil and gas discharges to the entire hypoxic zone were estimated by multiplying the 50-platform loadings by the ratio of total water generated to 50-platform discharge volume. The loadings estimated for the 50 platforms and for the entire hypoxic zone are shown in Table ES-2.

Table ES-2 - Loading Estimates for 50 Platforms and Entire Hypoxic Zone

\begin{tabular}{|l|c|c|}
\hline Parameter & $\begin{array}{c}\text { Loading from Sampled } \\
\text { Platforms (lb/day) }\end{array}$ & $\begin{array}{c}\text { Estimated Loading for Entire } \\
\text { Hypoxic Zone (lb/day) }\end{array}$ \\
\hline BOD & 36,000 & 104,00 \\
\hline TOC & 14,100 & 40,700 \\
\hline Nitrate & 68.3 & 197 \\
\hline Nitrite & 3.07 & 9 \\
\hline Ammonia & 4,770 & 13,800 \\
\hline TKN & 5,140 & 14,900 \\
\hline Orthophosphate & 22.6 & 65 \\
\hline Total phosphorus & 37.6 & 109 \\
\hline
\end{tabular}


These estimates and the sampling data from 50 platforms represent the most complete and comprehensive effort ever undertaken to characterize the amount and potential sources of the oxygen demand in offshore oil and gas produced water discharges.

Although these numbers appear large, they should be considered in the context of the volume of the hypoxic zone, which is estimated as being $17,000 \mathrm{~km}^{2}$ in area and an average of $17 \mathrm{~m}$ deep. This gives a hypoxic zone volume of $289 \mathrm{~km}^{3}\left(2.9 \times 10^{11} \mathrm{~m}^{3}\right.$, or $2.9 \times 10^{14}$ liters $)$. A discharge loading of $104,000 \mathrm{lb}$ of BOD, if assumed to be evenly diluted throughout the entire hypoxic zone, would contribute only $0.17 \mu \mathrm{g} / \mathrm{L}$, or $0.17 \mathrm{ppb}$, of additional BOD. The weight of all that water is an equally impressive number. Assuming a weight of $2.2 \mathrm{lb} / \mathrm{L}$ (this is the weight of fresh water - salt water is slightly heavier), this equals $6.4 \times 10^{14} \mathrm{lb}$.

It is also important to consider that offshore platforms discharge to open ocean environments that are subject to wind and wave action. Discharges that are made anywhere near the surface will receive abundant reoxygenation due to the natural processes. More than half of the platforms identified as discharging produced water to the hypoxic zone discharge at or above the surface of the ocean. About 93 percent of those platforms discharge in the top 20 feet of the water column. This should provide effective mitigation for some of the oxygen-demanding pollutants.

Another important point of perspective is a comparison of the produced water discharge mass loadings to the mass loading of key pollutants from the Mississippi and Atchafalaya Rivers. The produced water discharge loadings estimated for the entire hypoxic zone are several orders of magnitude smaller than those entering the Gulf of Mexico from the rivers. The total nitrogen loading is about 0.16 percent and the total phosphorus loading is about 0.013 percent of the nutrient loading coming from the Mississippi and Atchafalaya Rivers. 


\section{Chapter 1 - Introduction}

What Is the Hypoxic Zone?

Portions of the northern Gulf of Mexico experience low dissolved oxygen (hypoxia) each summer. A common criterion for hypoxia is a dissolved oxygen concentration of less than $2.0 \mathrm{mg} / \mathrm{L}$. The hypoxic zone in the Gulf of Mexico forms in warm months in the shallow nearshore waters from the Mississippi River Delta westward to near the Texas/Louisiana border. Figure 1 shows the approximate boundary of the hypoxic zone during cruises made in July 2004.

Figure 1 - Boundary of Hypoxic Zone during July 2004 Sampling Cruises

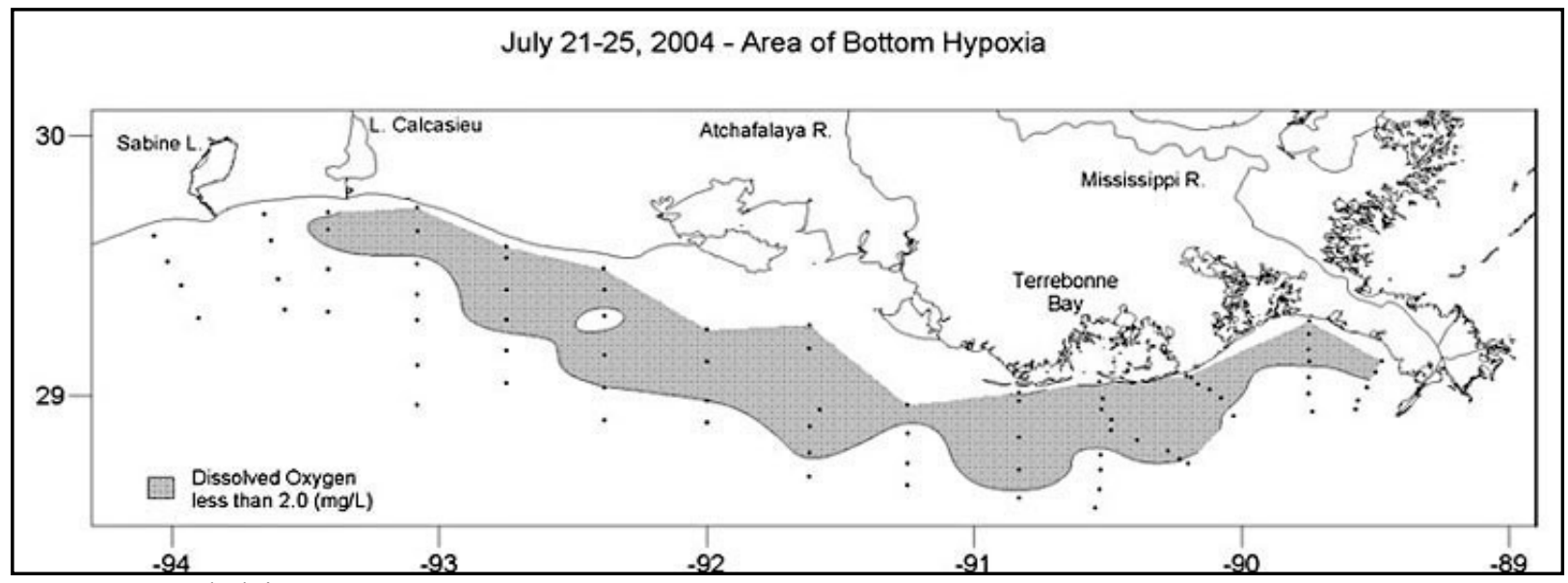

Source: N. Rabalais

Most scientists believe, and the weight of available evidence indicates, that the leading contributor to the hypoxic zone is input of nutrients from the Mississippi and Atchafalaya Rivers. The nutrients stimulate growth of phytoplankton. As the phytoplankton subsequently die, they fall to the bottom waters where they are decomposed by microorganisms. The decomposition process consumes most of the oxygen from the bottom waters to create hypoxic conditions.

The size of the hypoxic zone appears to be increasing over time. Rabalais and others have studied dissolved oxygen levels in this area for nearly 20 years. Figure 2 shows the size of the hypoxic zone by year. The figure shows that the average size from 1985 to 1992 was about $9,000 \mathrm{~km}^{2}$, while from 1993 to 2002 the average size rose to about $17,000 \mathrm{~km}^{2}$. Various factors contribute to the size of the hypoxic zone, including river flow (related to upstream rainfall and climate patterns), timing of rainfall in relation to fertilizer application, and changes in point and nonpoint source nutrient loads to the river systems. 
Figure 2 - Size of the Hypoxic Zone

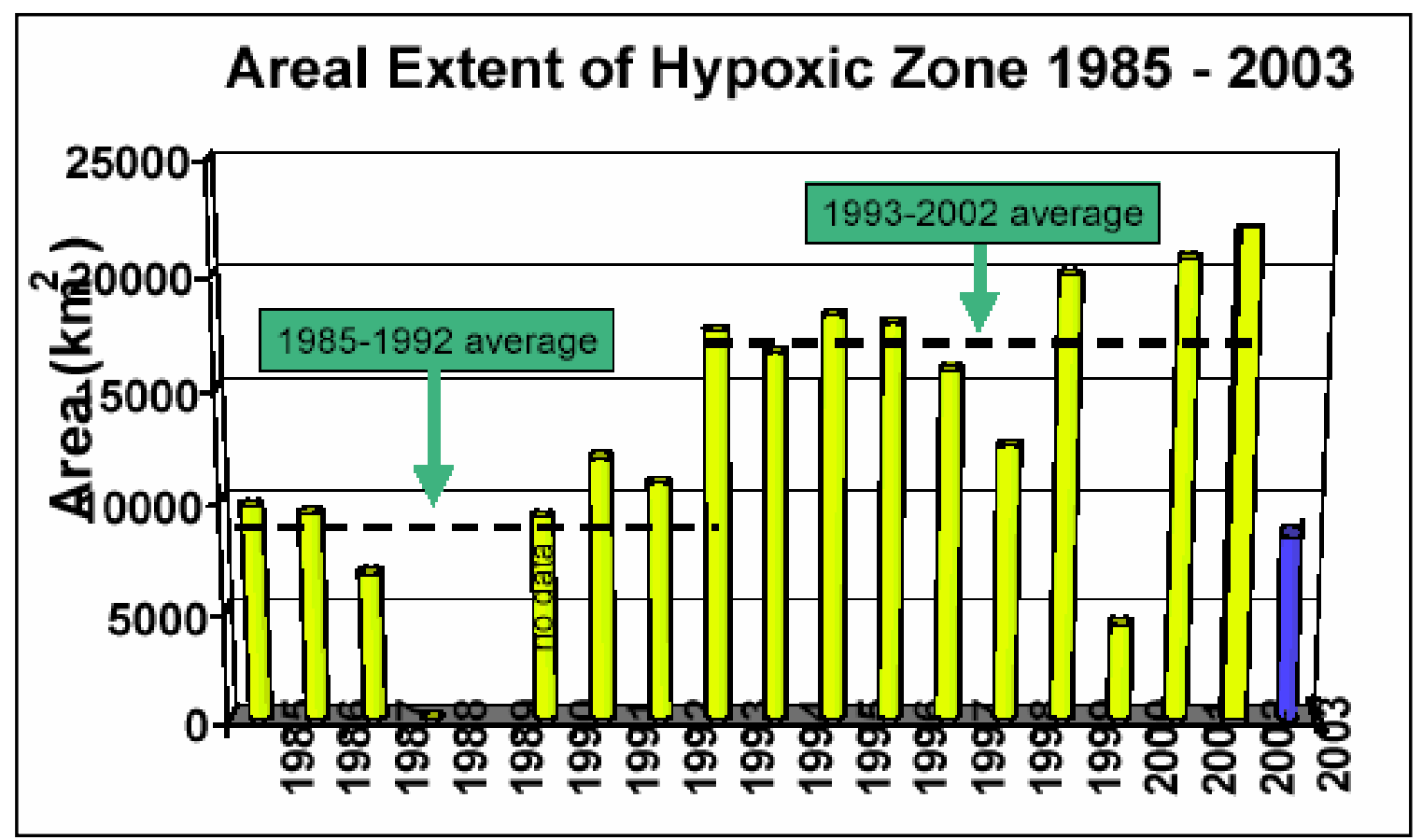

Source: N. Rabalais

The presence of hypoxic conditions is undesirable in that it creates an unfavorable habitat for most marine species, particularly those less mobile creatures living near or in the sea floor.

What Is the Issue?

Although the largest contributor to the hypoxic zone is believed to be nutrient inputs from the Mississippi and Atchafalaya Rivers, other sources may also contribute significant quantities of oxygen-demanding pollutants. One very visible potential source is the hundreds of offshore oil and gas platforms located within or near the hypoxic zone. Many of these platforms discharge varying volumes of produced water. Produced water is water trapped in underground formations that is brought to the surface along with oil or gas. Produced water characteristics and physical properties vary considerably depending on the geographic location of the field, the geological formation with which the produced water has been in contact for thousands of years, and the type of hydrocarbon product being produced. Produced water properties and volume can even vary throughout the lifetime of the reservoir.

Traditionally, offshore produced water discharges have been monitored for oil and grease, toxicity, and other parameters. However, only limited data characterizing oxygen demand and nutrient concentration and loading from offshore produced water discharges have ever been collected. No comprehensive and coordinated oxygen demand data exist for produced water discharges in the Gulf of Mexico or anywhere else in the world. The U.S. Environmental Protection Agency (EPA) wants to better understand the contribution that offshore discharges make to the hypoxic zone. The first step toward this goal is collection of oxygen-demand data from a representative sample of platforms. The direct oxygen demand is measured by the 5-day 
biochemical oxygen demand (BOD) and total organic carbon (TOC). The indirect oxygen demand is measured by the nutrients that stimulate phytoplankton growth - primarily nitrogen and phosphorus.

Concentration data can be combined with discharge volume data to make estimates of the mass loading of oxygen-demanding substances that are discharged within the hypoxic zone. Water quality models can use these data as inputs to estimate the contribution of the produced water discharges compared to the riverine and other sources.

\section{$\underline{\text { Basis for This Report }}$}

On October 7, 2004, EPA Region VI reissued National Pollutant Discharge Elimination System (NPDES) General Permit GMG 290000 for discharges from offshore oil and gas operations in the western portion of the Outer Continental Shelf of the Gulf of Mexico. The permit included a new requirement I. B. 4 (b) (v) for a study of produced water discharges to the hypoxic zone in the Gulf of Mexico (the permit language is displayed in Figure 3). The permit language notes that operators may conduct sampling for each platform individually or may comply with these monitoring requirements through participation in an EPA-approved industry-wide study. The industry, using the Offshore Operators Committee (OOC) as a focal point, elected to conduct the industry-wide study. This report contains the results of that study.

Figure 3 - General Permit Text Describing the Produced Water Hypoxia Study

Two options are available to meet this monitoring requirement. As described below, operators may either conduct the monitoring at each platform or they may participate in an industry wide study to meet the requirements. For the purposes of these monitoring requirements, the hypoxic zone is defined to include the following Minerals Management Service designated lease areas:

High Island blocks 36, 37, 47, 48, 86, 117, 118, 131, 132, A1, A2, A3, A4, A11, A12, A13, and A14; High Island East Addition blocks 38 through A180; Sabine Pass blocks 5 through 16; West Cameron blocks 154 through 356; West Cameron blocks 22 through 276, East Cameron blocks 10 through 190; Vermillion block 11 through 211; South Marsh Island North Addition blocks 208 through 288; South Marsh Island blocks 1 through 55; Eugene Island blocks 20 through 245, 113A, 113B, 128A, and 129A; Ship Shoal blocks 37 through 211; South Pelto blocks 1 through 25; South Timbalier blocks 7 through 182; Grand Isle blocks 16 through 63; and, West Delta blocks 16 through 101.

Operators discharging produced water from facilities located in the hypoxic zone of the northern Gulf of Mexico, as defined above, shall monitor those discharges for the oxygen demanding parameters and nutrients listed below. Operators shall also submit discharge design information to EPA to be used for analysis of the impacts of the discharges. Monitoring for oxygen demanding pollutants and nutrients shall consist of a minimum of six samples collected at a frequency of once per month. Oxygen Demanding Pollutants - Five-day Biological Oxygen Demand (BOD), Total Organic Carbon (TOC), Nutrients - Ammonia as N, nitrate + nitrite, Total Kjeldahl Nitrogen (TKN), Total phosphorous, and ortho-phosphate. In addition, operators shall provide a description of the outfall structure including the depth of the discharge point, the pipe diameter, the direction in which the discharge is oriented (i.e.: straight down, horizontally, etc.), and the total water depth at the discharge location.

Operators shall also provide an accurate measurement of the volume of produced water which is discharged from each platform located in the hypoxic zone. A report containing the results of these monitoring requirements shall be submitted to EPA Region 6 within nine (9) months after the effective date of this permit. Alternatively, operators may comply with these monitoring requirements through participation in an EPA approved industrywide study. That study may include a smaller, statistically representative number of discharging platforms. 


\section{Chapter 2 - Design and Scope of the Study}

EPA requires submittal of the results of the study within nine months of the effective date of the permit (by August 7, 2005). At the time the permit was issued (October 2004), no approved study plan existed. This abbreviated project schedule required a rapid start for the study. It was necessary to move forward expeditiously to develop a study plan that the industry supported; circulate it to EPA, the U.S. Department of Energy (DOE), and the U.S. Department of Interior's Minerals Management Service (MMS) for review and approval; identify the facilities that would be sampled; then commence an intensive sampling program so that sampling could be completed by the end of May 2005. The report was prepared during June 2005 and reviewed during July 2005 in order to meet the August 2005 deadline. This chapter describes the process used to develop the sampling plan, the elements of the plan, and provides a discussion of the data availability and logistical issues that impeded smooth implementation of the plan.

\section{What Events Led to the Study?}

During 2003, EPA had circulated an early draft of the general permit that included provisions that would have restricted any new or increased discharges of produced water to the hypoxic zone. The industry, DOE, and MMS objected to these conditions. EPA subsequently replaced this condition with a requirement to collect data on oxygen demand, and the industry and other agencies agreed to help fund studies to characterize the hypoxia problem. DOE's contribution provided funds to Argonne National Laboratory (Argonne) to organize and coordinate this produced water sampling study. Industry funded the analytical work and provided logistical support for the sampling program. MMS provided background data to Argonne and separately funded a white paper on the hypoxic zone. The draft permit was made available for review and comment in June 2004.

A series of meetings and conference calls occurred during the late summer and fall of 2004 that helped to focus the efforts for this study. Two meetings were held in August and September with representatives of the three lead agencies and industry. During the September meeting, the group heard presentations from several scientists about the types of water quality models that could be used to help EPA determine the impacts resulting from platform discharges. The scientists indicated the types of data that they would need from the produced water sampling study to serve as model inputs.

During these meetings, agreement was reached on the actual study area. Rabalais and her co-workers had collected data that showed the approximate boundaries of the Gulf of Mexico areas that experienced at least a 25 percent occurrence of summer hypoxia. These boundaries are shown in Figure 4, which is based on a map prepared by MMS. The lease block listed in the permit language (Figure 3) covers an area slightly larger than the 25 percent-hypoxia boundary. Figure 4 shows a few of the sampled platforms that are located just outside of the 25 percent hypoxia boundary.

The American Petroleum Institute (API) contracted a Louisiana laboratory, AccuLab, to provide analytical services for the study. In order to coordinate large numbers of samples coming from offshore to a series of shore bases, AccuLab partnered with another Louisiana laboratory, 
Environmental Enterprises, USA, which has an established sample collection and transportation system for offshore samples.

During the next few months, Argonne developed and obtained concurrence for the sampling plan. The details of the final plan are described in this chapter. EPA approved the sampling plan on February 2, 2005. Argonne, in conjunction with representatives from OOC and API, finalized selection of the platforms that would be sampled, notified those platforms operators, and began sampling in late February.

Late in 2004, the OOC established a Web-based registry so that its members and other offshore operators could enter information on their platforms that had discharges in the hypoxic zone. This registry was later used to select platforms to be sampled.

\section{Elements of the Sampling Plan}

What parameters should be sampled? The goal of the study is to better understand the direct and indirect oxygen demand associated with produced water. The direct oxygen demand was measured on all samples by BOD and TOC. To aid the modelers, in approximately 10 percent of the samples, separate tests were done to distinguish between the dissolved and particulate forms of oxygen-demanding materials (e.g., particulate BOD, dissolved BOD, dissolved organic carbon, and particulate organic carbon).

The indirect oxygen demand was measured by the nutrients that stimulate phytoplankton growth - nitrogen and phosphorus. For nitrogen, samples were tested for ammonia, nitrate, nitrite, and total Kjeldahl nitrogen (TKN). For phosphorus, samples were tested for total phosphorus and orthophosphate. In addition to these highlighted parameters, each sample was monitored for basic water quality parameters (e.g., $\mathrm{pH}$, conductivity, salinity, and temperature).

EPA's Methods for the Chemical Analysis of Water and Wastes was used to perform the required analyses. The parameters assayed and tests methods used in this study are shown in Table 1.

Table 1 - Analytical Methods Used in the Study

\begin{tabular}{|l|l|}
\hline \multicolumn{1}{|c|}{ Test Parameter } & \multicolumn{1}{c|}{ EPA Method } \\
\hline BOD & EPA Method 405.1 \\
\hline TOC & EPA Method 415.1 \\
\hline TKN & EPA Method 351.3 \\
\hline Ammonia & EPA Method 350.3 \\
\hline Nitrate & EPA Method 353.3 \\
\hline Nitrite & EPA Method 354.1 \\
\hline Orthophosphate & EPA Method 365.2 \\
\hline Total phosphorus & EPA Method 365.2 \\
\hline pH & EPA Method 150.1 \\
\hline Salinity & EPA Method 325.3 \\
\hline Conductivity & EPA Method 120.1 \\
\hline
\end{tabular}


What basis was used to select the sites? Neither EPA nor MMS has readily available information on the number of produced water discharges made to the study area. As an alternate approach, MMS data on those leases that generate (not discharge) produced water was used. MMS reported 496 leases in the study area that showed both production of oil and/or gas and water in 2003. It was not practical to sample the discharges in all of the leases, so a representative subset of about 10 percent of the leases was chosen. The study focuses on 50 sites located within a zone having at least a 25 percent occurrence of summer hypoxia based on average annual data from 1985 to 2002 (the $>25$ percent hypoxic zone). Figure 4 shows the $>25$ percent hypoxic zone boundary, the leases and lease blocks, and the locations of the 50 platforms selected for sampling.

\section{Figure 4 - Location of Platforms in Sampling Study}

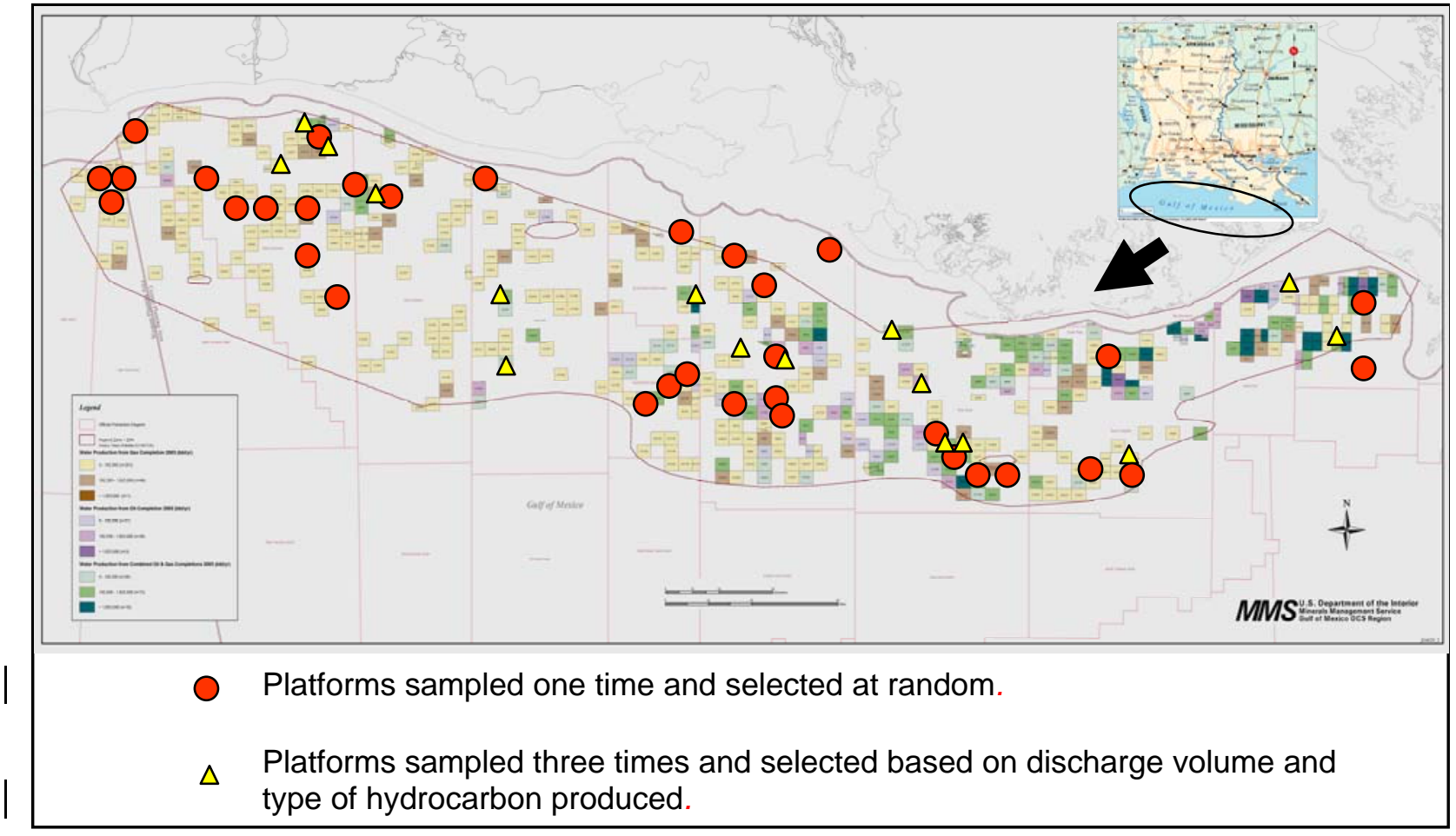

As shown in Figure 4, two of the platforms fall just outside of the $>25$ percent hypoxia boundary. This reflects the fact that the list of lease blocks in EPA's permit language (Figure 3) covers an area slightly larger than the $>25$ percent hypoxia boundaries. Nevertheless, these platforms are very close to the boundary and could potentially influence conditions inside the boundary.

A hybrid sampling approach was followed to meet EPA's goals of large enough sample size, an estimate of temporal variability, and completion of the sampling program in a short time frame. Sixteen sites were scheduled for sampling three times each at about one-month intervals, and an additional 34 sites were scheduled to be sampled once. One of the 16 platforms stopped producing water before the third sample was collected, so only two samples were available at that location. The sites to be sampled once were selected at random, while the sites to be 
sampled three times were selected using the following criteria to ensure a range of different production and discharge conditions.

The produced water generation rate. Produced water discharge composition may vary between platforms having different volumes of discharge. Platforms with large discharges may use different types of treatment processes than platforms with smaller discharges. To evaluate the effect of produced water volume, the produced water generation rate by lease was tentatively subdivided into three classes: low production $(<500 \mathrm{bbl} /$ day $)$, medium production (500 to $5,000 \mathrm{bbl} /$ day $)$, and high production $(>5,000 \mathrm{bbl} /$ day $)$. Generation rates were initially determined using MMS records for 2003, but were later refined by obtaining actual discharge data from the selected operators.

The nature of the hydrocarbon that is produced on the lease generating the produced water. Produced water associated with gas production may have different chemical composition than produced water from oil wells. Hydrocarbon production is subdivided into three classes: leases having wells with $>90$ percent oil completions, leases having wells with $>90$ percent gas completions, and leases having wells with both oil and gas completions (i.e., from 10 percent to 90 percent oil completions). This type of subdivision also leads to wide geographic coverage of selected sites throughout the hypoxic zone. Wells in the eastern portion of the MMS Central Planning Area of the Gulf of Mexico tend to produce more oil, while those in the western Gulf produce more gas.

Subdividing by these two factors results in 9 categories. Representative leases were selected from 8 of the 9 categories (generally among the highest 5 water-producing leases in each category). No platforms fell into the high water production/gas category. This is not surprising because, in general, gas wells do not produce as much water as oil wells. Sixteen leases operated by 6 different companies were selected (Table 2). The operators were contacted to verify their information and to identify which platform on the lease would be sampled.

For the other 34 platforms to be sampled once, leases were randomly selected from a list of platforms entered into the OOC hypoxia study registry. From the full list of platforms, platforms or leases that had already been sampled for the three-time sampling program were deleted. A short list was developed by randomly selecting 50 sites from the list. The first 34 platforms were selected and then contacted. Several of the platforms were not producing any water during the short time window that the sampling program needed to follow. These were replaced by the next platform in order from the list of 50. The final list of one-time sampled platforms is shown in Table 3. The 50 platforms represent 22 different companies and are located in 10 different lease areas. 
Table 2 - Platforms Sampled Three Times

\begin{tabular}{|l|l|}
\hline Platform $^{\mathbf{a}}$ & Operator \\
\hline EC 47JP & Newfield \\
\hline EI 107A & Apache \\
\hline EI 95F & W\&T Offshore \\
\hline GI 19\#3 & ExxonMobil \\
\hline SM 268A & Apache \\
\hline SS 108D & ChevronTexaco \\
\hline SS 169C & ChevronTexaco \\
\hline SS 182C & ChevronTexaco \\
\hline SS 58A & Newfield \\
\hline ST 148E & Newfield \\
\hline VR 164A & ExxonMobil \\
\hline VR1 19D & W\&T Offshore \\
\hline WC 102G & BP \\
\hline WC 110A & BP \\
\hline WC 65JA & BP \\
\hline WD 73A & ExxonMobil \\
\hline
\end{tabular}

${ }^{\mathrm{a}}$ The two-letter abbreviations are used by MMS for its lease areas. Each lease area is subdivided into a series of numbered blocks, which are typically three miles by three miles in size. Not each lease block has a platform; however, if there is more than one platform or structure on a lease block, each structure is given an ID, usually a letter designator. For example, SS 182C is platform C on block 182 of the Ship Shoal lease area.

How much variability is acceptable between the three samples taken at each of the 16 platforms? Before starting the sampling, the project participants agreed that at the end of the three-time sampling program, Argonne would evaluate the BOD results at each platform using a variability criterion. The criterion proposed by Argonne and approved by EPA is a coefficient of variation (CV) of 0.6 or lower. The CV is defined as the standard deviation divided by the mean. EPA has based much of its water quality control program on the 1991 Technical Support Document for Water Quality-Based Toxics Control (TSD). On page 107 of the TSD, EPA states: "EPA recommends a value of 0.6 as a default $\mathrm{CV}$, if the regulatory authority does not have more accurate information on the $\mathrm{CV}$ for the pollutant or pollutant parameter." This same general principle is embodied in the November 2004 draft National Whole Effluent Toxicity (WET) Implementation Guidance Under the NPDES Program, which recommends the use of CV $=0.6$ for sample sizes of less than 10 .

After the third sample was collected from a platform, the mean, standard deviation, and CV were calculated for each platform. If the first three samples exceed the variability criterion, a fourth sample is taken and the variability is checked again. If the data meet the variability criterion, sampling stops. If the data do not meet the variability criteria, a fifth sample is taken. The same procedure is used following the fifth sample to determine if a sixth sample if necessary. 


\section{Table 3 - Platforms Sampled One Time}

\begin{tabular}{|c|c|}
\hline Lease Area, Block, and Platform ID & Operator \\
\hline EC 46B & Stone Energy Corporation \\
\hline EC 49B & Newfield Exploration Company \\
\hline EI 128A-JC & Energy Resource Technology, Inc. \\
\hline EI 172A & Newfield Exploration Company \\
\hline EI 175B & Apache \\
\hline EI 184A & Newfield Exploration Company \\
\hline EI 50-1 & Hunt Petroleum (AEC), Inc. \\
\hline EI 57A & Northstar Gulfsand, LLC \\
\hline EI 74A & Chevron U.S.A. Inc. \\
\hline HI 37A & Seneca Resources Corporation \\
\hline HI 39A & The Houston Exploration Company \\
\hline HI 46A & Mariner Energy, Inc. \\
\hline SM 238-190 & El Paso Production GOM Inc \\
\hline SM 23G & Devon Energy Production Company L.P. \\
\hline SM 33D & Apache \\
\hline SM 40 JA & Hunt Petroleum (AEC), Inc. \\
\hline SS 157A & Newfield Exploration Company \\
\hline SS 182E & Chevron U.S.A. Inc. \\
\hline SS 189A & Apache \\
\hline SS $191 \mathrm{~B}$ & Hunt Petroleum (AEC), Inc. \\
\hline ST 161A & Apache \\
\hline ST 164C & Stone Energy Corporation \\
\hline ST 34A & Bois d'Arc Offshore Ltd \\
\hline VR 22B & Energy Resource Technology, Inc. \\
\hline WC 130A & Dominion Exploration \& Production, Inc. \\
\hline WC 168A & Linder Oil Company, A Partnership \\
\hline WC 170A & Nexen Petroleum \\
\hline WC $173 \mathrm{~K}$ & The Houston Exploration Company \\
\hline WC $215 \mathrm{~A}$ & Energy Resource Technology, Inc. \\
\hline WC 237A & ATP Oil \& Gas Corporation \\
\hline WC 53A & El Paso Production \\
\hline WC 71D & BP Exploration \& Production Inc. \\
\hline WD 45A & Nexen Petroleum USA Inc. \\
\hline WD 89A & Eni Petroleum Co. Inc. \\
\hline
\end{tabular}

Who collected the samples and how did they get transported to the laboratory? The samples were collected by the operators of each selected offshore platform. Environmental Enterprises USA (EEUSA) prepared the sample kits, with sample bottles, preservatives where needed, a thermometer, sampling instructions (Appendix A), a sampling log sheet (Appendix B), and a chain-of-custody form (Appendix C). EEUSA scheduled the sample dates with each operator. 
The sample kits were delivered by an EEUSA courier to the shore bases used by each company several days in advance of the sampling date.

The operators transported the sample kits to the platforms by helicopter or work boat. On the scheduled sampling date, the operators collected the samples (they had been instructed to first let the produced water sampling outlet on each platform run for several minutes to remove standing water), packaged them on ice in a cooler, and passed them over to helicopter pilots or workboat staff to bring to the shore base. Most samples were picked up from the shore bases by the EEUSA courier on the same day or the day following sampling and were driven to AccuLab. In a few cases, the samples were sent to AccuLab by overnight delivery services or by local courier services. The transportation needed to be closely coordinated because several of the analytical methods used required that the tests be started no later than 48 hours following sample collection.

Although sampling was fairly simple, the logistics involved were quite complicated, considering the offshore location of the sampling points, the distance to the laboratory, and preservation requirements/hold times associated with several of the analytical parameters. Table 4 indicates the maximum sample hold times and preservative requirements for each parameter.

Table 4 - Hold Times and Preservative Requirements

\begin{tabular}{|c|c|c|}
\hline Test Parameter & $\begin{array}{c}\text { Hold Time (from date } \\
\text { and time of sample } \\
\text { collection) }\end{array}$ & Preservative Requirements \\
\hline BOD & 48 hours & Cool, $<4^{\circ} \mathrm{C}$ \\
\hline TOC & 28 days & $\mathrm{H}_{2} \mathrm{SO}_{4}$ to $\mathrm{pH}<2 ; \mathrm{Cool},<4^{\circ} \mathrm{C}$ \\
\hline TKN & 28 days & $\mathrm{H}_{2} \mathrm{SO}_{4}$ to $\mathrm{pH}<2 ; \mathrm{Cool},<4^{\circ} \mathrm{C}$ \\
\hline Ammonia & 28 days & $\mathrm{H}_{2} \mathrm{SO}_{4}$ to $\mathrm{pH}<2 ; \mathrm{Cool},<4^{\circ} \mathrm{C}$ \\
\hline Nitrate & 48 hours & Cool, $<4^{\circ} \mathrm{C}$ \\
\hline Nitrite & 48 hours & Cool, $<4^{\circ} \mathrm{C}$ \\
\hline Orthophosphate & 48 hours & Cool, $<4^{\circ} \mathrm{C}$ \\
\hline Total phosphorus & 28 days & $\mathrm{H}_{2} \mathrm{SO}_{4}$ to $\mathrm{pH}<2 ; \mathrm{Cool},<4^{\circ} \mathrm{C}$ \\
\hline $\mathrm{pH}$ & 15 minutes & None required \\
\hline Salinity & 28 days & None required \\
\hline Conductivity & 28 days & Cool, $<4^{\circ} \mathrm{C}$ \\
\hline
\end{tabular}

What type of quality assurance/quality control (QA/QC) measures were included in the study design? Argonne, in conjunction with API, OOC, EEUSA, and AccuLab, developed sample collection and handling instructions, a chain-of-custody form, and a sampling log sheet. These are included as Appendices A, B, and C, respectively. The study included two types of field controls: field blanks and field duplicates. In order to validate field activities, the sampling program included field blanks for about 25 percent of the samples. The purpose of the field blank is to assess the possible impact of the sampling and transportation process on the quality of data collected. If any blank test result is above the maximum quantitation level (MQL) for any test parameter in the field blank, the reason is typically investigated and appropriate corrective 
action is taken as soon as possible, particularly if multiple blanks systematically show the same type and level of contamination.

Field duplicates were collected for about 10 percent of the samples. A field duplicate is a sample collected at the same time and under the same conditions as an actual sample. The purpose of field duplicate samples is to assess precision and the variability of the discharge stream. If a pair of duplicate samples exhibits a relative percent difference (RPD) of greater than 25 percent, investigation of the cause and documentation of the findings are considered, particularly if multiple duplicates consistently demonstrate high RPDs for the same parameter.

AccuLab has its own laboratory QA/QC program for ensuring that samples are received and handled correctly, and that instruments are calibrated. At the time of laboratory receipt, technicians log-in the samples, verify chain-of-custody information against the sample bottles, check for sample integrity (leaking, broken bottles, or improper preservation, etc.), and measure the temperature of the coolers to ensure that the samples were $<4^{\circ} \mathrm{C}$. If samples had not had sufficient time to cool prior to arrival, the presence of ice in the container in which the samples arrive was interpreted as evidence that the chilling process had begun. Sample temperature is particularly important for the BOD measurement, given that the rate of biodegradation will increase with increasing temperatures. The $\mathrm{pH}$ of samples preserved with acid or base was also checked.

Discrepancies during sample receipt are noted on AccuLab's Sample Receipt Checklist form and also on AccuLab's Sample Problems Fax Back form. The latter form identifies problems with a sample or a shipment of samples and allows the client two options: 1) discard samples, or 2) proceed with analysis with the understanding that any discrepancies might be flagged on the laboratory report. After discrepancies are resolved, the samples are logged into the Laboratory Information Management System (LIMS) and processing begins.

Prior to analysis, individual instruments required for each analysis were calibrated in accordance with manufacturers' instructions as well as laboratory-specific standard operating procedures (SOPs). This includes initial calibration as well as continuing calibration verification. Recalibrations are performed as necessary. Analyses were then performed in accordance with method requirements and laboratory SOPs. Laboratory QC samples consisted of the following:

Laboratory Reagent Blanks (LRB): These are also called method blanks. An LRB is a sample of deionized water and is analyzed as an actual sample. They are used to show the analysis process to be free of contamination. An LRB is analyzed with every batch of samples (a batch of samples is 20 or fewer samples analyzed within a 24-hour period). Sample analyses do not begin until the LRB result is below the MQL for the analyte tested. An exception is made for BOD. If the oxygen depletion of the unseeded dilution water is greater than $0.2 \mathrm{mg} / \mathrm{L}$, the BOD result is flagged. In this case, the data point is treated as estimated rather than as a definitive data point.

Laboratory Control Sample (LCS): These are also called laboratory-fortified blanks. An LCS is prepared by adding a known amount of analyte to deionized water. The LCS is analyzed as an actual sample. They are used to assess accuracy 
and to assure that the method and techniques used are capable of producing data of acceptable quality. An LCS is analyzed with every batch of samples. In general and in the absence of method-specific guidance, the acceptance limits for LCS recovery is 80-120 percent of the LCS true value. If the recovery of an LCS is outside of the acceptance range, sample analysis is halted until the cause is determined and corrected. Samples associated with a defective LCS are reanalyzed if possible. In the case of BOD, where reanalysis is generally not possible due to hold times, the results for samples associated with the defective LCS are flagged.

Matrix Spike (MS) Sample: An MS sample is prepared by adding a known amount of analyte to an actual sample. The MS is analyzed as an actual sample. MSs are used to assess the effect of sample matrix on a particular analysis. An MS is analyzed with every batch of samples. Given that samples from different projects are often combined to form a batch, it is possible that some MS samples may represent a different client or project. The laboratory indicated that it would strive to include MS samples from the produced water study as part of the batch QC. In general and in the absence of method-specific guidance, the acceptance limits for MS recovery is 80-120 percent of the spike concentration. If recovery is outside the acceptance limits and the LCS recovery is within limits, the results associated with the out-of-range MS are flagged. Note that the nature of the BOD test precludes the analysis of spiked samples.

Matrix Spike Duplicate (MSD) Sample: An MSD sample is prepared and analyzed in exactly the same manner as an MS sample. MSD samples are used to assess the precision of an analysis and naturally take matrix effects into account. An MSD is analyzed concurrently with the MS. In general and in the absence of method-specific guidance, the acceptance limits for MS/MSD is $\leq 25$ percent RPD. If the RPD of an MS/MSD pair is $>25$ percent, the associated results are flagged. For BOD, the LCS is analyzed in duplicate (a laboratory control sample duplicate, or LCSD) and serves as the precision assessment for the method.

What logistical and policy issues created extra challenges? Several features of this sampling program presented challenges above and beyond the normal complicating factors of field work. The first issue was the compressed time table. EPA required that the report be completed and submitted within nine months of the effective date of the permit. This is much shorter than normally used to design and conduct a study of this magnitude.

A second important issue is the remote locations of the platforms and the shore bases and the need to coordinate several transportation legs and still meet maximum sample holding times. Sample delivery relied heavily on helicopters. Particularly in the early weeks of the sampling, the Gulf of Mexico experienced many foggy days, and planned sampling dates needed to be rescheduled.

Another important factor is the presence of numerous project participants. The study plan had to be reviewed and approved by three agencies and by industry (through the OOC) before it could 
be implemented. This process required several iterations of review and revision of the sampling plan.

Ideally, sampling for all platforms would have been done by the same person or teams of people. This was not possible for this study due to logistical concerns and related costs. Once the sampling began, it was necessary to involve personnel from many different oil and gas companies. Often a company's permitting point of contact was not the person who does the field sampling, so there was a need to answer questions and educate many persons about the importance and details of the study. Further, there were many intermediate steps in the chain of custody, such as helicopter pilots and shore base managers.

Scheduling presented a major challenge. Quite a few of the original sampling dates needed to be postponed for a few days because of bad weather, maintenance on platform equipment, or other reasons. The EEUSA courier has a fixed weekly shore base visitation schedule. With the large number of delays, samples often came to shore on days other than the regularly scheduled collection days. The EEUSA scheduling coordinator worked very diligently to reschedule all samples within the sample holding time window.

Several platforms were producing water when the schedule was developed, but on the scheduled sampling date no water was being produced. These needed to be rescheduled or other platforms sampled, when the water production was not likely to resume soon. One of the platforms that was scheduled for three-time sampling was sampled on the first two dates as planned. By the time its third sampling date came around, the platform had stopped producing water and was not anticipated to resume production any time soon. Because the sampling cycle was so far along, only two samples were collected at that platform. 


\section{Chapter 3 - Description of Platforms Selected for Sampling}

This chapter provides several types of information about the 16 platforms selected for three-time sampling and the 34 platforms selected for one-time sampling. This information is included to meet the general permit requirements and to serve as reference information for the water quality models that are scheduled to be run.

\section{Platform Location and Discharge Configuration}

The general permit language requires submission of information about the discharge design of each of the tested platforms. That information and the latitude and longitude of each platform are included in Table 5.

Table 5 - Platform Discharge Design and Location

\begin{tabular}{|c|c|c|c|c|c|c|c|}
\hline Platform & $\begin{array}{c}\text { Water } \\
\text { Depth (ft) }\end{array}$ & $\begin{array}{l}\text { Discharge Depth } \\
\text { (ft below surface) }\end{array}$ & $\begin{array}{l}\text { Pipe Diameter } \\
\text { (in.) }\end{array}$ & $\begin{array}{c}\text { Pipe } \\
\text { Orientation }\end{array}$ & Diffuser & Latitude & Longitude \\
\hline EC 46B & 45 & 6 & 6 & Vertical down & None & 29.446784 & -92.971174 \\
\hline EC 47JP & 50 & 6 & 6 & Vertical down & None & 29.440641 & -92.977681 \\
\hline EC 49B & 50 & 0 & 4 & Vertical down & None & 29.414894 & -92.899125 \\
\hline El 107A & 25 & 5 & 4 & Vertical down & None & 29.026494 & -91.527274 \\
\hline El 128A-JC & 55 & 2 & 6 & Vertical down & None & 28.94315 & -91.609364 \\
\hline El 172A & 78 & 10 & 4 & Vertical down & None & 28.786711 & -91.589594 \\
\hline El 175B & 67 & 5 & 8 & Down & None & 28.790828 & -91.731624 \\
\hline El 184A & 88 & 70 & 6 & Vertical down & None & 28.732422 & -91.607955 \\
\hline El 50-1 & 23 & 0 & 4 & Vertical down & None & 29.2313717 & -91.75488895 \\
\hline EI 57A & 8 & 10 & 4 & Vertical down & None & 29.244395 & -91.386834 \\
\hline El 74A & 18 & 0 & 4 & Vertical down & None & 29.140763 & -91.63893 \\
\hline El 95F & 17 & 2' above & 8 & Vertical down & None & 29.08748886 & -91.6988907 \\
\hline GI 19\#3 & 55 & 41 & 12 & Up & Yes $^{a}$ & 29.149858 & -89.897425 \\
\hline HI 37A & 40 & 0 & 6 & Vertical down & None & 29.46958595 & -93.90923728 \\
\hline HI 39A & 35 & 0 & 6 & Vertical down & None & 29.478029 & -93.796791 \\
\hline $\mathrm{HI} 46 \mathrm{~A}$ & 30 & 0 & 4 & Vertical down & None & 29.42128298 & -93.84003778 \\
\hline SM 238-190 & 10 & 4 & 8 & Horizontal & None & 29.32831734 & -91.88724812 \\
\hline SM 23G & 81 & 8 & 4 & Vertical down & None & 28.86716564 & -91.89783564 \\
\hline SM 268A & 30 & 10 & 6 & Vertical down & None & 29.115855 & -91.871104 \\
\hline SM 33D & 85 & 0 & 4 & Down & None & 28.827329 & -91.947355 \\
\hline SM $40 \mathrm{JA}$ & 97 & 6 & 6 & Vertical down & None & 28.80942007 & -92.05837548 \\
\hline SS 108D & 25 & 0 & 18 & Vertical down & None $^{b}$ & 28.859204 & -91.131668 \\
\hline SS 157A & 52 & 0 & 6 & Vertical down & None & 28.67438498 & -91.08369876 \\
\hline SS 169C & 60 & 32 & 6 & Vertical down & Yes $^{c}$ & 28.644791 & -91.026014 \\
\hline SS 182C & 65 & 1 & 6 & Vertical down & None & 28.618316 & -90.994974 \\
\hline SS 182E & 65 & 18 & 6 & Vertical down & Yes $^{d}$ & 28.619125 & -90.994825 \\
\hline SS 189A & 85 & 0 & 6 & Down & None & 28.564446 & -90.803085 \\
\hline SS $191 \mathrm{~B}$ & 72 & 0 & 4 & Vertical down & None & 28.58814302 & -90.90229214 \\
\hline SS 58A & 20 & 0 & 3 & Vertical down & None & 28.982503 & -91.218691 \\
\hline ST 148E & 96 & 2 & 4 & Vertical down & None & 28.58847484 & -90.42093781 \\
\hline ST 161A & 125 & 0 & 4 & Vertical down & None & 28.569312 & -90.408951 \\
\hline ST $164 C$ & 100 & 0 & 8 & Vertical down & None & 28.56943 & -90.545117 \\
\hline ST 34A & 50 & 5 & 6 & Vertical down & None & 28.914125 & -90.486815 \\
\hline VR 164A & 95 & 77 & 8 & Vertical down & None & 28.902763 & -92.488892 \\
\hline
\end{tabular}




\begin{tabular}{|l|c|c|c|c|c|c|c|}
\hline Platform & $\begin{array}{c}\text { Water } \\
\text { Depth (ft) }\end{array}$ & $\begin{array}{c}\text { Discharge Depth } \\
\text { ft below surface) }\end{array}$ & $\begin{array}{c}\text { Pipe Diameter } \\
\text { (in.) }\end{array}$ & $\begin{array}{c}\text { Pipe } \\
\text { Orientation }\end{array}$ & Diffuser & Latitude & Longitude \\
\hline VR 22B & 38 & 0 & 4 & Vertical down & None & 29.469399 & -92.549909 \\
\hline VR119D & 68 & 5 above & 4 & Vertical down & None & 29.12059 & -92.502505 \\
\hline WC 102G & 42 & 0 & 4 & Vertical down & None & 29.559159 & -93.14566 \\
\hline WC 110A & 40 & 6 & 4 & Vertical down & None & 29.518285 & -93.284358 \\
\hline WC 130A & 40 & 8 & 2 & Vertical down & None & 29.48589141 & -93.5109452 \\
\hline WC 168A & 43 & 10 & 6 & Vertical down & None & 29.407099 & -93.404965 \\
\hline WC 170A & 40 & 6 & 6 & Vertical down & None & 29.400442 & -93.331788 \\
\hline WC 173K & 60 & 10 & 2 & Vertical down & None & 29.39874631 & -93.17797896 \\
\hline WC 215A & 60 & 6 & 6 & Vertical down & None & 29.243337 & -93.178322 \\
\hline WC 237A & 110 & 30 & 4 & Vertical down & None & 29.107708 & -93.085114 \\
\hline WC 53A & 35 & 10 & 2 & Horizontal & None & 29.624477 & -93.750615 \\
\hline WC 65JA & 36 & 10 & 4 & Vertical down & None & 29.627548 & -93.172415 \\
\hline WC 71D & 38 & 0 & 4 & Vertical down & None & 29.592809 & -93.148724 \\
\hline WD 45A & 45 & 5 & 4 & Vertical down & None & 29.10861 & -89.643752 \\
\hline WD 73A & 168 & 36 & 8 & Vertical down & Yes & 28.946315 & -89.706342 \\
\hline WD 89A & 200 & 10 & 7 & Vertical down & None & 28.901085 & -89.614413 \\
\hline
\end{tabular}

a The 12" downcomer departing the platform runs to 3 ' below the sea floor, where it is extended horizontally, then turned upward to provide for three 6" discharge ports located at least 100 meters apart.

${ }^{\mathrm{b}}$ Vertically split pipe with 2 ports, one above the water and one below, separated by 25 '.

' 2 ports separated by 22 '.

'Ports separated vertically by 22 '.

${ }^{\mathrm{e}}$ Consists of a vertical 8" pipe with an 8" discharge port (50 percent flow discharged horizontally to pipe) at 8 ' below the sea surface and a second 8" discharge point at the end of the pipe (discharging down toward the seafloor with 50 percent flow) located 36' below the sea surface.

\section{Produced Water Discharge Volume}

The general permit language also requires submission of information about the discharge volume of each of the tested platforms. Specifically: "Operators shall also provide an accurate measurement of the volume of produced water which is discharged from each platform located in the hypoxic zone." Some platforms have relatively consistent discharge volume while others fluctuate a great deal. Most discharges are composites of produced water from numerous wells from one or more platforms. The individual wells may be completed in different formations with different water production rates. Over time, some wells go out of service and other ones come online. All of these factors contribute variability to discharge volumes and characteristics.

Table 6 shows the monthly discharge volumes from eight platforms that discharge into the hypoxic zone. Several of these are part of the group of 50 sampled platforms. Data are presented by month for three years for three of the platforms and for one year for five of the platforms. The statistical features include mean, standard deviation, minimum, and maximum. It is apparent that volumes are not consistent at most of these platforms. For the purposes of this report, we used the average value to characterize the flow for these platforms. Nevertheless, readers should recognize that discharge volumes fluctuate substantially over time. 
Table 6 - Variability in Water Production at 8 Gulf of Mexico Platforms over Many Months

\begin{tabular}{|c|c|c|c|c|c|c|c|c|}
\hline \multirow[t]{2}{*}{ Month } & \multicolumn{8}{|c|}{ Discharge Volume (bbl/day) from Platforms Identified Below } \\
\hline & A & B & C & $\mathrm{D}$ & $\mathrm{E}$ & $\mathrm{F}$ & G & $\mathrm{H}$ \\
\hline Apr-03 & 20,632 & 77 & 56,140 & No data & No data & No data & No data & No data \\
\hline May-03 & 18,603 & 94 & 58,075 & No data & No data & No data & No data & No data \\
\hline Jun-03 & 21,610 & 101 & 62,330 & No data & No data & No data & No data & No data \\
\hline Jul-03 & 20,913 & 69 & 65,173 & No data & No data & No data & No data & No data \\
\hline Aug-03 & 17,214 & 127 & 68,788 & No data & No data & No data & No data & No data \\
\hline Sep-03 & 16,679 & 125 & 70,525 & No data & No data & No data & No data & No data \\
\hline Oct-03 & 16,048 & 78 & 71,252 & No data & No data & No data & No data & No data \\
\hline Nov-03 & 17,095 & 84 & 70,376 & No data & No data & No data & No data & No data \\
\hline Dec-03 & 18,000 & 87 & 70,468 & No data & No data & No data & No data & No data \\
\hline Jan-04 & 19,238 & 90 & 49,021 & No data & No data & No data & No data & No data \\
\hline Feb-04 & 20,071 & 110 & 61,527 & No data & No data & No data & No data & No data \\
\hline Mar-04 & 19,857 & 67 & 69,799 & No data & No data & No data & No data & No data \\
\hline Apr-04 & 19,996 & 36 & 68,568 & No data & No data & No data & No data & No data \\
\hline May-04 & 20,697 & 57 & 63,544 & No data & No data & No data & No data & No data \\
\hline Jun-04 & 20,862 & 96 & 63,008 & No data & No data & No data & No data & No data \\
\hline Jul-04 & 18,774 & 2 & 66,642 & 7,750 & 34,809 & 32,000 & 30,655 & 9,547 \\
\hline Aug-04 & 19,983 & 71 & 66,085 & 8,000 & 32,358 & 33,000 & 30,495 & 9,624 \\
\hline Sep-04 & 19,057 & 157 & 53,503 & 9,584 & 33,358 & 25,880 & 15,332 & 10,287 \\
\hline Oct-04 & 26,442 & 246 & 63,244 & 9,869 & 32,780 & 28,000 & 16,386 & 10,509 \\
\hline Nov-04 & 22,560 & 528 & 60,931 & 9,591 & 34,811 & 30,000 & 5,306 & 795 \\
\hline Dec-04 & 22,618 & 856 & 63,038 & 9,100 & 32,032 & 26,151 & 4,344 & 8,641 \\
\hline Jan-05 & 22,911 & 921 & 61,309 & 8,450 & 35,106 & 26,400 & 25,236 & 8,750 \\
\hline Feb-05 & 19,297 & 522 & 64,200 & 6,440 & 35,600 & 25,900 & 31,057 & 10,400 \\
\hline Mar-05 & 22,190 & 558 & 64,363 & 8,000 & 35,000 & 21,387 & 33,490 & 10,442 \\
\hline Apr-05 & 21,288 & 620 & 62,398 & 5,540 & 33,800 & 24,530 & 34,908 & 9,011 \\
\hline May-05 & 21,505 & 589 & 65,212 & 6,451 & 32,500 & 24,500 & 32,243 & 10,237 \\
\hline Average & 20,159 & 245 & 63,828 & 8,070 & 33,832 & 27,068 & 23,587 & 8,931 \\
\hline Std. Dev. & 2,270 & 270 & 5,407 & 1,444 & 1,286 & 3,440 & 11,322 & 2,787 \\
\hline Minimum & 16,048 & 2 & 49,021 & 5,540 & 32,032 & 21,387 & 4,344 & 795 \\
\hline Maximum & 26,442 & 921 & 71,252 & 9,869 & 35,600 & 33,000 & 34,908 & 10,509 \\
\hline
\end{tabular}

Table 7 shows discharge volume figures provided by individual companies as part of their registration on the OOC hypoxia registry website during the winter of 2004-2005. It is not possible to tell how the companies derived this number. It could have been a long-term average, the average of the most recent quarter, a long-term maximum, or some other value. Most likely, different companies employed different approaches. In mid-July 2005, each operator was asked to review the previously submitted data and make sure the volume was representative of an annual average expressed as bbl/day. Updated or confirmed data were received from some but not all of the companies. In order to meet the report submittal deadline, the report was completed using the best available estimates of discharge volumes. Industry will continue to refine the discharge volumes and will provide revisions, as necessary, to EPA. 
Table 7 - Discharge Volume Estimate for Sampled Platforms

\begin{tabular}{|l|c|}
\hline Platform & $\begin{array}{c}\text { Discharge Volume Reported on OOC Hypoxia Registry Website } \\
\text { or Updated in July 2005 (bbl/day) }\end{array}$ \\
\hline EC 46B & 4,200 \\
\hline EC 47JP & 610 \\
\hline EC 49B & 63 \\
\hline EI 107A & 1,600 \\
\hline EI 128A-JC & 2,050 \\
\hline EI 172A & 67 \\
\hline EI 175B & 1,445 \\
\hline EI 184A & 5,591 \\
\hline EI 50-1 & 267 \\
\hline EI 57A & 2,250 \\
\hline EI 74A & 190 \\
\hline EI 95F & 1,410 \\
\hline GI 19\#3 & 63,828 \\
\hline HI 37A & 50 \\
\hline HI 39A & 100 \\
\hline HI 46A & 67 \\
\hline SM 238-190 & 690 \\
\hline SM 23G & 700 \\
\hline SM 268A & 10,500 \\
\hline SM 33D & 720 \\
\hline SM 40 JA & 8 \\
\hline SS 108D & 9,600 \\
\hline SS 157A & 1,040 \\
\hline SS 169C & 3,037 \\
\hline SS 182C & 4,643 \\
\hline SS 182E & 6,280 \\
\hline SS 189A & 1,047 \\
\hline SS 191 B & 1,700 \\
\hline SS 58A & 1,927 \\
\hline ST 148E & 1,311 \\
\hline ST 161A & 68 \\
\hline ST 164C & 1,355 \\
\hline ST 34A & 4,497 \\
\hline VR 164A & 245 \\
\hline VR 22B & 150 \\
\hline VR119D & 7,436 \\
\hline WC 102G & 1,407 \\
\hline WC 110A & 213 \\
\hline WC 130A & 401 \\
\hline WC 168A & 35 \\
\hline & \\
\hline & \\
\hline
\end{tabular}




\begin{tabular}{|l|c|}
\hline Platform & $\begin{array}{c}\text { Discharge Volume Reported on OOC Hypoxia Registry Website } \\
\text { or Updated in July 2005 (bbl/day) }\end{array}$ \\
\hline WC 170A & 1,300 \\
\hline WC 173K & 40 \\
\hline WC 215A & 1,290 \\
\hline WC 237A & 3 \\
\hline WC 53A & 292 \\
\hline WC 65JA & 1,509 \\
\hline WC 71D & 135 \\
\hline WD 45A & 2,984 \\
\hline WD 73A & 20,159 \\
\hline WD 89A & 5,000 \\
\hline Total & 175,510 \\
\hline
\end{tabular}

An accurate estimate of the discharge volume is important for the hypoxic zone study because the primary impact of oxygen-demanding materials is the total mass loading to a water body rather than the specific concentration. Mass loading is determined by multiplying concentration, flow, and a conversion factor to make the units match. For example, assume $300 \mathrm{bbl} / \mathrm{day}$ flow and a concentration of BOD of $500 \mathrm{mg} / \mathrm{L}$. The loading is:

$500 \mathrm{mg} / \mathrm{L} \times 159 \mathrm{~L} / \mathrm{bbl} \times 300 \mathrm{bbl} /$ day $\times 1 \mathrm{lb} / 454,000 \mathrm{mg}=52.5 \mathrm{lb} /$ day of BOD

Flow is directly proportional to mass loading - if the flow estimate is too high by 30 percent, the mass loading will be overestimated by 30 percent. Modelers face a challenge to select the most appropriate volume estimates when estimating the impacts of produced water discharges to the hypoxic zone.

\section{Type of Hydrocarbon Produced}

Produced water volume and parameter concentrations may have some relationship to the type of hydrocarbon produced from the wells that contribute produced water to a discharge. The operators gave a general hydrocarbon status (mostly oil, mostly gas, or both oil and gas) for each platform. This is a qualitative estimate without any specific percentage cutoffs. The hydrocarbon status is shown in Table 8 . Only 6 platforms reported primarily oil production and 20 reported primarily gas production. The remaining 24 platforms reported both types of hydrocarbon. 
Table 8 - Type of Hydrocarbon Produced at Sampled Platforms

\begin{tabular}{|c|c|c|c|}
\hline Platform & $\begin{array}{c}\text { Primary Type of } \\
\text { Hydrocarbon }\end{array}$ & Platform & $\begin{array}{c}\text { Primary Type of } \\
\text { Hydrocarbon }\end{array}$ \\
\hline EC 46B & Both & El 50-1 & Gas \\
\hline EC 47JP & Both & El 74A & Gas \\
\hline El 107A & Both & HI 37A & Gas \\
\hline El 128A-JC & Both & HI 39A & Gas \\
\hline El 172A & Both & $\mathrm{HI} 46 \mathrm{~A}$ & Gas \\
\hline El 175B & Both & SM 238-190 & Gas \\
\hline EI 57A & Both & SM 23G & Gas \\
\hline El 95F & Both & SM 268A & Gas \\
\hline SM 33D & Both & ST 148E & Gas \\
\hline SS 108D & Both & ST 161A & Gas \\
\hline SS 157A & Both & ST 164C & Gas \\
\hline SS 169C & Both & VR 22B & Gas \\
\hline SS 182C & Both & WC 102G & Gas \\
\hline SS 182E & Both & WC 110A & Gas \\
\hline SS 189A & Both & WC 130A & Gas \\
\hline SS 58A & Both & WC 173K & Gas \\
\hline ST 34A & Both & WC 215A & Gas \\
\hline VR 164A & Both & WC 53A & Gas \\
\hline VR119D & Both & WC 71D & Gas \\
\hline WC 168A & Both & El 184A & Oil \\
\hline WC 170A & Both & GI 19\#3 & Oil \\
\hline WC 237A & Both & SM $40 \mathrm{JA}$ & Oil \\
\hline WD 73A & Both & SS $191 \mathrm{~B}$ & Oil \\
\hline WD 89A & Both & WC 65JA & Oil \\
\hline EC 49B & Gas & WD 45A & Oil \\
\hline
\end{tabular}




\section{Chapter 4 - Sampling Results}

This chapter provides a summary of the analytical results from sampling the 50 platforms that are part of the study. A complete set of results is found in Appendix D. Various excerpts and analyses of the full data set are presented here.

\section{$\underline{\text { Statistical Summary of Data }}$}

Table 9 shows some basic statistics for all of the measured parameters. The mean and median give an estimate of the "average" of the data set, and the maximum and minimum show the extremes. The standard deviation (SD) shows the variability in the data set. The mean $+3 \mathrm{SD}$ statistic gives a value slightly higher than the 99th percentile of the data set. The count is the number of data points considered for the particular parameter. The dissolved and particulate BOD and TOC were run on 8 or 9 (about 10 percent) of the samples. To avoid over-weighting the platforms that were sampled three times, the average of the three values ${ }^{1}$ was used to represent the platform when calculating statistics.

\section{Table 9 - Statistical Summary of Data}

\begin{tabular}{|l|c|c|c|c|c|c|c|}
\hline & Mean & Median & Maximum & Minimum & $\begin{array}{c}\text { Standard } \\
\text { Deviation }\end{array}$ & $\begin{array}{c}\text { Mean + } \\
\text { 3StDev }\end{array}$ & $\begin{array}{c}\text { No. of } \\
\text { Platforms }\end{array}$ \\
\hline BOD, mg/L & 957 & 583 & 11,108 & 80 & 1,656 & 5,924 & 50 \\
\hline Dissolved BOD, mg/L & 498 & 432 & 1,128 & 132 & 297 & 1,389 & 9 \\
\hline Suspended BOD, mg/L & 76 & 57 & 146 & 16 & 45 & 213 & 9 \\
\hline TOC, mg/L & 564 & 261 & 4,880 & 26 & 987 & 3,524 & 50 \\
\hline Dissolved TOC, mg/L & 216 & 147 & 620 & 67 & 184 & 769 & 8 \\
\hline Suspended TOC, mg/L & 32 & 13 & 127 & 5 & 41 & 156 & 8 \\
\hline Nitrate, mg/L & 2.15 & 1.15 & 15.80 & 0.60 & 3.04 & 11.26 & 50 \\
\hline Nitrite, mg/L & 0.05 & 0.05 & 0.06 & 0.05 & 0.00 & 0.05 & 50 \\
\hline Ammonia, mg/L & 74 & 74 & 246 & 14 & 49 & 221 & 50 \\
\hline TKN, mg/L & 83 & 81 & 216 & 17 & 49 & 232 & 50 \\
\hline Orthophosphate, mg/L & 0.43 & 0.14 & 6.60 & 0.10 & 1.05 & 3.56 & 50 \\
\hline Total phosphorus, mg/L & 0.71 & 0.28 & 7.90 & 0.10 & 1.35 & 4.77 & 50 \\
\hline Conductivity, $\mu \mathrm{mhos} / \mathrm{cm}$ & 87,452 & 86,480 & 165,000 & 360 & 44,706 & 221,572 & 50 \\
\hline Salinity, ppt & 100 & 84 & 251 & 0 & 68 & 304 & 50 \\
\hline Temperature, ${ }^{\circ} \mathrm{C}$ a & 38 & 32 & 80 & 20 & 14 & 79 & 50 \\
\hline pH, SU & 6.29 & 6.50 & 7.25 & 1.77 & $0.88^{\mathrm{b}}$ & $8.94^{\mathrm{b}}$ & 50 \\
\hline
\end{tabular}

${ }^{a}$ The temperatures were measured in the field by personnel on the platforms. Although temperature should have been reported as ${ }^{\circ} \mathrm{C}$, it is likely that some of the values were actually ${ }^{\circ} \mathrm{F}$. Therefore, the statistics may not be representative.

${ }^{\mathrm{b}} \mathrm{pH}$ is measured on a logarithmic scale, so mean and SD values may not be representative.

${ }^{1}$ One of the three-time sampled platforms stopped producing water after the second sample, so only two data values are averaged to represent this platform. Another platform exhibited so much variability after three samples that the project protocol called for additional samples. 


\section{Temporal Variability}

The results of the sampling of the 16 platforms that were sampled on more than one date show that concentrations do vary. The procedure approved by EPA for this project for determining acceptable variability among samples at the same platform looks only at BOD results. The procedure uses an acceptability criterion of $\mathrm{CV}<0.6$. Fifteen of the sixteen platforms have $\mathrm{CVs}$ ranging from 0.10 to 0.46 ; these all demonstrate acceptable temporal variability. The sixteenth platform had a CV of 0.69 after three samples. Following a fourth sample, the CV increased to 0.94. At this point, the company was instructed to collect a fifth and sixth sample. Those results mirrored the earlier results in their inconsistency - one was high and the other much lower. The $\mathrm{CV}$ for all six samples is 1.08. Apparently this platform has a variable BOD concentration in its produced water discharge.

Although no CVs were calculated for parameters other than BOD, those parameters showed varying degree of temporal variability, too. Some platforms showed a great deal of consistency among the three samples. Others had two of the three samples at similar levels and the third sample at a somewhat different level.

The graphs presented in this chapter do not display the individual data points for each sample at the platforms sampled more than once. To avoid overweighting them, each platform is presented as an average of all samples collected at that location. This allows easy comparison of the spatial (or platform-to-platform) variability. To examine the temporal variability, readers must look at the individual sample results in Appendix D.

\section{Consideration of Outliers}

Outliers are data points that are substantially higher or lower than the rest of the data in a set. In data sets with high outlier values, the mean may be distorted by the outliers, and the median may be a better estimate of the "representative" value. In this data set, the mean and median were examined for each parameter. Where the two values are very different, the raw data were checked to see if the discrepancy was caused by one or a few outliers. Among the target parameters for this study (the oxygen-demanding substances), those that showed more than minimal discrepancy between mean and median (mean at least 1.5 times as high as median) are BOD, TOC, nitrate, orthophosphate, and total phosphorus. Each of these is discussed below.

BOD: Figure 5 shows the BOD values from all platforms in bar chart format, listed alphabetically by lease. Each bar represents a different platform; where more than one sample was collected at a platform, the bar represents the average of the samples. Two values clearly stand out from the rest of the data here. The highest value is $11,108 \mathrm{mg} / \mathrm{L}$ and the second highest is $5,378 \mathrm{mg} / \mathrm{L}$. The remaining values are all less than $2,000 \mathrm{mg} / \mathrm{L}$.

Table 10 shows the effect on BOD statistics if first one and then both of these outliers are removed from the data set. As the outliers are removed from the data set, the mean decreases by 32 percent and the mean and median become more similar. The SD decreases by 76 percent. 
Figure 5 - Plot of BOD Results from All Platforms (values shown in mg/L)

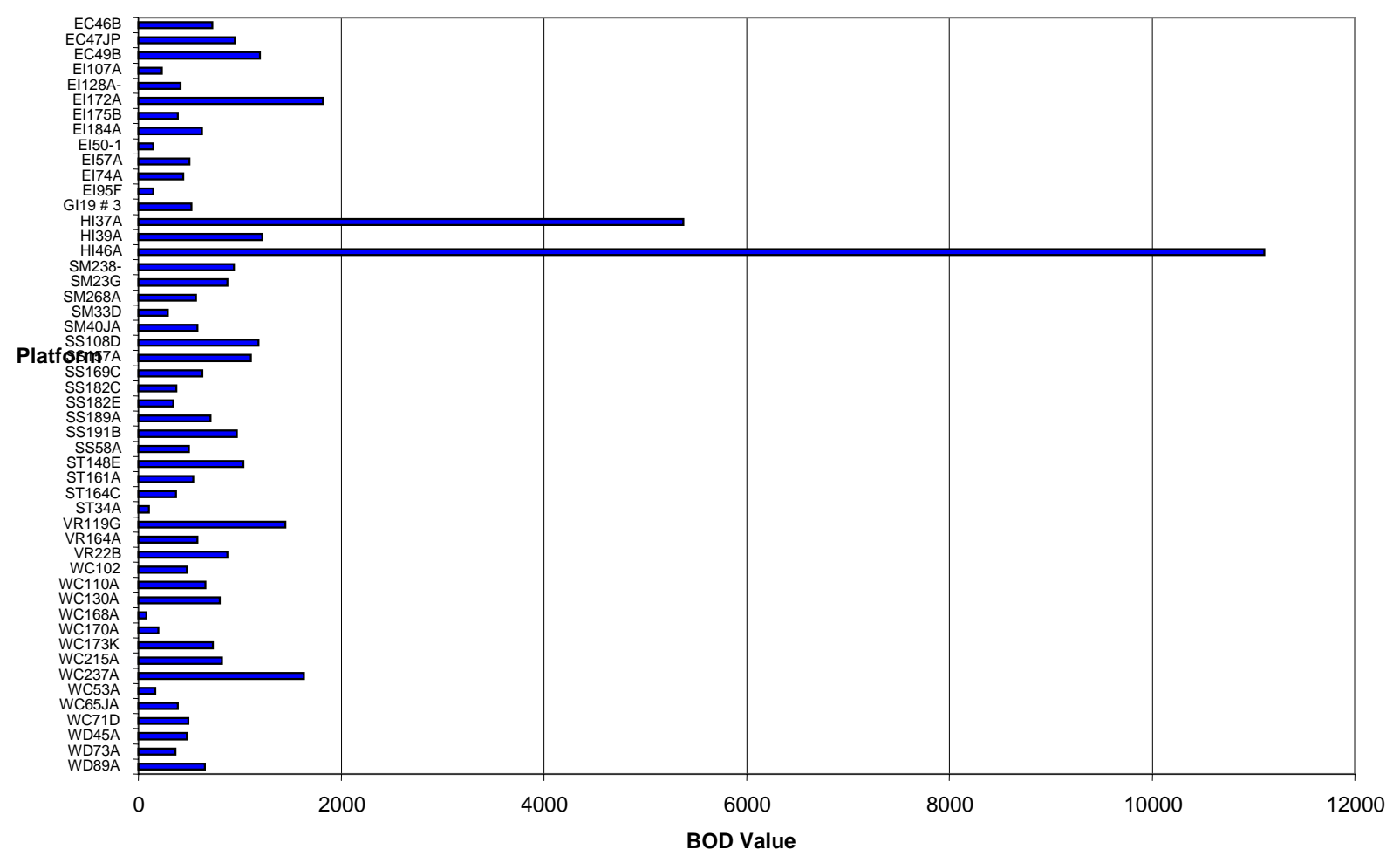


Table 10 - Change in Statistical Properties after Removing BOD Outliers

\begin{tabular}{|l|c|c|c|c|c|c|c|}
\hline Parameter & Mean & Median & Maximum & Minimum & SD & $\begin{array}{c}\text { Mean + 3 } \\
\text { SD }\end{array}$ & $\begin{array}{c}\text { No. of } \\
\text { Platforms }\end{array}$ \\
\hline All BOD data, mg/L & 957 & 583 & 11,108 & 80 & 1,656 & 5,924 & 50 \\
\hline $\begin{array}{l}\text { All BOD data except } \\
\text { highest outlier, mg/L }\end{array}$ & 750 & 582 & 5,378 & 80 & 780 & 3,089 & 49 \\
\hline $\begin{array}{l}\text { All BOD data except } \\
\text { two highest outliers, } \\
\text { mg/L }\end{array}$ & 654 & 576 & 1,821 & 80 & 394 & 1,837 & 48 \\
\hline
\end{tabular}

Outliers should not automatically be dropped from data sets without a clear understanding of why they differ from the rest of the data set. In this instance, the two BOD outlier data points were measured at platforms in the HI (High Island) lease area, which is the westernmost lease area included in the study.

Figure 6 shows a plot of average BOD by lease area, with lease areas portrayed in sequence from west to east. The average BOD for $\mathrm{HI}$ is nearly $6,000 \mathrm{mg} / \mathrm{L}$. No other extremely high values were reported in any different lease area, and none of the other average BOD values exceeds $1,000 \mathrm{mg} / \mathrm{L}$. All of the HI platforms sampled in this program, as well as all other HI platforms listed on the OOC hypoxia registry website, are primarily gas producers. The lighter hydrocarbons in gas may be more soluble and more readily detectable under the BOD test.

Figure 6 - BOD Values by Lease Area (values shown in mg/L)

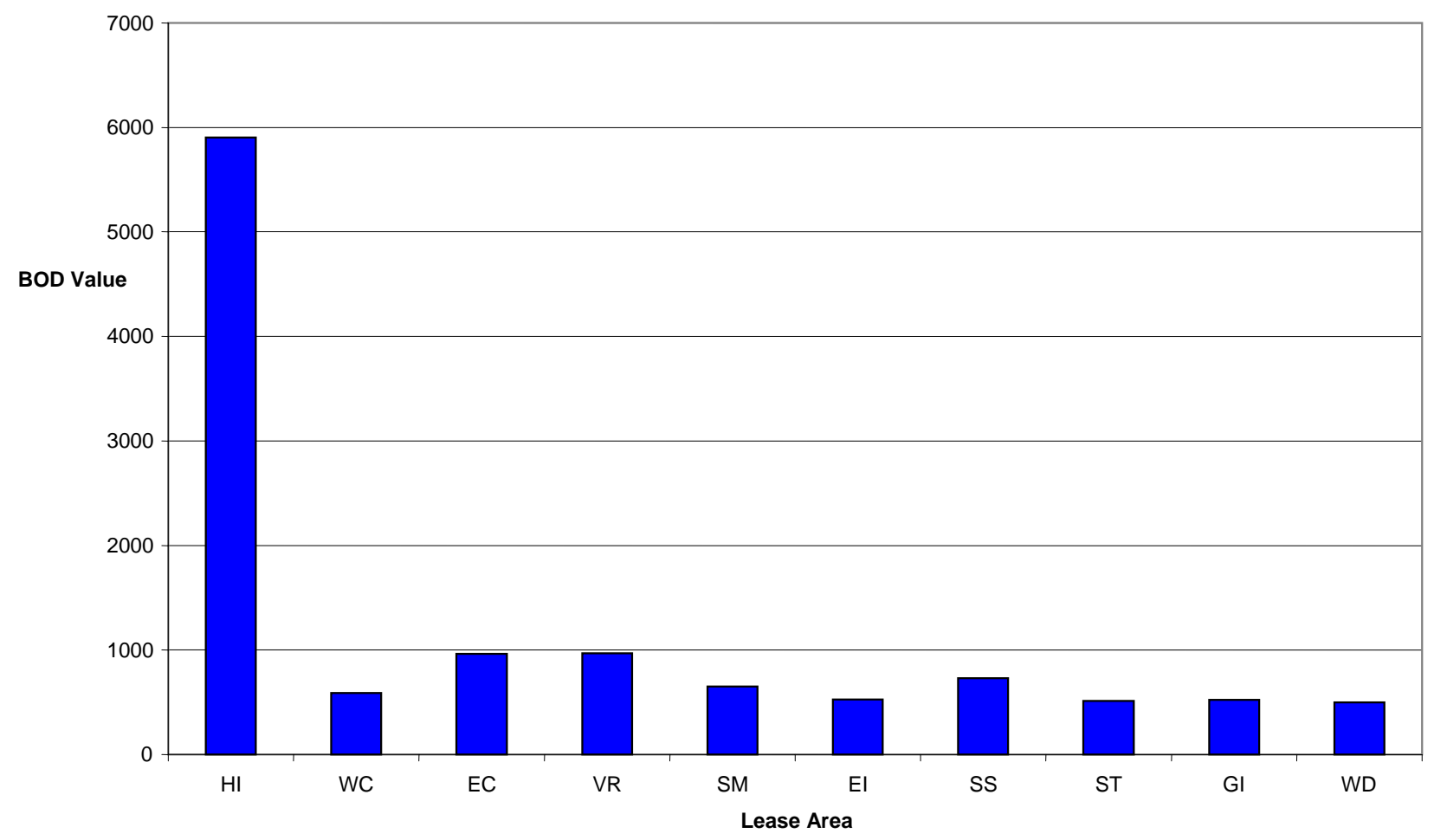


The OOC hypoxia registry website contains 287 platforms located throughout the hypoxic zone. Only 10 of the 296 registered platforms (about 3 percent) are located in the High Island lease area. There is no reason to believe the two outliers are erroneous data points (i.e., incorrectly collected sample, bad lab analysis). Nevertheless, they are not typical of most of the area within the hypoxic zone and should probably be treated separately when water quality models are run.

TOC: Figure 7 shows the TOC values from all platforms in bar chart format. Four values clearly stand out from the rest of the data here. Two of the values exceed 4,000 $\mathrm{mg} / \mathrm{L}$ and the other two exceed $2,000 \mathrm{mg} / \mathrm{L}$. The remaining values are all less than $1,000 \mathrm{mg} / \mathrm{L}$. The two platforms that had high BOD are part of this group of four high-TOC platforms. They are the second and third highest TOC values $(4,700 \mathrm{mg} / \mathrm{L}$ and $2,440 \mathrm{mg} / \mathrm{L})$. The highest $(4,880 \mathrm{mg} / \mathrm{L})$ and fourth highest $(2,990 \mathrm{mg} / \mathrm{L})$ TOC values are found at platforms that were not outliers for BOD.

Figure 7 - Plot of TOC Results from All Platforms (values shown in mg/L)

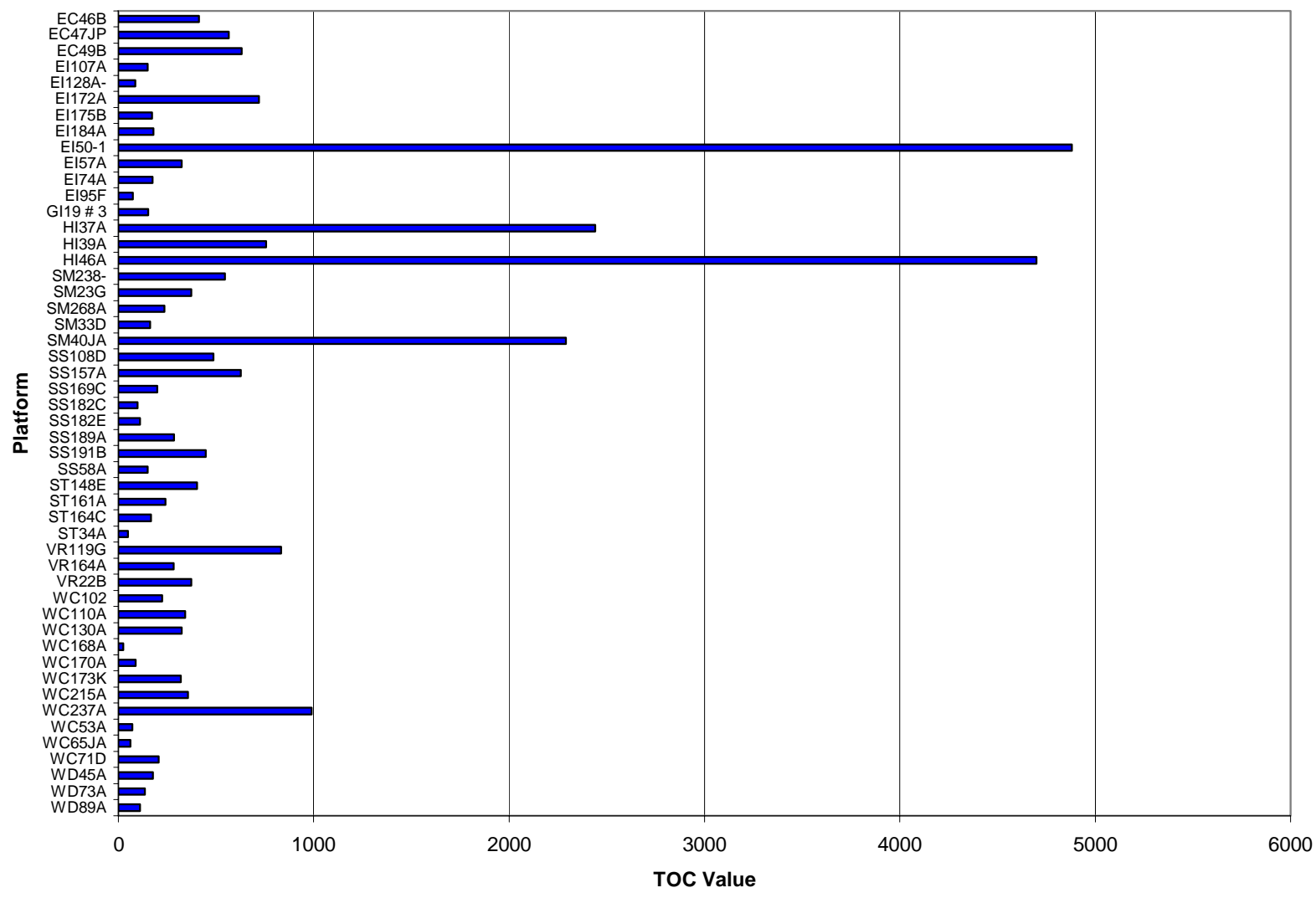


Table 11 shows the effect on TOC statistics if the two highest and then the four highest outliers are removed from the data set. As the outliers are removed from the data set, the mean decreases by 46 percent, and the mean and median become more similar. The SD decreases by 77 percent.

Table 11 - Change in Statistical Properties after Removing TOC Outliers

\begin{tabular}{|l|c|c|c|c|c|c|c|}
\hline Parameter & Mean & Median & Maximum & Minimum & SD & $\begin{array}{c}\text { Mean + 3 } \\
\text { SD }\end{array}$ & $\begin{array}{c}\text { No. of } \\
\text { Platforms }\end{array}$ \\
\hline All TOC data, mg/L & 563 & 238 & 4,880 & 26 & 987 & 3,524 & 50 \\
\hline $\begin{array}{l}\text { All TOC data except } \\
\text { two highest outliers, } \\
\text { mg/L }\end{array}$ & 388 & 238 & 2,440 & 26 & 472 & 1,805 & 48 \\
\hline $\begin{array}{l}\text { All BOD data except } \\
\text { four highest outliers, } \\
\text { mg/L }\end{array}$ & 302 & 230 & 990 & 26 & 227 & 982 & 46 \\
\hline
\end{tabular}

Figure 8 shows a plot of average TOC by lease area, with lease areas portrayed in sequence from west to east. High Island area shows a high concentration of TOC, but there is more variation in the other blocks than was seen for BOD in Figure 6. TOC concentration appears to decrease to the eastern edge of the hypoxic zone.

Figure 8 - TOC Values by Lease Area (values shown in mg/L)

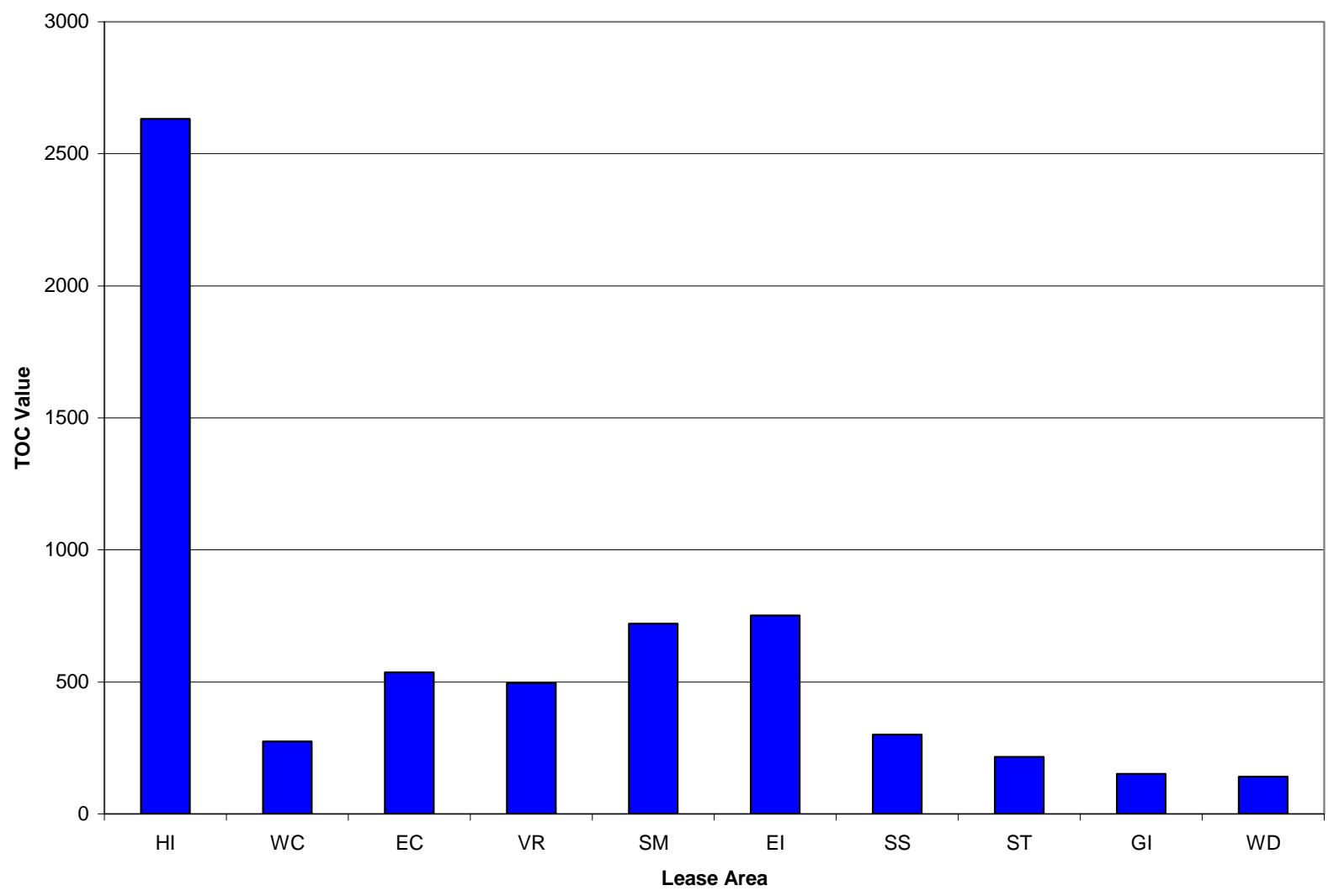


Nitrate: Figure 9 shows the nitrate values from all platforms in bar chart format. Three values clearly stand out from the rest of the data here. They are $15.8 \mathrm{mg} / \mathrm{L}, 12.5 \mathrm{mg} / \mathrm{L}$, and $11.2 \mathrm{mg} / \mathrm{L}$. The remaining values all are less than $5 \mathrm{mg} / \mathrm{l}$.

Figure 9 - Plot of Nitrate Results from All Platforms (values shown in mg/L)

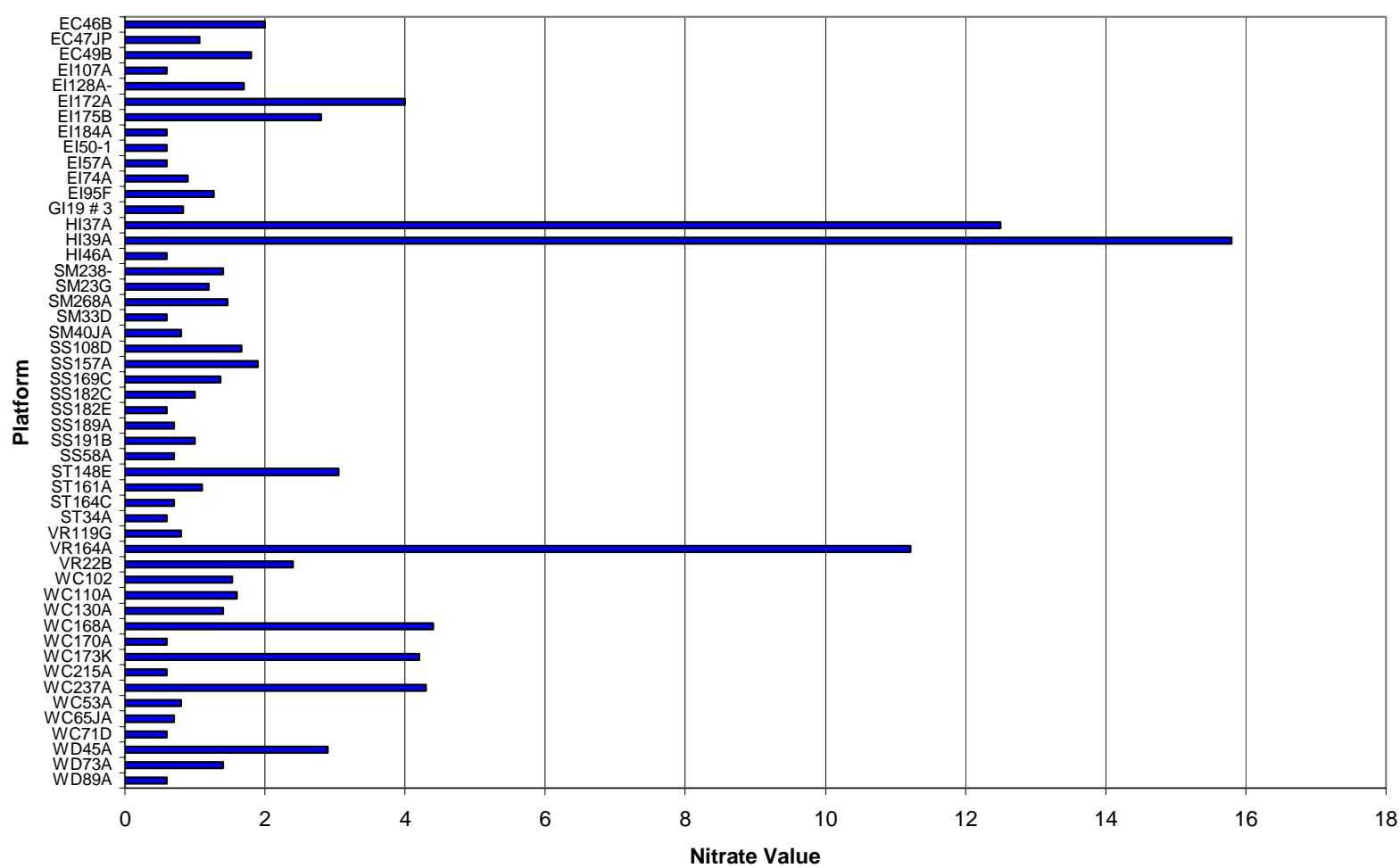

Although not shown in Figure 9 because only platform averages are reported for those platforms sampled more than once, the highest individual result was at VR 164A, the platform sampled six times. That value was $57.5 \mathrm{mg} / \mathrm{L}$. The other five results from that platform were much lower $(0.6 \mathrm{mg} / \mathrm{L}, 0.6 \mathrm{mg} / \mathrm{L}, 0.7 \mathrm{mg} / \mathrm{L}, 0.9 \mathrm{mg} / 1$, and $7.0 \mathrm{mg} / \mathrm{L})$. The average for the platform is still high enough to be one of the outlier values.

Table 12 shows the effect on nitrate statistics if these three outliers are removed from the data set. As the outliers are removed from the data set, the mean decreases by 36 percent and the mean and median become more similar. The SD decreases by 63 percent.

Table 12 - Change in Statistical Properties after Removing Nitrate Outliers

\begin{tabular}{|l|c|c|c|c|c|c|c|}
\hline Parameter & Mean & Median & Maximum & Minimum & SD & $\begin{array}{c}\text { Mean + 3 } \\
\text { SD }\end{array}$ & $\begin{array}{c}\text { No. of } \\
\text { Platforms }\end{array}$ \\
\hline $\mathrm{All} \mathrm{NO}_{3}$ data, $\mathrm{mg} / \mathrm{L}$ & 2.2 & 1.2 & 15.8 & 0.6 & 3.0 & 11.3 & 50 \\
\hline $\begin{array}{l}\text { All } \mathrm{NO}_{3} \text { data except three } \\
\text { highest outliers, } \mathrm{mg} / \mathrm{L}\end{array}$ & 1.4 & 1.1 & 4.4 & 0.6 & 1.1 & 4.7 & 50 \\
\hline
\end{tabular}


Figure 10 shows a plot of average nitrate by lease area, with lease areas portrayed in sequence from west to east. The High Island area shows a high concentration of nitrate, with a secondary peak showing for Vermillion. The other lease areas have relatively consistent levels of nitrate.

Figure 10 - Nitrate Values by Lease Area (values shown in mg/L)

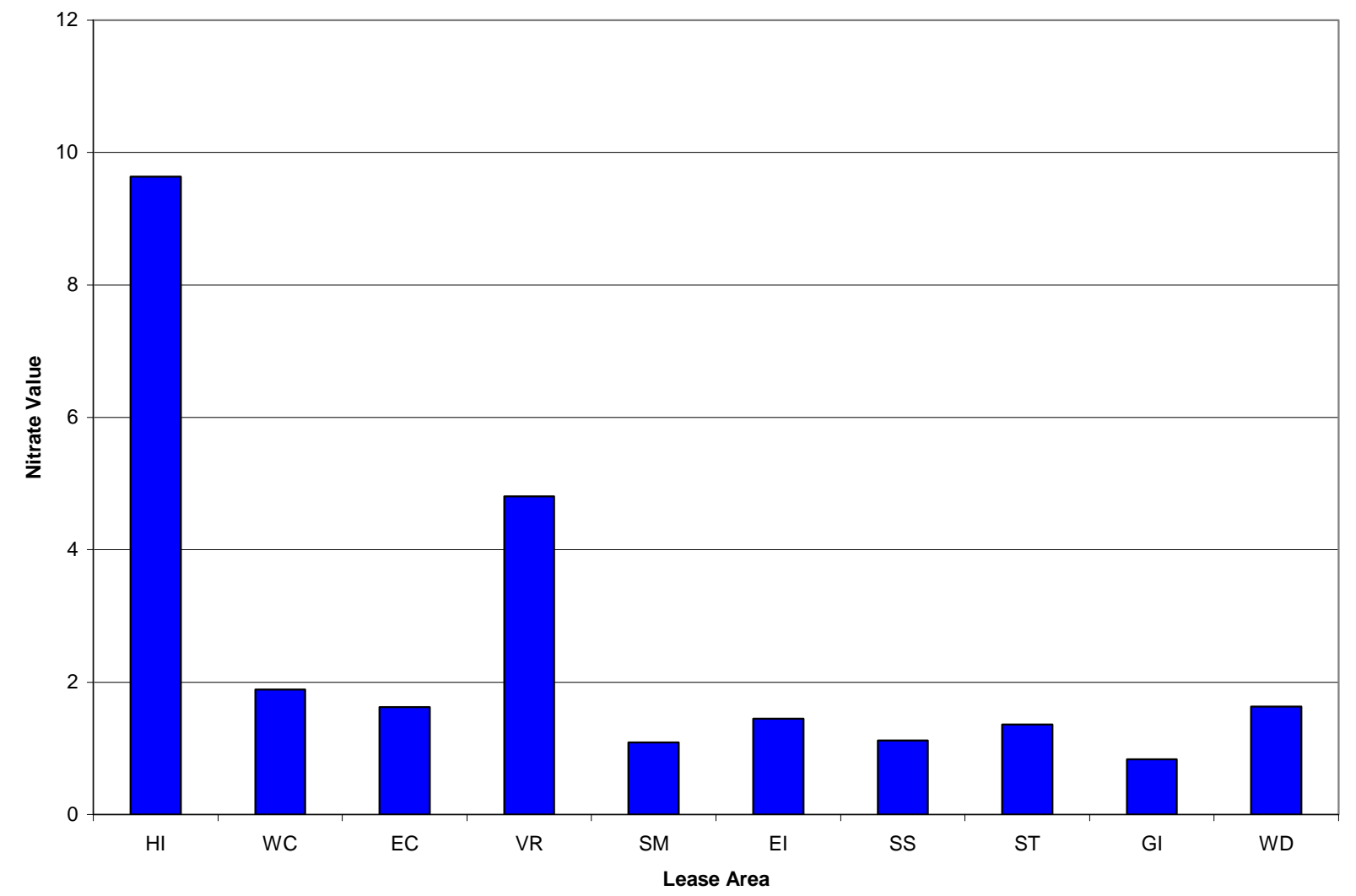

Orthophosphate: Figure 11 shows the orthophosphate values from all platforms in bar chart format. Three values clearly stand out from the rest of the data here. The highest value is $6.6 \mathrm{mg} / \mathrm{L}$, and the second and third highest are both about $2.8 \mathrm{mg} / \mathrm{L}$. The remaining values all are less than $1.1 \mathrm{mg} / \mathrm{L}$. All results from individual platforms are averaged, and then all platforms in a lease area are averaged again. This potentially can disguise the impact of a single high sample result. 
Figure 11 - Plot of Orthophosphate Results from All Platforms (values shown in mg/L)

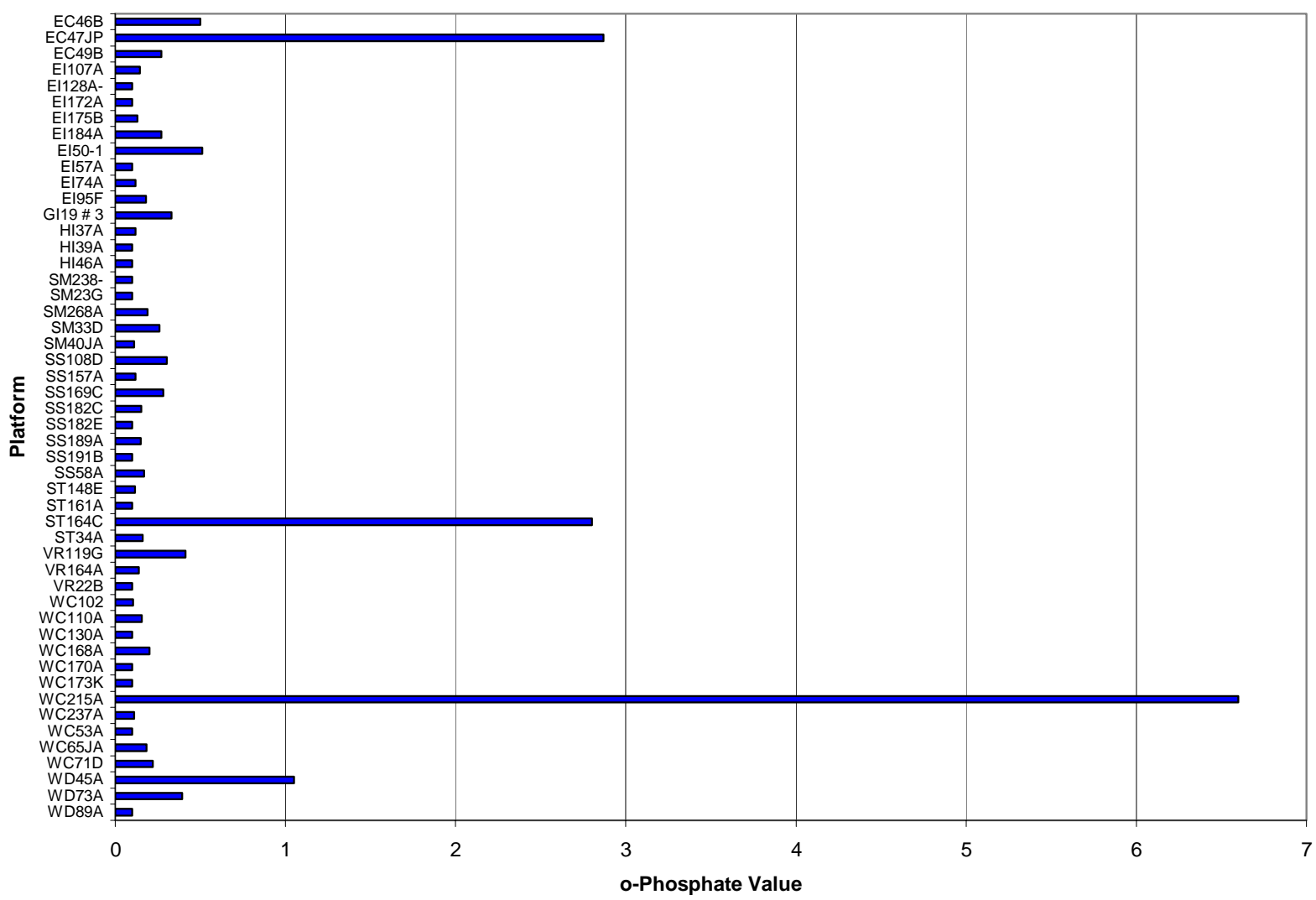

Although not shown in Figure 11 because only platform averages are reported for those platforms sampled more than once, the highest individual result was at a three-time sampled platform. That value was $8.1 \mathrm{mg} / \mathrm{L}$. The other two results from that platform were much lower $(0.16 \mathrm{mg} / \mathrm{L}$ and $0.35 \mathrm{mg} / \mathrm{L})$. The average for the platform is still high enough to be one of the outlier values.

Table 13 shows the effect on orthophosphate statistics if the highest and then the three highest outliers are removed from the data set. As the outliers are removed from the data set, the mean decreases by 56 percent and the mean and median become more similar. The SD decreases by 84 percent.

Table 13 - Change in Statistical Properties after Removing Orthophosphate Outliers

\begin{tabular}{|l|c|c|c|c|c|c|c|}
\hline Parameter & Mean & Median & Maximum & Minimum & SD & $\begin{array}{c}\text { Mean + 3 } \\
\text { SD }\end{array}$ & $\begin{array}{c}\text { No. of } \\
\text { Platforms }\end{array}$ \\
\hline All ortho-P data, mg/L & 0.4 & 0.1 & 6.6 & 0.1 & 1.1 & 3.6 & 50 \\
\hline $\begin{array}{l}\text { All ortho-P data except } \\
\text { highest outlier, mg/L }\end{array}$ & 0.3 & 0.1 & 2.9 & 0.1 & 0.6 & 2.0 & 49 \\
\hline $\begin{array}{l}\text { All ortho-P data except } \\
\text { three highest outliers, } \\
\text { mg/L }\end{array}$ & 0.2 & 0.1 & 1.1 & 0.1 & 0.2 & 0.7 & 47 \\
\hline
\end{tabular}


Figure 12 shows a plot of average orthophosphate by lease area, with lease areas portrayed in sequence from west to east. Unlike the previous geographic plots, the High Island area does not have a substantially higher average concentration. There is much more variation in the other blocks, with peaks in East Cameron, South Timbalier, West Cameron, and West Delta. All results from individual platforms are averaged, and then all platforms in a lease area are averaged again. This potentially can disguise the impact of a single high sample result.

Figure 12 - Orthophosphate Values by Lease Area (values shown in mg/L)

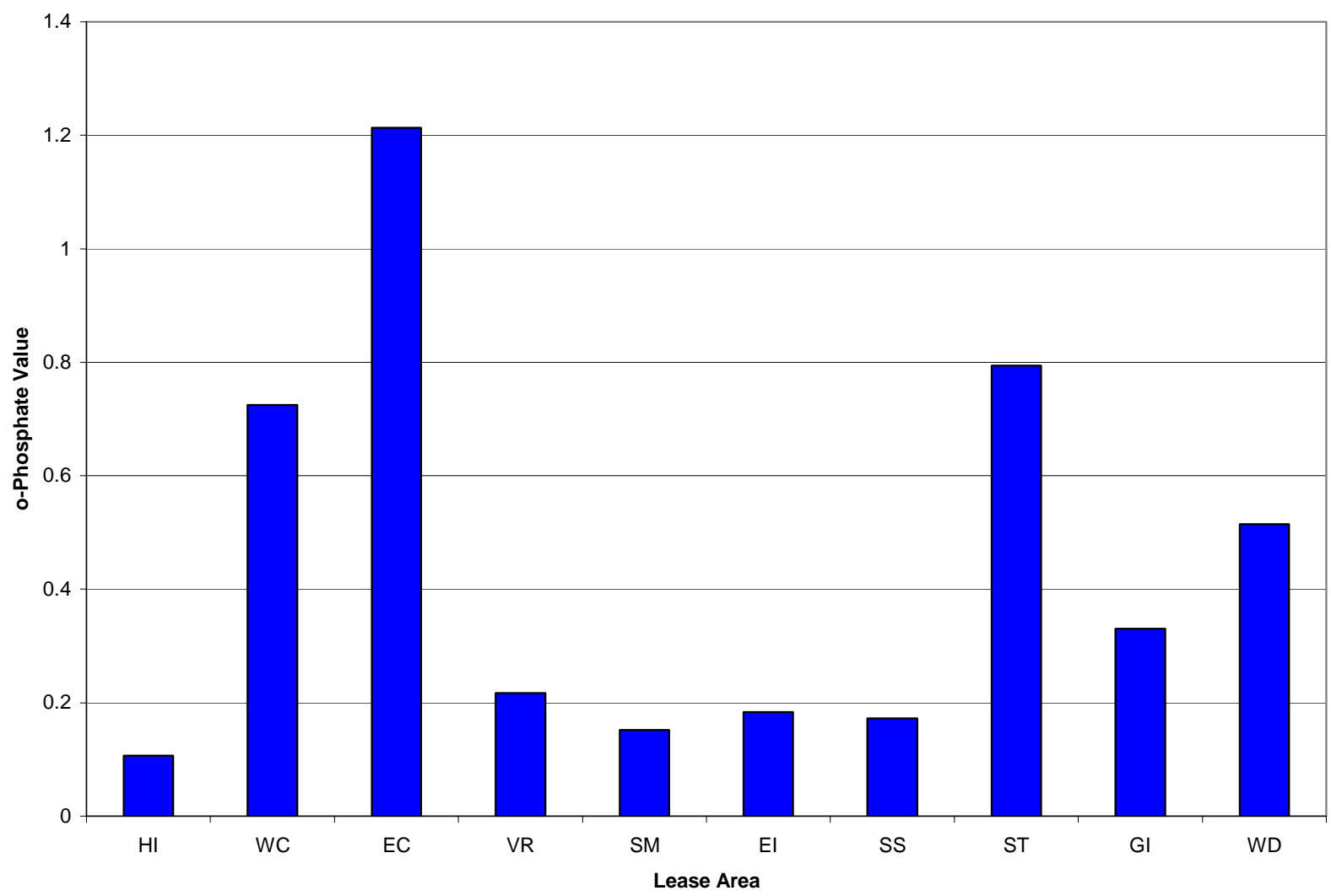

Total Phosphorus: Figure 13 shows the total phosphorus values from all platforms in bar chart format. Unlike the other parameters that were previously discussed, this distribution is more complicated. Most of the data points are less than $1.0 \mathrm{mg} / \mathrm{L}$, but six platforms have values higher than $2.0 \mathrm{mg} / \mathrm{L}$, and four platforms have values equal to or higher than $3.0 \mathrm{mg} / \mathrm{L}$. 


\section{Figure 13 - Plot of Total Phosphorus Results from All Platforms (values shown in mg/L)}

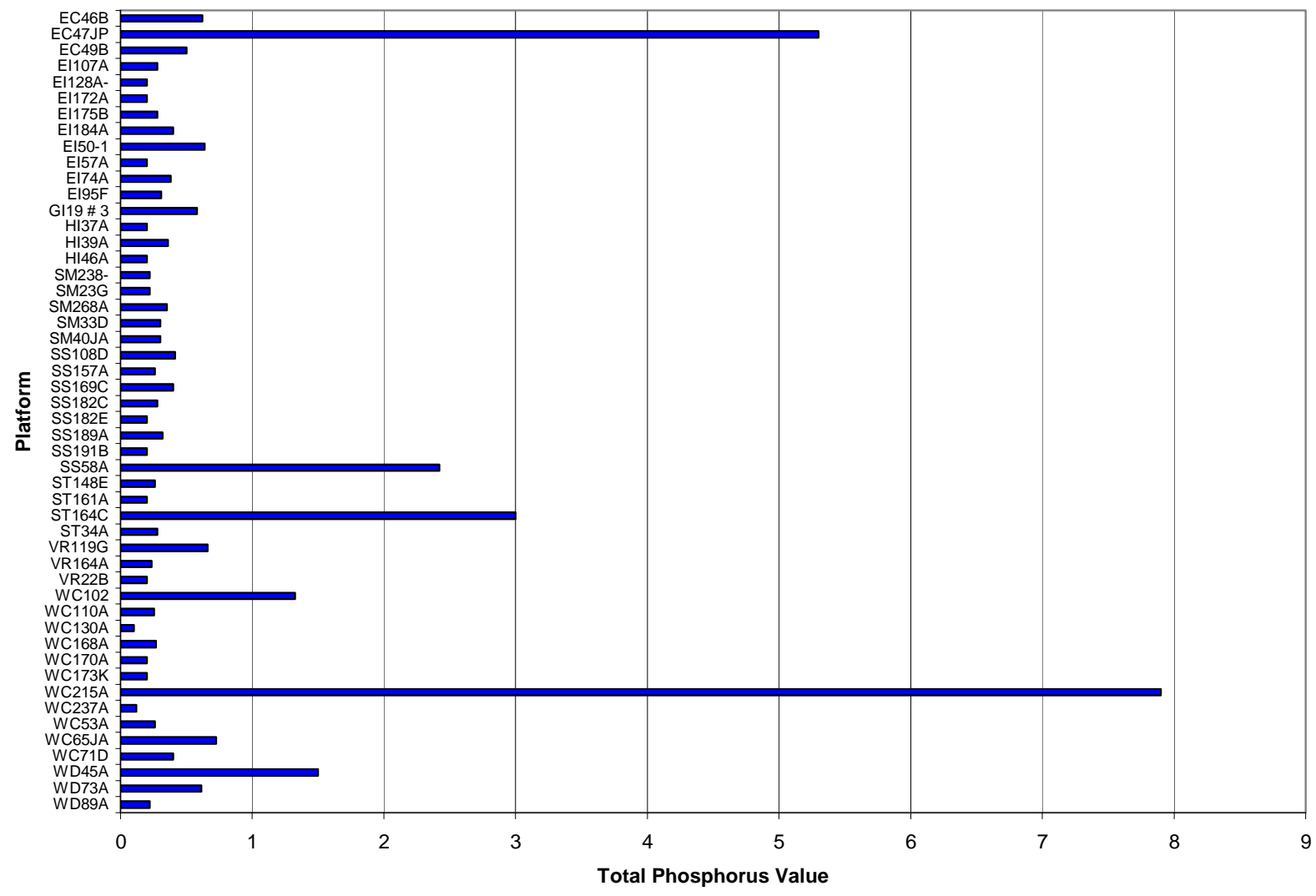

The highest value for a platform is $7.9 \mathrm{mg} / \mathrm{L}$, although one value at a platform sampled three times was measured at $10.6 \mathrm{mg} / \mathrm{L}$. However, when averaged with the other two samples, the mean at that platform is $5.3 \mathrm{mg} / \mathrm{L}$.

Table 14 shows the effect on total phosphorus statistics if the two highest and then the four highest outliers are removed from the data set. As the outliers are removed from the data set, the mean decreases by 48 percent and the mean and median become more similar. The SD decreases by 80 percent.

Table 14 - Change in Statistical Properties after Removing Total Phosphorus Outliers

\begin{tabular}{|l|c|c|c|c|c|c|c|}
\hline Parameter & Mean & Median & Maximum & Minimum & SD & $\begin{array}{c}\text { Mean + 3 } \\
\text { SD }\end{array}$ & $\begin{array}{c}\text { No. of } \\
\text { Platforms }\end{array}$ \\
\hline All total-P data, mg/L & 0.71 & 0.28 & 7.90 & 0.10 & 1.35 & 4.77 & 50 \\
\hline $\begin{array}{l}\text { All total-P data except two } \\
\text { highest outlier, } \mathrm{mg} / \mathrm{L}\end{array}$ & 0.46 & 0.28 & 3.00 & 0.10 & 0.55 & 2.10 & 48 \\
\hline $\begin{array}{l}\text { All total-P data except four } \\
\text { highest outliers, } \mathrm{mg} / \mathrm{L}\end{array}$ & 0.37 & 0.28 & 1.50 & 0.10 & 0.27 & 1.18 & 46 \\
\hline
\end{tabular}


Figure 14 shows a plot of average total phosphorus by lease area, with lease areas portrayed in sequence from west to east. East Cameron has the highest total phosphorus, followed by West Cameron, South Timbalier, and West Delta.

Figure 14 - Total Phosphorus Values by Lease Area (values shown in mg/L)

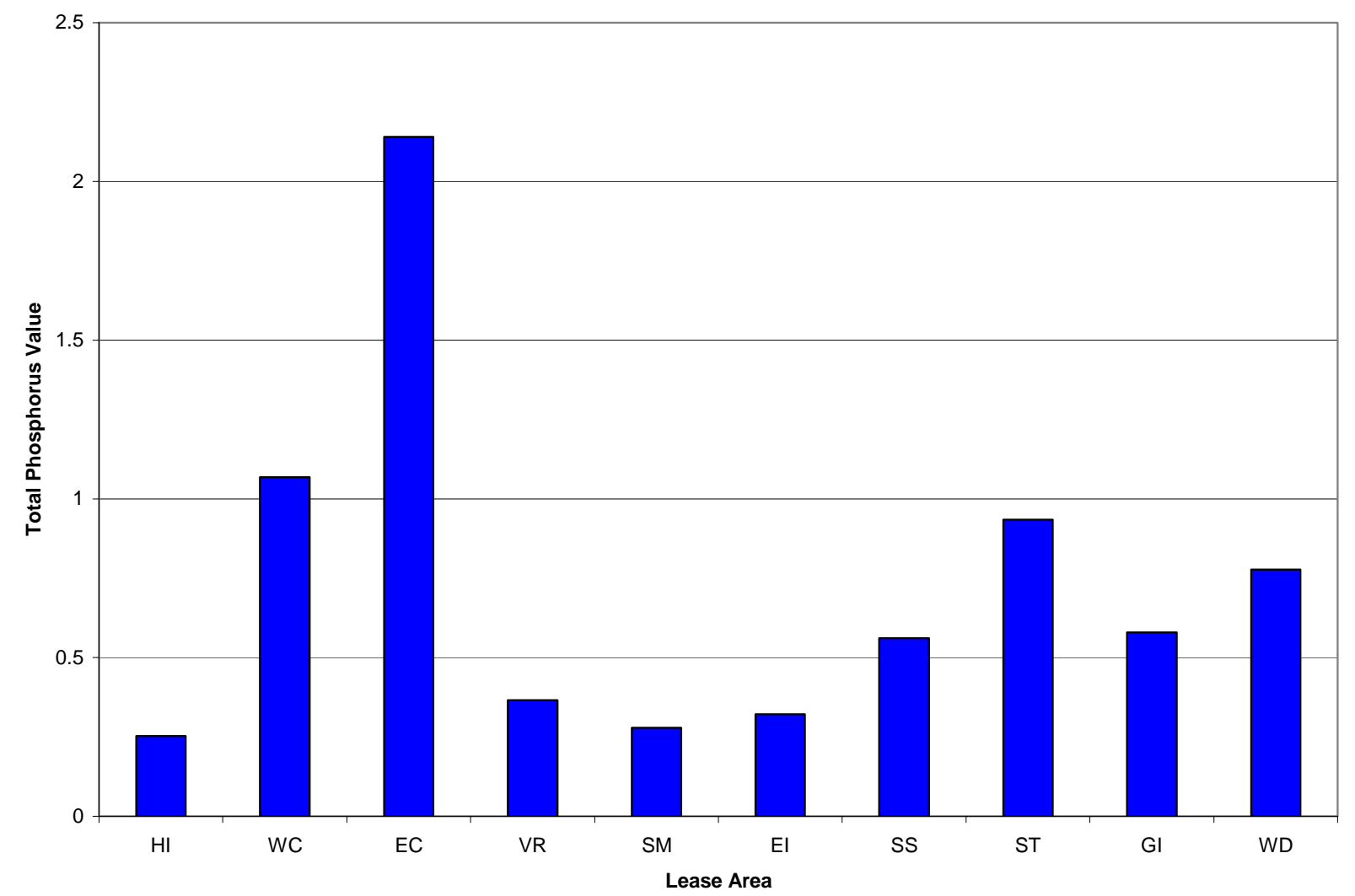

$\underline{\text { Associations between Parameters }}$

Some of the parameters sampled in this study are expected to exhibit an association with other parameters. For example, TKN is the sum of ammonia and organic nitrogen. Therefore, TKN and ammonia may be closely related unless organic nitrogen concentrations are extremely high, which is not the case for produced water. Linear regression correlations between selected pairs of parameters were calculated and are displayed in Table 15. Although many different comparisons could be made here, several examples are shown as illustrations of possible associations. A positive correlation coefficient indicates a direct association (e.g., as parameter A increases, so does parameter B). A negative correlation coefficient indicates that as parameter $\mathrm{A}$ increases, parameter B decreases. Correlation coefficients range from 0 to 1 , or from 0 to -1 for negative correlations. A correlation coefficient near to 1 or -1 indicates a strong association between the two parameters, while a correlation coefficient near 0 indicates a weak association. The number of samples is considered when evaluating the significance of the association. 
Table 15 - Linear Regression Correlations between Parameters

\begin{tabular}{|l|l|c|c|}
\hline Parameter A & Parameter B & $\begin{array}{c}\text { Correlation } \\
\text { Coefficient }\end{array}$ & No. of Samples \\
\hline BOD & Dissolved BOD & 0.98 & 9 \\
\hline TOC & Dissolved TOC & 0.96 & 50 \\
\hline BOD & TOC & 0.67 & 50 \\
\hline Ammonia & TKN & 0.97 & 50 \\
\hline Ammonia & Nitrate & -0.32 & 50 \\
\hline Ammonia & Nitrite & -0.11 & 50 \\
\hline Orthophosphate & Total phosphorous & 0.95 & 50 \\
\hline Conductivity & Salinity & 0.97 & \\
\hline
\end{tabular}

The association between BOD and dissolved BOD is very strong, as is the association between TOC and dissolved TOC. This reflects the large percentage of both BOD (97 percent) and TOC (89 percent) that are in the dissolved form. The association between BOD and TOC is not as strong as some of the other correlations.

For the nutrients, ammonia correlates very well with TKN (i.e., increases in ammonia track closely to increases in TKN). Since ammonia makes up about 95 percent of the TKN, this is not surprising. Ammonia does not correlate well with nitrate or nitrite. The correlation coefficients for both are low. The association between these parameters is a negative correlation. Orthophosphate correlates very well with total phosphorus.

The high correlation between conductivity and salinity is not surprising, because they are both measuring similar properties.

\section{$\underline{\text { Relationship between Type of Hydrocarbon Produced and Concentrations }}$}

One of the factors used to select the platforms that were tested three times is the type of hydrocarbon produced by a platform. Table 8 shows the primary hydrocarbon production for each of the 50 platforms in the study. Table 16 provides average concentrations of the oxygendemanding and nutrient parameters for the platforms in each of three production categories (mostly oil, mostly gas, and a mix of both oil and gas). As noted previously, produced water from gas production often contains a higher proportion of lighter hydrocarbons that are more soluble. This is demonstrated by comparing the average BOD and TOC concentrations from the mostly-oil and mostly-gas platforms. The mostly-gas platforms have considerably higher average BOD and TOC values. The data indicate that nitrate, orthophosphate, and total phosphorus are higher in the mostly-gas platforms, whereas ammonia and TKN are higher in the mostly-oil platforms. The average concentrations for the platforms having both types of production are not consistently above, below, or in between the mostly-oil and mostly-gas platform averages. 
Table 16 - Average Concentrations Displayed by Type of Hydrocarbon Produced from a Platform

\begin{tabular}{|c|c|c|c|}
\hline & \multicolumn{3}{|c|}{$\begin{array}{c}\text { Average Concentration (mg/L) for All Platforms in a Hydrocarbon Production } \\
\text { Category }\end{array}$} \\
\hline Parameter & $\begin{array}{c}\text { 6 Platforms Producing } \\
\text { Mostly Oil }\end{array}$ & $\begin{array}{c}\text { 20 Platforms Producing } \\
\text { Mostly Gas }\end{array}$ & $\begin{array}{c}\text { 24 Platforms } \\
\text { Producing Both Oil } \\
\text { and Gas }\end{array}$ \\
\hline BOD & 595 & 1,444 & 642 \\
\hline TOC & 551 & 888 & 297 \\
\hline Nitrate & 1.14 & 2.71 & 1.94 \\
\hline Nitrite & 0.05 & 0.05 & 0.05 \\
\hline Ammonia & 92 & 57 & 85 \\
\hline TKN & 111 & 65 & 92 \\
\hline Ortho-P & 0.34 & 0.61 & 0.30 \\
\hline Total-P & 0.62 & 0.86 & 0.61 \\
\hline
\end{tabular}




\section{Chapter 5 - Estimation of Mass Loading}

A primary goal of this study is to estimate the mass loading of each of the oxygen-demanding pollutants from the 50 platforms sampled in the study. As noted in Chapter 3, mass loading is calculated by multiplying concentrations (reported in Chapter 4 and Appendix D) by the discharge volume (reported in Chapter 3 ) and then by a conversion factor to allow units to match.

\section{$\underline{\text { Uncertainty }}$}

Neither concentration nor discharge volume is a fixed quantity, nor is there necessarily a relationship between them. Both fluctuate over time, so it is difficult to provide a single-number estimate for either factor or for the load. The analytical data for the measured parameters should be reasonably accurate and exhibit a low degree of uncertainty. The QA/QC procedures implemented for this study provide confidence in the fundamental accuracy of the data. The variability within any particular parameter differs from platform to platform and over time, as indicated by the platforms sampled more than once. The variability is not consistent between parameters, either. While the project's limitations on timing and number of samples precluded long-term sampling, a significant fraction of the total volume of produced water discharged to the hypoxic zone was evaluated. Regardless, considering the wide range of geological conditions from which the produced waters are drawn, a certain degree of variability is inevitable.

One important issue related to concentration is how values reported as "less than" (below the method detection limit, or MDL) are treated. Some of the analytical results for nitrate, nitrite, orthophosphate, and total phosphorus are reported that way by the analytical laboratory. This means that the actual concentration for those analyses falls somewhere between zero and the "less than" value reported. For example, many nitrite values are reported as $<0.05 \mathrm{mg} / \mathrm{L}$. When calculating loads, these values can be treated as equal to $0.05 \mathrm{mg} / \mathrm{L}$, as zero, or as some value in between.

Perhaps the largest source of variability and uncertainty relates to having accurate discharge volume values. Table 7 shows the data entered by operators to the OOC hypoxic zone registry during the winter of 2004-2005. More recent and accurate average data were provided in June and July of 2005 for a few platforms; the updated values were substituted into Table 7 . It is difficult to characterize the variable volume of produced water that is discharged over time (see Table 6 for examples) by a single value. Nevertheless, this is the only complete set of volume data available at this time.

\section{Estimation Methodology}

For concentration, the average value for each platform is used. Any "less than" values are treated as being equal to the value following the "less than" sign (e.g., the nitrite values mentioned earlier would be treated as equal to $0.05 \mathrm{mg} / \mathrm{L}$ ). This overestimates the true concentration for those values, and, as such, is a conservative approach. For discharge volume, the volume figures from Table 7 are used. 


\section{Loading Estimates}

Tables 17 to 20 show the discharge volume for each platform followed by concentration and loading for the oxygen-demanding parameters.

Table 17 - Loading Estimates for BOD and TOC

\begin{tabular}{|c|c|c|c|c|c|}
\hline Platform & $\begin{array}{l}\text { Discharge } \\
\text { Volume } \\
\text { (bbl/day) }\end{array}$ & $\begin{array}{c}\text { BOD } \\
\text { Concentration } \\
(\mathrm{mg} / \mathrm{L})\end{array}$ & $\begin{array}{c}\text { BOD Loading } \\
\text { (lb/day) }\end{array}$ & $\begin{array}{c}\text { TOC } \\
\text { Concentration } \\
(\mathrm{mg} / \mathrm{L})\end{array}$ & $\begin{array}{c}\text { TOC Loading } \\
\text { (lb/day) }\end{array}$ \\
\hline EC 46B & 4,200 & 732 & 1,080 & 412 & 606 \\
\hline EC 47JP & 610 & 954 & 204 & 565 & 121 \\
\hline EC 49B & 63 & 1,200 & 26 & 630 & 14 \\
\hline EI 107A & 1,600 & 234 & 131 & 150 & 84 \\
\hline EI 128A-JC & 2,050 & 415 & 298 & 86 & 62 \\
\hline EI 172A & 67 & 1,821 & 43 & 720 & 17 \\
\hline EI 175B & 1,445 & 392 & 198 & 172 & 87 \\
\hline EI 184A & 5,591 & 628 & 1,230 & 178 & 349 \\
\hline EI 50-1 & 267 & 147 & 14 & 4,880 & 456 \\
\hline EI 57A & 2,250 & 503 & 396 & 325 & 256 \\
\hline EI 74A & 190 & 442 & 29 & 174 & 12 \\
\hline EI 95F & 1,410 & 148 & 73 & 74 & 37 \\
\hline GI 19\#3 & 63,828 & 521 & 11,600 & 151 & 3,380 \\
\hline HI 37A & 50 & 5,378 & 94 & 2,440 & 43 \\
\hline HI 39A & 100 & 1,224 & 43 & 755 & 26 \\
\hline $\mathrm{HI} 46 \mathrm{~A}$ & 67 & 11,108 & 261 & 4,700 & 110 \\
\hline SM 238-190 & 690 & 940 & 227 & 545 & 132 \\
\hline SM 23G & 700 & 876 & 215 & 374 & 92 \\
\hline SM 268A & 10,500 & 569 & 2,090 & 236 & 868 \\
\hline SM 33D & 720 & 289 & 73 & 162 & 41 \\
\hline SM $40 \mathrm{JA}$ & 8 & 582 & 2 & 2,290 & 6 \\
\hline SS 108D & 9,600 & 1,186 & 3,990 & 487 & 1,640 \\
\hline SS 157A & 1,040 & 1,108 & 404 & 625 & 228 \\
\hline SS 169C & 3,037 & 632 & 672 & 199 & 212 \\
\hline SS 182C & 4,643 & 376 & 612 & 99 & 161 \\
\hline SS 182E & 6,280 & 344 & 757 & 111 & 244 \\
\hline SS 189A & 1,047 & 711 & 261 & 286 & 105 \\
\hline SS $191 \mathrm{~B}$ & 1,700 & 974 & 580 & 448 & 267 \\
\hline SS 58A & 1,927 & 499 & 337 & 149 & 101 \\
\hline ST 148E & 1,311 & 1,038 & 477 & 403 & 185 \\
\hline ST 161A & 68 & 543 & 13 & 240 & 6 \\
\hline ST 164C & 1,355 & 372 & 177 & 168 & 80 \\
\hline ST 34A & 4,497 & 103 & 162 & 50 & 78 \\
\hline VR 164A & 245 & 583 & 50 & 283 & 24 \\
\hline VR 22B & 150 & 879 & 46 & 374 & 20 \\
\hline VR 119D & 7,436 & 1,448 & 3,770 & 832 & 2,170 \\
\hline WC $102 \mathrm{G}$ & 1,407 & 479 & 236 & 224 & 110 \\
\hline WC 110A & 213 & 663 & 49 & 341 & 25 \\
\hline
\end{tabular}




\begin{tabular}{|l|c|c|c|c|c|}
\hline Platform & $\begin{array}{c}\text { Discharge } \\
\text { Volume } \\
\text { (bbl/day) }\end{array}$ & $\begin{array}{c}\text { BOD } \\
\text { Concentration } \\
\text { (mg/L) }\end{array}$ & $\begin{array}{c}\text { BOD Loading } \\
\text { (lb/day) }\end{array}$ & $\begin{array}{c}\text { TOC } \\
\text { Concentration } \\
\text { (mg/L) }\end{array}$ & $\begin{array}{c}\text { TOC Loading } \\
\text { (lb/day) }\end{array}$ \\
\hline WC 130A & 401 & 804 & 113 & 324 & 46 \\
\hline WC 168A & 35 & 80 & 1 & 26 & 0 \\
\hline WC 170A & 1,300 & 198 & 90 & 89 & 40 \\
\hline WC 173K & 40 & 736 & 10 & 320 & 4 \\
\hline WC 215A & 1,290 & 826 & 373 & 356 & 161 \\
\hline WC 237A & 3 & 1,632 & 2 & 990 & 1 \\
\hline WC 53A & 292 & 167 & 17 & 72 & 7 \\
\hline WC 65JA & 1,509 & 389 & 206 & 62 & 33 \\
\hline WC 71D & 135 & 494 & 23 & 206 & 10 \\
\hline WD 45A & 2,984 & 477 & 498 & 176 & 184 \\
\hline WD 73A & 20,159 & 365 & 2,580 & 134 & 948 \\
\hline WD 89A & 5,000 & 654 & 1,150 & 110 & 193 \\
\hline Total & 175,510 & & 36,000 & & 14,100 \\
\hline
\end{tabular}

Table 18 - Loading Estimates for Nitrate and Nitrite

\begin{tabular}{|l|c|c|c|c|c|}
\hline Platform & $\begin{array}{c}\text { Discharge } \\
\text { Volume } \\
\text { (bbl/day) }\end{array}$ & $\begin{array}{c}\text { Nitrate } \\
\text { Concentration } \\
\text { (mg/L) }\end{array}$ & $\begin{array}{c}\text { Nitrate } \\
\text { Loading } \\
\text { (lb/day) }\end{array}$ & $\begin{array}{c}\text { Nitrite } \\
\text { Concentration } \\
\text { (mg/L) }\end{array}$ & $\begin{array}{c}\text { Nitrite } \\
\text { Loading } \\
\text { (lb/day) }\end{array}$ \\
\hline EC 46B & 4,200 & 2.00 & 2.94 & 0.05 & 0.07 \\
\hline EC 47JP & 610 & 1.07 & 0.23 & 0.05 & 0.01 \\
\hline EC 49B & 63 & 1.80 & 0.04 & 0.05 & 0.00 \\
\hline EI 107A & 1,600 & 0.60 & 0.34 & 0.05 & 0.03 \\
\hline EI 128A-JC & 2,050 & 1.70 & 1.22 & 0.05 & 0.04 \\
\hline EI 172A & 67 & 4.00 & 0.09 & 0.05 & 0.00 \\
\hline EI 175B & 1,445 & 2.80 & 1.42 & 0.05 & 0.03 \\
\hline EI 184A & 5,591 & 0.60 & 1.17 & 0.05 & 0.10 \\
\hline EI 50-1 & 267 & 0.60 & 0.06 & 0.05 & 0.00 \\
\hline EI 57A & 2,250 & 0.60 & 0.47 & 0.05 & 0.04 \\
\hline EI 74A & 190 & 0.90 & 0.06 & 0.05 & 0.00 \\
\hline EI 95F & 1,410 & 1.27 & 0.63 & 0.05 & 0.02 \\
\hline GI 19\#3 & 63,828 & 0.83 & 18.6 & 0.05 & 1.12 \\
\hline HI 37A & 50 & 12.50 & 0.22 & 0.05 & 0.00 \\
\hline HI 39A & 100 & 15.80 & 0.55 & 0.05 & 0.00 \\
\hline HI 46A & 67 & 0.60 & 0.01 & 0.05 & 0.00 \\
\hline SM 238-190 & 690 & 1.40 & 0.34 & 0.05 & 0.01 \\
\hline SM 23G & 700 & 1.20 & 0.29 & 0.05 & 0.01 \\
\hline SM 268A & 10,500 & 1.47 & 5.39 & 0.05 & 0.18 \\
\hline SM 33D & 720 & 0.60 & 0.15 & 0.05 & 0.01 \\
\hline SM 40 JA & 8 & 0.80 & 0.00 & 0.05 & 0.00 \\
\hline SS 108D & 9,600 & 1.67 & 5.60 & 0.05 & 0.17 \\
\hline SS 157A & 1,040 & 1.90 & 0.69 & 0.05 & 0.02 \\
\hline SS 169C & 3,037 & 1.37 & 1.45 & 0.05 & 0.05 \\
\hline SS 182C & 4,643 & 1.00 & 1.63 & 0.05 & 0.08 \\
\hline
\end{tabular}




\begin{tabular}{|l|c|c|c|c|c|}
\hline Platform & $\begin{array}{c}\text { Discharge } \\
\text { Volume } \\
\text { (bbl/day) }\end{array}$ & $\begin{array}{c}\text { Nitrate } \\
\text { Concentration } \\
\text { (mg/L) }\end{array}$ & $\begin{array}{c}\text { Nitrate } \\
\text { Loading } \\
\text { (lb/day) }\end{array}$ & $\begin{array}{c}\text { Nitrite } \\
\text { Concentration } \\
\text { (mg/L) }\end{array}$ & $\begin{array}{c}\text { Nitrite } \\
\text { Loading } \\
\text { (lb/day) }\end{array}$ \\
\hline SS 182E & 6,280 & 0.60 & 1.32 & 0.05 & 0.11 \\
\hline SS 189A & 1,047 & 0.70 & 0.26 & 0.05 & 0.02 \\
\hline SS 191 B & 1,700 & 1.00 & 0.60 & 0.05 & 0.03 \\
\hline SS 58A & 1,927 & 0.70 & 0.47 & 0.05 & 0.03 \\
\hline ST 148E & 1,311 & 3.05 & 1.40 & 0.05 & 0.02 \\
\hline ST 161A & 68 & 1.10 & 0.03 & 0.05 & 0.00 \\
\hline ST 164C & 1,355 & 0.70 & 0.33 & 0.05 & 0.02 \\
\hline ST 34A & 4,497 & 0.60 & 0.94 & 0.05 & 0.08 \\
\hline VR 164A & 245 & 11.22 & 0.96 & 0.055 & 0.00 \\
\hline VR 22B & 150 & 2.40 & 0.13 & 0.05 & 0.00 \\
\hline VR 119D & 7,436 & 0.80 & 2.08 & 0.05 & 0.13 \\
\hline WC 102G & 1,407 & 1.53 & 0.76 & 0.05 & 0.02 \\
\hline WC 110A & 213 & 1.60 & 0.12 & 0.05 & 0.00 \\
\hline WC 130A & 401 & 1.40 & 0.20 & 0.05 & 0.01 \\
\hline WC 168A & 35 & 4.40 & 0.05 & 0.05 & 0.00 \\
\hline WC 170A & 1,300 & 0.60 & 0.27 & 0.05 & 0.02 \\
\hline WC 173K & 40 & 4.20 & 0.06 & 0.05 & 0.00 \\
\hline WC 215A & 1,290 & 0.60 & 0.27 & 0.05 & 0.02 \\
\hline WC 237A & 3 & 4.30 & 0.00 & 0.05 & 0.00 \\
\hline WC 53A & 292 & 0.80 & 0.08 & 0.05 & 0.01 \\
\hline WC 65JA & 1,509 & 0.70 & 0.37 & 0.05 & 0.03 \\
\hline WC 71D & 135 & 0.60 & 0.03 & 0.05 & 0.00 \\
\hline WD 45A & 2,984 & 2.90 & 3.03 & 0.05 & 0.05 \\
\hline WD 73A & 20,159 & 1.40 & 9.88 & 0.05 & 0.35 \\
\hline WD 89A & 5,000 & 0.60 & 1.05 & 0.05 & 0.09 \\
\hline & & 68.3 & & 3.07 \\
\hline
\end{tabular}

Table 19 - Loading Estimates for Ammonia and TKN

\begin{tabular}{|l|c|c|c|c|c|}
\hline Platform & $\begin{array}{c}\text { Discharge } \\
\text { Volume } \\
\text { (bbl/day) }\end{array}$ & $\begin{array}{c}\text { Ammonia } \\
\text { Concentration } \\
(\mathbf{m g} / \mathbf{L})\end{array}$ & $\begin{array}{c}\text { Ammonia } \\
\text { Loading } \\
\text { (lb/day) }\end{array}$ & $\begin{array}{c}\text { TKN } \\
\text { Concentration } \\
(\mathbf{m g} / \mathbf{L})\end{array}$ & $\begin{array}{c}\text { TKN Loading } \\
\text { (lb/day) }\end{array}$ \\
\hline EC 46B & 4,200 & 115 & 169 & 122 & 179 \\
\hline EC 47JP & 610 & 33 & 7 & 40 & 9 \\
\hline EC 49B & 63 & 64 & 1 & 74 & 2 \\
\hline EI 107A & 1,600 & 78 & 44 & 92 & 52 \\
\hline EI 128A-JC & 2,050 & 21 & 15 & 24 & 17 \\
\hline EI 172A & 67 & 34 & 1 & 39 & 1 \\
\hline EI 175B & 1,445 & 35 & 18 & 37 & 19 \\
\hline EI 184A & 5,591 & 40 & 78 & 67 & 132 \\
\hline EI 50-1 & 267 & 50 & 5 & 59 & 6 \\
\hline EI 57A & 2,250 & 54 & 43 & 89 & 70 \\
\hline EI 74A & 190 & 103 & 7 & 111 & 7 \\
\hline EI 95F & 1,410 & 58 & 29 & 63 & 31 \\
\hline
\end{tabular}




\begin{tabular}{|c|c|c|c|c|c|}
\hline Platform & $\begin{array}{l}\text { Discharge } \\
\text { Volume } \\
\text { (bbl/day) }\end{array}$ & $\begin{array}{c}\text { Ammonia } \\
\text { Concentration } \\
(\mathrm{mg} / \mathrm{L})\end{array}$ & $\begin{array}{c}\text { Ammonia } \\
\text { Loading } \\
\text { (lb/day) }\end{array}$ & $\begin{array}{c}\text { TKN } \\
\begin{array}{c}\text { Concentration } \\
(\mathrm{mg} / \mathrm{L})\end{array} \\
\end{array}$ & $\begin{array}{c}\text { TKN Loading } \\
\text { (lb/day) }\end{array}$ \\
\hline GI 19\#3 & 63,828 & 93 & 2,090 & 98 & 2,180 \\
\hline HI 37A & 50 & 54 & 1 & 74 & 1 \\
\hline HI 39A & 100 & 75 & 3 & 82 & 3 \\
\hline HI 46A & 67 & 129 & 3 & 134 & 3 \\
\hline SM 238-190 & 690 & 86 & 21 & 106 & 26 \\
\hline SM 23G & 700 & 51 & 13 & 46 & 11 \\
\hline SM 268A & 10,500 & 121 & 445 & 128 & 471 \\
\hline SM 33D & 720 & 160 & 40 & 168 & 42 \\
\hline SM 40 JA & 8 & 48 & 0 & 50 & 0 \\
\hline SS 108D & 9,600 & 38 & 127 & 36 & 122 \\
\hline SS 157A & 1,040 & 59 & 21 & 64 & 23 \\
\hline SS 169C & 3,037 & 102 & 108 & 111 & 118 \\
\hline SS 182C & 4,643 & 100 & 163 & 110 & 179 \\
\hline SS 182E & 6,280 & 104 & 229 & 109 & 240 \\
\hline SS 189A & 1,047 & 16 & 6 & 17 & 6 \\
\hline SS $191 \mathrm{~B}$ & 1,700 & 69 & 41 & 80 & 48 \\
\hline SS 58A & 1,927 & 20 & 14 & 40 & 27 \\
\hline ST 148E & 1,311 & 183 & 84 & 192 & 88 \\
\hline ST 161A & 68 & 51 & 1 & 60 & 1 \\
\hline ST 164C & 1,355 & 27 & 13 & 36 & 17 \\
\hline ST 34A & 4,497 & 246 & 387 & 216 & 340 \\
\hline VR 164A & 245 & 32 & 3 & 42 & 4 \\
\hline VR 22B & 150 & 101 & 5 & 178 & 9 \\
\hline VR 119D & 7,436 & 27 & 71 & 37 & 97 \\
\hline WC $102 \mathrm{G}$ & 1,407 & 79 & 39 & 79 & 39 \\
\hline WC 110A & 213 & 98 & 7 & 120 & 9 \\
\hline WC 130A & 401 & 96 & 14 & 101 & 14 \\
\hline WC 168A & 35 & 16 & 0 & 17 & 0 \\
\hline WC 170A & 1,300 & 20 & 9 & 32 & 15 \\
\hline WC $173 \mathrm{~K}$ & 40 & 36 & 1 & 42 & 1 \\
\hline WC 215A & 1,290 & 109 & 49 & 113 & 51 \\
\hline WC 237A & 3 & 63 & 0 & 73 & 0 \\
\hline WC 53A & 292 & 43 & 4 & 56 & 6 \\
\hline WC 65JA & 1,509 & 140 & 74 & 154 & 81 \\
\hline WC 71D & 135 & 30 & 1 & 37 & 2 \\
\hline WD 45A & 2,984 & 81 & 84 & 84 & 88 \\
\hline WD 73A & 20,159 & 22 & 158 & 31 & 216 \\
\hline WD 89A & 5,000 & 15 & 26 & 20 & 35 \\
\hline Total & 175,510 & & 4,770 & & 5,140 \\
\hline
\end{tabular}


Table 20 - Loading Estimates for Orthophosphate and Total Phosphorus

\begin{tabular}{|c|c|c|c|c|c|}
\hline Platform & $\begin{array}{l}\text { Discharge } \\
\text { Volume } \\
\text { (bbl/day) } \\
\end{array}$ & $\begin{array}{c}\text { Orthophosphate } \\
\text { Concentration } \\
(\mathrm{mg} / \mathrm{L})\end{array}$ & $\begin{array}{l}\text { Orthophosphate } \\
\text { Loading (lb/day) }\end{array}$ & $\begin{array}{c}\text { Total P } \\
\text { Concentration } \\
(\mathbf{m g} / \mathrm{L}) \\
\end{array}$ & $\begin{array}{c}\text { Total P } \\
\text { Loading } \\
\text { (lb/day) }\end{array}$ \\
\hline EC 46B & 4,200 & 0.50 & 0.74 & 0.62 & 0.91 \\
\hline EC 47JP & 610 & 2.87 & 0.61 & 5.30 & 1.13 \\
\hline EC 49B & 63 & 0.27 & 0.01 & 0.50 & 0.01 \\
\hline EI 107A & 1,600 & 0.15 & 0.08 & 0.28 & 0.16 \\
\hline EI 128A-JC & 2,050 & 0.10 & 0.07 & 0.20 & 0.14 \\
\hline EI 172A & 67 & 0.10 & 0.00 & 0.20 & 0.00 \\
\hline EI 175B & 1,445 & 0.13 & 0.07 & 0.28 & 0.14 \\
\hline EI 184A & 5,591 & 0.27 & 0.53 & 0.40 & 0.78 \\
\hline EI 50-1 & 267 & 0.51 & 0.05 & 0.64 & 0.06 \\
\hline EI 57A & 2,250 & 0.10 & 0.08 & 0.20 & 0.16 \\
\hline EI 74A & 190 & 0.12 & 0.01 & 0.38 & 0.03 \\
\hline EI 95F & 1,410 & 0.18 & 0.09 & 0.31 & 0.15 \\
\hline GI 19\#3 & 63,828 & 0.33 & 7.38 & 0.58 & 13.0 \\
\hline HI 37A & 50 & 0.12 & 0.00 & 0.20 & 0.00 \\
\hline HI 39A & 100 & 0.10 & 0.00 & 0.36 & 0.01 \\
\hline HI 46A & 67 & 0.10 & 0.00 & 0.20 & 0.00 \\
\hline SM 238-190 & 690 & 0.10 & 0.02 & 0.22 & 0.05 \\
\hline SM 23G & 700 & 0.10 & 0.02 & 0.22 & 0.05 \\
\hline SM 268A & 10,500 & 0.19 & 0.70 & 0.35 & 1.30 \\
\hline SM 33D & 720 & 0.26 & 0.07 & 0.30 & 0.08 \\
\hline SM 40 JA & 8 & 0.11 & 0.00 & 0.30 & 0.00 \\
\hline SS 108D & 9,600 & 0.30 & 1.02 & 0.41 & 1.39 \\
\hline SS 157A & 1,040 & 0.12 & 0.04 & 0.26 & 0.09 \\
\hline SS 169C & 3,037 & 0.28 & 0.30 & 0.40 & 0.43 \\
\hline SS $182 \mathrm{C}$ & 4,643 & 0.15 & 0.25 & 0.28 & 0.46 \\
\hline SS 182E & 6,280 & 0.10 & 0.22 & 0.20 & 0.44 \\
\hline SS 189A & 1,047 & 0.15 & 0.06 & 0.32 & 0.12 \\
\hline SS $191 \mathrm{~B}$ & 1,700 & 0.10 & 0.06 & 0.20 & 0.12 \\
\hline SS 58A & 1,927 & 0.17 & 0.11 & 2.42 & 1.63 \\
\hline ST 148E & 1,311 & 0.12 & 0.05 & 0.26 & 0.12 \\
\hline ST 161A & 68 & 0.10 & 0.00 & 0.20 & 0.00 \\
\hline ST 164C & 1,355 & 2.80 & 1.33 & 3.00 & 1.42 \\
\hline ST 34A & 4,497 & 0.16 & 0.25 & 0.28 & 0.44 \\
\hline VR 164A & 245 & 0.14 & 0.01 & 0.24 & 0.02 \\
\hline VR 22B & 150 & 0.10 & 0.01 & 0.20 & 0.01 \\
\hline VR 119D & 7,436 & 0.41 & 1.08 & 0.66 & 1.72 \\
\hline WC $102 \mathrm{G}$ & 1,407 & 0.10 & 0.05 & 1.33 & 0.65 \\
\hline WC 110A & 213 & 0.16 & 0.01 & 0.25 & 0.02 \\
\hline WC 130A & 401 & 0.10 & 0.01 & 0.10 & 0.01 \\
\hline WC 168A & 35 & 0.20 & 0.00 & 0.27 & 0.00 \\
\hline WC 170A & 1,300 & 0.10 & 0.05 & 0.20 & 0.09 \\
\hline WC $173 \mathrm{~K}$ & 40 & 0.10 & 0.00 & 0.20 & 0.00 \\
\hline WC 215A & 1,290 & 6.60 & 2.98 & 7.90 & 3.57 \\
\hline WC 237A & 3 & 0.11 & 0.00 & 0.12 & 0.00 \\
\hline
\end{tabular}




\begin{tabular}{|c|c|c|c|c|c|}
\hline Platform & $\begin{array}{c}\text { Discharge } \\
\text { Volume } \\
\text { (bbl/day) }\end{array}$ & $\begin{array}{c}\text { Orthophosphate } \\
\text { Concentration } \\
\text { (mg/L) }\end{array}$ & $\begin{array}{c}\text { Total P } \\
\text { Orthophosphate } \\
\text { Loading (lb/day) }\end{array}$ & $\begin{array}{c}\text { Total P } \\
\text { Concentration } \\
\text { (mg/L) }\end{array}$ & $\begin{array}{c}\text { Loading } \\
\text { (lb/day) }\end{array}$ \\
\hline WC 53A & 292 & 0.10 & 0.01 & 0.26 & 0.03 \\
\hline WC 65JA & 1,509 & 0.18 & 0.10 & 0.73 & 0.38 \\
\hline WC 71D & 135 & 0.22 & 0.01 & 0.40 & 0.02 \\
\hline WD 45A & 2,984 & 1.05 & 1.10 & 1.50 & 1.57 \\
\hline WD 73A & 20,159 & 0.39 & 2.78 & 0.61 & 4.33 \\
\hline WD 89A & 5,000 & 0.10 & 0.18 & 0.22 & 0.39 \\
\hline Total & 175,510 & & 22.6 & & 37.6 \\
\hline
\end{tabular}

The previous chapter discussed the impact of outliers and how they might influence overall averages. The approach used in this chapter calculated mass loading separately for each platform. In most instances, the platforms that exhibited outlier concentrations also had relatively low discharge volumes. This means that the calculated mass loadings for those platforms were relatively low and were not counted beyond their reasonable contribution. The effect of this process is to "flow weight" the relative contribution of each discharge. The few platforms that had the highest discharge volumes generally had concentrations that were near or below the mean or median of the data sets. One exception to this trend is the ammonia and TKN results for the high-volume platforms, which were higher than the mean.

\section{Extrapolation of Results to Full Hypoxic Zone}

The discharge volumes and loadings in Tables 17-20 represent the contributions of the 50 platforms that were sampled. These are believed to be representative of the full set of hypoxic zone platforms with produced water discharges in terms of the range of concentrations and discharge volumes. In fact, they may err on the side of conservatism for the following reasons:

- Any values reported by the laboratory as "less than X" were counted as being equal to "X," and

- Outlier concentrations for the analyzed parameters were not excluded.

One way of extrapolating the results from Tables 17-20 to estimate produced water discharges and their mass loadings to the full hypoxic zone is to compare the total discharge volume of the 50 sampled platforms with the total discharge volume for the entire hypoxic zone. Unfortunately, the discharge volume for the entire hypoxic zone is not readily available in any of the agency records or databases. It may be available for extraction from hundreds of individual paper files (NPDES Permit Discharge Monitoring Reports submitted by each operator) in the EPA Region 6 offices, but that effort was not practical for this short-timetable project.

An alternative approach is to assume that the volume of produced water generated from the lease blocks located within the hypoxic zone is a reasonable approximation of the volume of produced water actually discharged there. The MMS has records of the produced water generation by lease block (see Appendix E). For 2003, the total water produced from oil zones was $125,122,378 \mathrm{bbl}$, the total water from gas zones was $60,199,843 \mathrm{bbl}$, and the total water produced in the hypoxic zone was $185,322,221 \mathrm{bbl}$. Further assuming that the volume is equally 
distributed throughout the year, the average daily volume was $507,732 \mathrm{bbl} /$ day for the entire hypoxic zone.

This volume is 2.89 times the volume represented by the 50 sampled platforms $(175,510 \mathrm{bbl} /$ day). The loadings from Tables $17-20$ can be extrapolated upward by a factor of 2.89 to estimate the total loading for the entire hypoxic zone. Table 21 shows the full loading estimates.

Table 21 - Extrapolation of Loading Estimates to Entire Hypoxic Zone

\begin{tabular}{|l|c|c|}
\hline Parameter & $\begin{array}{c}\text { Loading from Sampled } \\
\text { Platforms (lb/day) }\end{array}$ & $\begin{array}{c}\text { Estimated Loading for Entire } \\
\text { Hypoxic Zone (lb/day) }\end{array}$ \\
\hline BOD & 36,000 & 104,100 \\
\hline TOC & 14,100 & 40,700 \\
\hline Nitrate & 68.3 & 197 \\
\hline Nitrite & 3.07 & 9 \\
\hline Ammonia & 4,770 & 13,800 \\
\hline TKN & 5,140 & 14,900 \\
\hline Orthophosphate & 22.6 & 65 \\
\hline Total phosphorus & 37.6 & 109 \\
\hline
\end{tabular}

\section{$\underline{\text { Perspective on Relative Contributions }}$}

The mass loading of oxygen demand and nutrients from produced water discharges to the hypoxic zone is substantial. Although these numbers appear large, they should be considered in the context of the volume of the hypoxic zone, which is estimated as being $17,000 \mathrm{~km}^{2}$ in area and an average of $17 \mathrm{~m}$ deep. This gives a hypoxic zone volume of $289 \mathrm{~km}^{3}\left(2.9 \times 10^{11} \mathrm{~m}^{3}\right.$, or $2.9 \times 10^{14}$ liters). A discharge loading of $104,000 \mathrm{lb}$ of BOD, if assumed to be evenly diluted throughout the entire hypoxic zone, would contribute only $0.17 \mu \mathrm{g} / \mathrm{L}$, or $0.17 \mathrm{ppb}$, of additional BOD. The weight of all that water is an equally impressive number. Assuming a weight of $2.2 \mathrm{lb} / \mathrm{L}$ (this is the weight of fresh water - salt water is slightly heavier), this equals $6.4 \times 10^{14} \mathrm{lb}$.

Another important feature is the location at which the produced water is discharged. Virtually all offshore platforms discharge to open ocean environments that are subject to wind and wave action. Discharges that are made anywhere near the surface will receive abundant reoxygenation due to the natural processes. The OOC database included data on the produced water discharge locations. Table 22 shows the percentage of platforms at relatively shallow depths - more than half discharge at or above the surface of the ocean. About 93 percent discharge in the top 20 feet of the water column. This should provide effective mitigation for some of the oxygendemanding pollutants. 
Table 22 - Data on Depth of Discharge Locations

\begin{tabular}{|l|c|c|}
\hline $\begin{array}{l}\text { Depth (ft) of Discharge } \\
\text { Location }\end{array}$ & No. of Platforms & $\begin{array}{c}\text { \% of Platforms from OOC } \\
\text { Database }\end{array}$ \\
\hline 0 or above the surface & 154 & 54 \\
\hline$<5$ & 204 & 71 \\
\hline$<10$ & 249 & 87 \\
\hline$<20$ & 267 & 93 \\
\hline
\end{tabular}

Another important point of perspective is a comparison of the produced water discharge mass loadings to the mass loading of key pollutants from the Mississippi and Atchafalaya Rivers. (Table 23). The riverine loadings are estimated from a National Oceanic and Atmospheric Administration report, Goolsby et al. (1999). ${ }^{2}$ That report expresses fluxes in metric tons per year.

Table 23 - Comparison of Nutrient Loadings from Produced Water Discharges and Riverine Inputs

\begin{tabular}{|l|c|c|c|}
\hline Nutrient & $\begin{array}{c}\text { Mean Flux (lb/yr) from } \\
\text { Mississippi and } \\
\text { Atchafalaya Rivers } \\
\text { (Goolsby et al. 1999) }\end{array}$ & $\begin{array}{c}\text { Estimated Annual Mass } \\
\text { Loading (lb/yr) from Produced } \\
\text { Water Discharges to the } \\
\text { Hypoxic Zone }\end{array}$ & $\begin{array}{c}\text { Ratio of Produced } \\
\text { Water Loading to } \\
\text { Riverine Loading }\end{array}$ \\
\hline Ammonia & $68,355,000$ & $5,030,000$ & a \\
\hline Organic N & $1,278,900,000$ & 389,000 & a \\
\hline Nitrate & $2,100,000,000$ & 71,900 & a \\
\hline Nitrite & 0 & 3,285 & 0.00159 \\
\hline Total N & $3,460,000,000$ & $5,500,000$ & a \\
\hline Orthophosphate & $92,100,000$ & 23,700 & a \\
\hline $\begin{array}{l}\text { Particulate } \\
\text { phosphate }\end{array}$ & $209,000,000$ & 0 & 0.00013 \\
\hline Total P & $301,000,000$ & 39,800 & a \\
\hline
\end{tabular}

${ }^{\mathrm{a}}$ The key ratios are total nitrogen and total phosphorus. Ratios for the other component comparisons are not shown.

The produced water discharge loadings are several orders of magnitude smaller than those entering the Gulf of Mexico from the rivers. The total nitrogen loading is about 0.16 percent and the total phosphorus loading is about 0.013 percent of the loading coming from the rivers.

\footnotetext{
${ }^{2}$ Goolsby, Donald A., William A. Battaglin, Gregory B. Lawrence, Richard S. Artz, Brent T. Aulenbach, Richard P. Hooper, Dennis R. Keeney, and Gary J. Stensland. 1999. Flux and Sources of Nutrients in the MississippiAtchafalaya River Basin: Topic 3 Report for the Integrated Assessment on Hypoxia in the Gulf of Mexico. NOAA Coastal Ocean Program Decision Analysis Series No. 17. NOAA Coastal Ocean Program, Silver Spring, MD. 130 pp.
} 


\section{Chapter 6 - QA/QC Evaluation of Data}

AccuLab produced data in two different formats. First, for each sample, the laboratory produced a "Report of Analysis." These reports included sample identifiers and sample dates, laboratory receipt dates, and analysis dates. The reports also included the method identification as well as results and result units. Other information provided with these reports included the completed chain-of-custody form, the completed sample log sheet, and the laboratory's sample receipt checklist. Comments were also included, as necessary; however, laboratory QC information was not included in these reports. Secondly, the laboratory provided data in electronic format using Microsoft Excel spreadsheets. The spreadsheets included field and laboratory QC results. Raw data were not included in these deliverables.

\section{Data Quality Evaluation}

Sampling Precision: Approximately 12 percent of all samples collected for the project were collected in duplicate, meeting the established requirement of a minimum of 10 percent duplicates. With 82 samples, 10 pairs of field duplicates were taken. The target RPD was 25 percent. With the exception of dissolved and suspended BOD and TOC, the duplicates were analyzed for the same parameters as the samples. Field duplicate results for all parameters in 9 of the 10 duplicate pairs produced RPDs ranging from 0 to 24 percent. In one of the duplicate pairs, the RPD for TKN, o-phosphorus, and total phosphorus was 19, 70, and 38 percent, respectively. In addition, in two of the other duplicate pairs, total phosphorus was detected just above the MQL in one of the duplicate pairs, whereas it was undetected above the MQL in the other. With these minor exceptions, sampling precision was acceptable.

Analytical Precision: An MS/MSD pair was analyzed by the laboratory for every sample batch. For BOD measurements, an LCS/LCSD was analyzed. The target RPD was 25 percent.

Comparison of MS/MSD and LCS/LCSD results for the parameters revealed RPDs ranging from 0 to 19 percent. Analytical precision for the study was acceptable.

Bias: Approximately 26 percent of all locations sampled were accompanied by field blanks; this met the established requirement of a minimum of 25 percent field blanks. With the exception of BOD and TOC measurements, field blanks were subject to the same analyses as the samples. In only one case was a parameter detected in a blank at a concentration greater than the reported MQL. The parameter in this case, ammonia, was detected at a concentration of $0.014 \mathrm{mg} / \mathrm{L}$, slightly above the MQL $(0.01 \mathrm{mg} / \mathrm{L})$. With sample concentrations ranging between $5 \mathrm{mg} / \mathrm{L}$ and over $200 \mathrm{mg} / \mathrm{L}$, blank contamination in this one case is inconsequential.

LRBs were analyzed for all parameters. LRBs for BOD were equal to or less than the $0.2 \mathrm{mg} / \mathrm{L}$ reporting level. For all other parameters, LRB concentrations were below the MQL. Bias was acceptable for the data set.

Accuracy: MSs (or LCSs for BOD) were used to assess the accuracy of the analytical measurements. An MS (or LCS for BOD) was performed for every batch. In most cases, the samples used were from the produced water study. The target acceptance limits for recovery is $80-120$ percent of the spike concentration. With one exception, recoveries for the parameters 
ranged from 81 to 120 percent. In one case, TKN, percent recovery was slightly above the acceptance limit, at 126 percent. In this case, the LCS was under control. Hence, QC for the data analyzed within the batch associated with the TKN measurements was acceptable. Accuracy for the study as a whole was acceptable.

Representativeness: The initial sample set, taken from 50 platforms, and agreed to by all participants in the project, was determined to adequately represent the population of platforms in the hypoxic zone. These 50 platforms appear to cover approximately 35 percent of the total volume of produced water discharge to the hypoxic zone. Representativeness for the data set was acceptable.

Comparability: Comparability is a qualitative parameter that pertains to the confidence with which one data set can be compared to another and contribute to a common analysis and interpretation. Sample data should be comparable with other measurement data for similar sites under similar conditions. For example, data sets generated during the present study should be comparable to data collected previously. In order to be comparable, data sets must employ the same or similar methods and should be associated with similar levels of quality assurance and control. No prior data sets of sufficient quality were available to assess this parameter.

Completeness: Completeness is a measure of the amount of useable data obtained, expressed as a percentage of the number of useable measurements intended to be obtained (i.e., data that were planned to be collected). The degree to which a lack of completeness affects the outcome of a study is a function of many factors, and the intensity of effect due to incompleteness is best expressed as a qualitative measure. This QC measure is typically used therefore as a screening tool, with a value of 80 percent complete as a general rule of thumb.

The study focused on 50 platforms located within the hypoxic zone. There were cases where samples were initially taken incorrectly (e.g., placed in the incorrect sample bottle), where initial data produced qualitative results (e.g., original samples unexpectedly depleted oxygen in all BOD tests), where some measurements were inadvertently omitted by the laboratory (e.g., dissolved BOD and dissolved organic carbon were not run), or where an additional sample was required because original results showed high variation. In all these cases, replacement or additional samples were successfully collected and analyzed.

There were four cases where the initial sample $\mathrm{pH}$ measured by the laboratory was determined to be exceptionally low. The laboratory surmised that sample container caps may have been switched in the field, giving a falsely low $\mathrm{pH}$ for the sample. Sampling personnel on the platforms were subsequently advised to take care not to switch the caps. In addition, the $\mathrm{pH}$ of the next sample (for a three-sample platform) was compared to the $\mathrm{pH}$ of the initial sample. In all cases, the $\mathrm{pH}$ of the following samples was within the expected range. The laboratory also indicated in its report that, if the caps were switched, it is not believed that it would have a large effect on the other test results. These data, though so qualified by the laboratory, are usable.

There was one case in which data intended to be collected was not collected. In one instance where 3 samples were to be taken, the first two samples were successfully taken and analyzed, 
but the platform ceased produced water discharge before the planned third sample could be taken. This was the only instance in which a planned sample was not taken.

In addition to the above, all other samples taken were properly preserved, analyzed within hold time, and analyzed successfully in compliance with established QC criteria. Hence completeness is determined to be very nearly 100 percent.

Specific Issues: All laboratory Reports of Analysis indicated that "sample for $\mathrm{pH}$ was past maximum hold time when received at the laboratory." At the onset of the sampling program, the difficulty of having platform personnel take properly controlled $\mathrm{pH}$ measurements at all of the platforms was recognized. As a result, a decision was made to take this measurement at the laboratory, recognizing the holding time requirement could not be satisfied. As $\mathrm{pH}$ was not a key measurement for this study, the lab $\mathrm{pH}$ measurement was used, even if it was taken at a time later than desired. The impact on data quality is negligible.

Sample temperature was taken and recorded at the same time as $\mathrm{pH}$, sometime after samples had been removed from the cooler. The laboratory did not also record sample temperature on receipt (i.e., in the sample coolers) as required in AccuLab's Laboratory Quality Control Measures. However, the AccuLab Sample Receipt Checklist indicates whether the coolers were received with ice present. There was one case in which the coolers were received without ice, and this platform was resampled. All other coolers were received with ice present. Since ice was present in the coolers on receipt, sample temperatures are assumed to meet method requirements $\left(<4^{\circ} \mathrm{C}\right)$.

Logically, TKN measurements should produce results that are greater than or equal to ammonia concentrations in every case. However, in three instances, data were produced for which TKN concentrations were less than those of ammonia. In these cases, the laboratory reran the TKN analyses and generated TKN results that were greater than ammonia concentrations. These rerun TKN analyses were, however, run after the maximum sample holding times. The laboratory noted this information in the spreadsheets provided. The original data for these measurements were retained in the project database as flagged data.

\section{Conclusions of Data Evaluation}

With the minor exceptions noted above, the overall quality of the data collection activity was acceptable. 


\section{Chapter 7 - Findings and Conclusions}

The report describes and presents the results of a program to sample 50 offshore oil and gas platforms located within the Gulf of Mexico hypoxic zone. The program was conducted in response to a requirement in the EPA general NPDES permit for offshore oil and gas discharges (GMG290000). EPA desired information on the amount of oxygen-demanding substances contained in the produced water discharges. This information was needed as inputs to several water quality models that EPA intends to run to estimate the impact of the produced water discharges on the hypoxic zone.

The sampling program was completed successfully on a very short timetable. The logistics were complicated by:

- Working with 50 different facilities operated by more than 20 oil and gas companies,

- Dealing with offshore conditions and transportation issues, and

- Arranging timely transfer of collected samples from platforms to shore bases to couriers to the testing laboratory within a 48-hour period.

This involved frequent and extensive coordination among several agencies, the industry, two analytical laboratories, and Argonne National Laboratory.

The results show that there is variability over time at any given platform, but that the variability is not excessive. The study evaluated variability of BOD for 16 platforms that were tested more than once. All but one of these platforms (about 94 percent) passed the variability criterion established for the study. The one platform exhibiting excessive variability was sampled six times and was unable to show consistent results. The concentrations of BOD and the other oxygen-demanding materials vary from platform to platform, too. Most of the sample results fell within a fairly restricted range of values, but for each parameter, there were several outlier samples that had values much higher than the range for the rest of the samples.

The sampling provided average platform concentrations for each parameter. These were converted to mass loadings by multiplying by the discharge volume and a conversion factor. The mass loadings represent estimates of the $1 \mathrm{~b}$ /day of each parameter that are discharged from the 50 platforms. The total produced water discharge volume from the 50 platforms was $175,510 \mathrm{bbl} /$ day. The total amount of produced water generated in the hypoxic zone was estimated as 507,732 bbl/day. Finally, the mass loadings from produced water discharges to the entire hypoxic zone were estimated by multiplying the 50-platform loadings by the ratio of total water generated to 50-platform discharge volume.

The produced water discharge loadings estimated for the entire hypoxic zone are several orders of magnitude smaller than those entering the Gulf of Mexico from the Mississippi and Atchafalaya Rivers. The total nitrogen loading is about 0.16 percent and the total phosphorus loading is about 0.013 percent of the nutrient loading coming from the rivers. 
These estimates and the sampling data from 50 platforms represent the most complete and comprehensive effort ever undertaken to evaluate the oxygen-demanding parameters contained in produced water discharges. 


\section{Acknowledgments}

Argonne's work was sponsored by DOE's National Energy Technology Laboratory (NETL). Nancy Comstock is the NETL project officer. She and Nancy Johnson of DOE's Office of Fossil Energy participated in the planning meetings leading up to the sampling program and reviewed information throughout the study. We acknowledge the support and assistance of Margaret Metcalf from the MMS, who provided extensive data sets and maps that were used in selecting platforms.

This work was closely coordinated with API, the OOC, and more than 20 oil and gas companies and their support contractors. The companies that had their platforms sampled include: Apache, ATP, Bois D'Arc, BP, ChevronTexaco, Dominion, El Paso, Energy Resource Technology, ENI, ExxonMobil, Houston Exploration, Hunt Petroleum, Linder, Mariner, Newfield, Nexen, Northstar, Seneca, Stone, and W\&T Offshore. We thank the environmental coordinators, platform personnel, helicopter pilots, and shore base managers who contributed their time to make sure we got representative samples on schedule. In particular, we acknowledge the frequent guidance and assistance of Shell's Kent Satterlee, who is the chairman of the OOC Environmental Subcommittee, and ExxonMobil's Michael Parker, who served as liaison to API.

Finally, we acknowledge the contributions of Tony Albert of AccuLab and Richard Ricau and David Daniel of EEUSA. Without their hard work and extra effort, we would not have been able to accomplish all of the sampling included in this program in such a short amount of time. 


\section{Appendix A - Sampling Instructions for Produced Water Study}

\section{$\underline{\text { General Instructions }}$}

1. Environmental Enterprises will prepare and send sampling kits for this study prior to the start date. There will be three different kits used for this sampling project. All sampled sites will use the same basic kit. Ten percent of the sampled sites will include a field duplicate sample, and twenty-five percent of the sampled sites will include a field blank sample. When the kit or kits arrive, check the contents. Wear a pair of CLEAN gloves when handling any of the items in the kit.

\subsection{All kits will have:}

- 1 bottle marked BOD, Nitrate, Nitrite, ortho-Phosphate, Conductivity, Salinity, pH.

- 1 bottle marked TOC, TKN, Ammonia, Total Phosphorus. This bottle will contain a small amount of dilute sulfuric acid. Check to make sure the acid is present by holding the bottle to the light. Do not remove cap to look inside. The acid should be visible at the bottom of the bottle.

- 1 MSDS for sulfuric acid.

- 1 thermometer.

- 2 plastic bags.

- 2 Chain of Custody forms with instructions for completion on the back. One of the Chain of Custody forms will be an extra in case the first becomes unusable.

- 2 Sampling Log sheets with instructions for completion on the back. One of the Sampling Log sheets will be an extra in case the first becomes unusable.

1.2. If the kit includes collection of Field Duplicate samples, it will also have:

- 1 bottle marked FIELD DUPLICATE BOD, Nitrate, Nitrite, ortho-Phosphate, Conductivity, Salinity, $\mathrm{pH}$.

- 1 bottle marked FIELD DUPLICATE TOC, TKN, Ammonia, Total Phosphorus. This bottle will contain a small amount of dilute sulfuric acid. Check to make sure the acid is present by holding the bottle to the light. Do not remove cap to look inside. The acid should be visible at the bottom of the bottle.

1.3. If the kit includes collection of Field Blank samples, it will also have:

- 1 bottle marked FIELD BLANK BOD, Nitrate, Nitrite, Orthophosphate, Conductivity, Salinity, $\mathrm{pH}$.

- 1 bottle marked FIELD BLANK TOC, TKN, Ammonia, Total Phosphorus. This bottle will contain a small amount of dilute sulfuric acid. Check to make sure the acid is present by holding the bottle to the light. Do not remove cap to look inside. The acid should be visible at the bottom of the bottle.

- 2 bottles marked Deionized Water Lot Number mmddyyyy, which indicates the date that the deionized water was drawn. 
2. If any of the items listed above are missing, call Richard Ricau or other Sample Department personnel (Environmental Enterprises) at (800) 966-2788 or (985) 646-2787 to get instructions as to how to proceed.

Sampling Instructions (For actual samples, field duplicates, and field blanks, make sure you follow your company and facility health and safety plan.)

3. Please call Richard Ricau or other Sample Department personnel (Environmental Enterprises) at (800) 966-2788 or (985) 646-2787 to confirm scheduled pick up and coordinate delivery to AccuLab via Environmental Enterprises USA (EEUSA) pick up service, Federal Express, or Hot-Shot. If you have any questions about sample pick up, call Richard Ricau or other Sample Department personnel at (800) 966-2788 or (985) 646-2787.

4. If you have any questions about these instructions or if samples cannot be delivered to AccuLab within 36 hours of collection, please call Charmiane Albert or Erica Dragon (AccuLab) at (504) 371-8557.

5. Enter the requested general information on the Chain of Custody form if it has not already been entered. Refer to the instructions on the back of the Chain of Custody form.

6. Take the kit to the sample location where monthly produced water compliance samples are taken (overboard water discharge). If you are not already wearing gloves, put them on now.

7. Take the two sample bottles out of the kit and mark the sample location (area, block, platform) on each label in INDELIBLE ink (Sharpie or other similar pen).

7.1. If the kit includes collection of Field Duplicate samples, also take the two sample bottles marked FIELD DUPLICATE out of the kit and mark the sample location on each label in INDELIBLE ink (Sharpie or other similar pen).

7.2. If the kit includes collection of Field Blank samples, also take the two sample bottles marked FIELD BLANK out of the kit and mark the sample location on each label in INDELIBLE ink (Sharpie or other similar pen).

8. Open the sample spigot or needle valve and let the water run for at least 2 minutes to be sure that any stagnant water standing in the pipe or spigot is flushed.

9. Do not rinse any of the sample bottles. Collect a sample in the bottle marked TOC, TKN, Ammonia, Total Phosphorus. Fill the bottle to the bottom of the neck. TAKE SPECIAL CARE NOT TO OVERFLOW THE BOTTLE, AS IT CONTAINS ACID. Cap it tightly. Immediately after this, collect a sample in the bottle marked BOD, Nitrate, Nitrite, orthoPhosphate, Conductivity, Salinity, pH. Fill it to the bottom of the neck and cap it tightly.

9.1. If the kit includes collection of Field Duplicate samples, also collect samples in the two sample bottles marked FIELD DUPLICATE in the same way. 
9.2. If the kit includes collection of Field Blank samples, carefully pour the deionized water from one of the deionized water bottles into one of the bottles marked FIELD BLANK and the deionized water from the other bottle into the other bottle marked FIELD BLANK. This procedure provides a check on external contamination. DO NOT ADD ANY PRODUCED WATER TO THESE BOTTLES! REMEMBER TO TAKE CARE WHEN POURING THE DEIONIZED WATER INTO THE BOTTLE THAT CONTAINS ACID.

10. Dry off the outside of all filled sample bottles with a paper towel and cover the label with clear plastic tape.

11. Check the boxes on the Chain of Custody form under Testing Required \& Preservative. Circle YES or NO to indicate whether the sample kit included bottles for FIELD BLANK or FIELD DUPLICATE and whether you collected the required samples.

12. Within 15 minutes of when you collected the samples, and using the supplied thermometer, measure the temperature of the sample(s) marked BOD, Nitrate, Nitrite, ortho-Phosphate, Conductivity, Salinity, $\mathrm{pH}$. If possible, collect a portion of sample in a separate clean container, and analyze it rather than the sample itself. Record the results along with the date and time measured and your initials.

13. Enter the date and time the samples were collected and print and sign your name in the appropriate space on the Chain of Custody form. Complete the Sampling Log sheet, including date, time, and signature. An example of a completed sheet is shown on the back.

14. Chill the sample(s) in a refrigerator or an ice bath before packaging for transport.

14.1. In order to prevent water leakage, open plastic bags provided. Place newspapers or other absorbent material on the bottom of the ice chest. PLACE ONE

WATERPROOF BAG in the ice chest. Put the tightly capped sample containers in the second plastic bag and tie it off securely. Place the bag with the samples inside the other bag and fill the outside bag with ice. Close the outside plastic bag and TIE IT OFF SECURELY. Place newspapers or other absorbent material on top of the bags to absorb any condensation from inside the cooler.

14.2. Tape the ice chest closed but allow access to the chest for ice to be replenished at each transfer, if necessary.

14.3. Place the Chain of Custody and Sampling Log sheet in its Ziploc bag along with these instructions and tape the Ziploc bag to the outside of the ice chest. Make sure that the documents can be easily removed and replaced.

15. When you give the kit to someone (helicopter pilot, crew boat captain, shore base personnel), sign the Chain of Custody form and enter the date and time in the appropriate spaces. Refer to the instructions on the back of the Chain of Custody form, Steps 19 and 20. 
16. Explain to the person receiving the ice chest that he must sign the Chain of Custody form to receive the samples and that he must relinquish the ice chest for the next person, as you did.

17. Each person that takes custody of the sample(s) must complete his part of the COC (collected by \& relinquished by or received by \& relinquished by).

17.1. Shore base personnel should open the cooler upon receipt to replenish the ice in the cooler for the transport of the samples to the laboratory.

18. Remember that the samples MUST arrive at AccuLab within 36 hours of when they were collected. They should arrive within 24 hours, if possible. 


\section{Appendix B - Sampling Log Sheet}

THE PERSON COLLECTING THE SAMPLES SHOULD COMPLETE THIS FORM DURING THE SAMPLING ACTIVITY, MAKE A COPY FOR HIS/HER RECORDS, AND PLACE THE ORIGINAL IN THE ZIP LOCK BAG along With the Chain of CUSTOdy Form. PleAse PRINT NEATLY!

\section{Produced WATER STUdy - SAMPLing Log ENTRY ForM}

\begin{tabular}{|c|c|}
\hline \multirow{2}{*}{$\begin{array}{c}\text { ITEM } \\
\text { PLATFORM NAME/NUMBER }\end{array}$} & \multirow[t]{2}{*}{ LOG ENTRY } \\
\hline & \\
\hline $\begin{array}{l}\text { DATE/TIME SAMPLING } \\
\text { BEGAN }\end{array}$ & \\
\hline NAME OF LEAD SAMPLER & \\
\hline $\begin{array}{l}\text { NAME OF SUPPORT } \\
\text { SAMPLERS (IF ANY) }\end{array}$ & \\
\hline $\begin{array}{l}\text { WAS SAMPLING LOCATION } \\
\text { INDOORS OR OUTDOORS? }\end{array}$ & \\
\hline $\begin{array}{l}\text { IF OUTDOORS, INDICATE } \\
\text { WEATHER CONDITIONS? }\end{array}$ & \\
\hline SAMPLE ID - SAMPLE A & \\
\hline SAMPLE A TEMPERATURE & \\
\hline $\begin{array}{l}\text { OBSERVATIONS, SAMPLE A } \\
\text { (ClARITY, COLOR, ODOR, } \\
\text { ETC.) }\end{array}$ & \\
\hline SAMPLE ID - SAMPLE B & \\
\hline $\begin{array}{l}\text { OBSERVATIONS, SAMPLE } \\
\text { (CLARITY, COLOR, ODOR, } \\
\text { ETC.) }\end{array}$ & \\
\hline $\begin{array}{l}\text { IF FIELD DUPLICATE } \\
\text { SAMPLES ARE MADE, } \\
\text { PROVIDE SAMPLE IDS. }\end{array}$ & \\
\hline $\begin{array}{l}\text { IF FIELD BLANK SAMPLES } \\
\text { ARE MADE, PROVIDE SAMPLE } \\
\text { IDS. }\end{array}$ & \\
\hline $\begin{array}{l}\text { DESCRIBE GENERAL } \\
\text { SAMPLING PROCEDURE. }\end{array}$ & \\
\hline COMMENTS (NA IF NONE) & \\
\hline $\begin{array}{l}\text { DATE/TIME SAMPLING } \\
\text { ENDED }\end{array}$ & \\
\hline $\begin{array}{l}\text { SIGNATURE OF LEAD } \\
\text { SAMPLER }\end{array}$ & \\
\hline
\end{tabular}




\section{Appendix C - Chain-of-Custody Form}

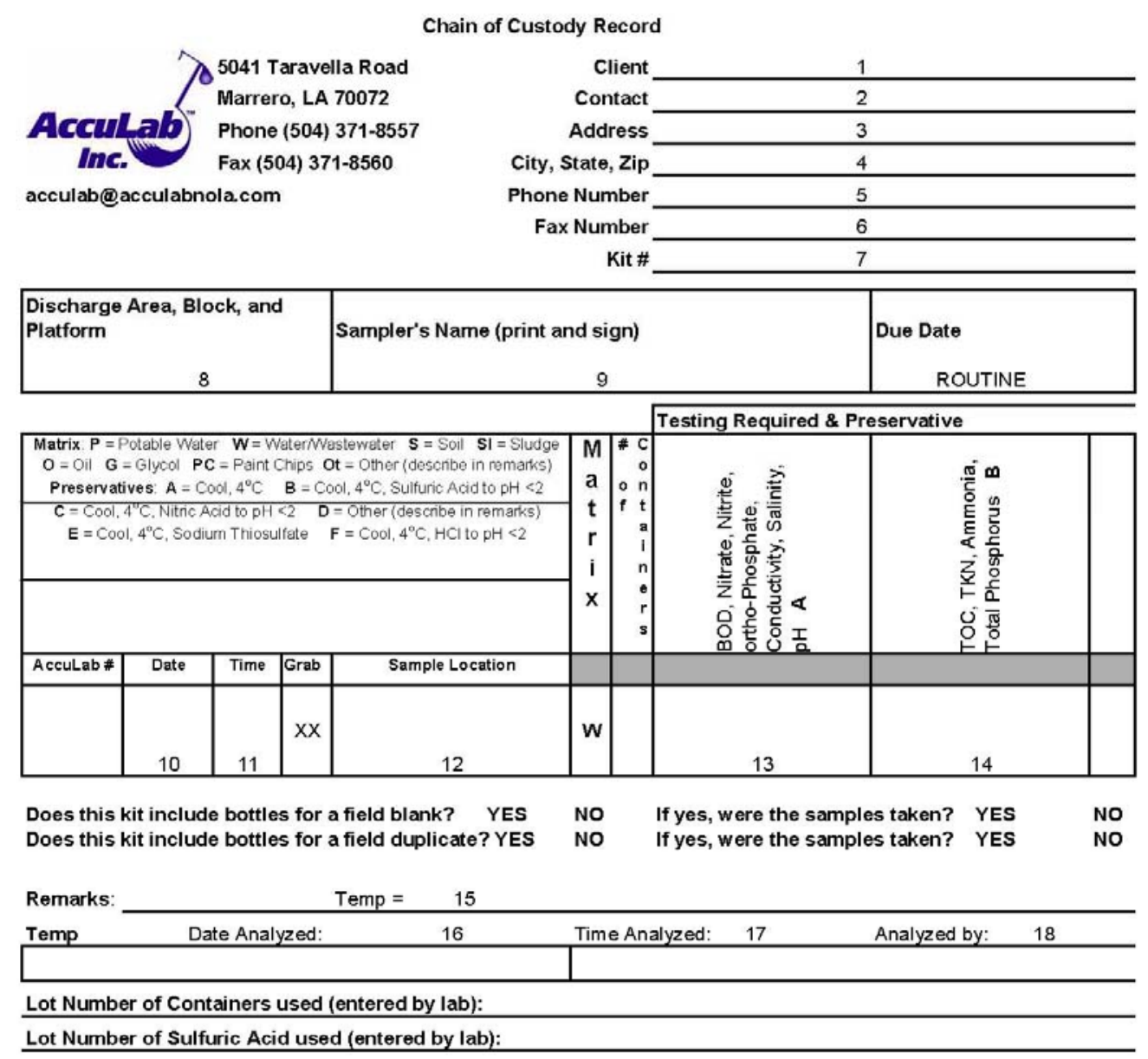

Lot Number of Sulfuric Acid used (entered by lab):

\begin{tabular}{|c|c|c|c|c|}
\hline \multicolumn{5}{|c|}{ Did you replenish the ice? } \\
\hline & & & Yes & No \\
\hline \begin{tabular}{|ll} 
Relinquished by (Signature) & 19
\end{tabular} & Date/Time 20 & Received By (Signature) & 22 & 23 \\
\hline Relinquished by (Signature) 24 & Date/Time 25 & Received By (Signature) & 27 & 28 \\
\hline Relinquished by (Signature) & Date/Time & Received By (Signature) & & \\
\hline Relinquished by (Signature) & Date/Time & Received By (Signature) & & \\
\hline Relinquished by (Signature) & Date/Time & Received for Lab By (Signature) & & \\
\hline & Samples on ice when receive & at lab? & & \\
\hline Relinquished by (Signature) & Date/Time & Received By (Signature) & & \\
\hline
\end{tabular}




\section{Appendix D - Sample Results}

Due to the large number of parameters, the results are split into two long tables. The first table (D-1) provides the details on platform location, operator, sampling date, BOD, and TOC. The second table (D-2) provides the results for all other parameters. Rather than repeat the full platform location data and sampling date, the second table uses only the platform ID as the identifier. 


\begin{tabular}{|c|c|c|c|c|c|c|c|c|c|}
\hline \multicolumn{10}{|c|}{ Table D-1 - Sample Results for BOD and TOC } \\
\hline $\begin{array}{l}\text { Block \& } \\
\text { Platform }\end{array}$ & Operator & Lease & $\begin{array}{l}\text { Sample } \\
\text { Date }\end{array}$ & $\begin{array}{l}\text { BOD, } \\
\mathrm{mg} / \mathrm{L}\end{array}$ & $\begin{array}{c}\text { Dissolved } \\
\text { BOD, mg/L }\end{array}$ & $\begin{array}{l}\text { Suspended } \\
\text { BOD, mg/L }\end{array}$ & $\begin{array}{l}\text { TOC, } \\
\mathrm{mg} / \mathrm{L}\end{array}$ & $\begin{array}{l}\text { Dissolved } \\
\text { TOC, mg/L }\end{array}$ & $\begin{array}{l}\text { Suspended } \\
\text { TOC, mg/L }\end{array}$ \\
\hline EC 46B & Stone Energy & 3288 & $6 / 1 / 2005$ & 732 & NA & NA & 412 & NA & NA \\
\hline EC 47JP & Newfield & $\begin{array}{l}00768- \\
47,48 a\end{array}$ & $2 / 23 / 2005$ & 1335 & NA & NA & 765 & NA & NA \\
\hline EC 47JP & Newfield & $\begin{array}{c}0076847 \\
48 a\end{array}$ & $3 / 16 / 2005$ & 787 & NA & NA & 480 & NA & NA \\
\hline EC 47JP & Newfield & $\begin{array}{c}0076847 \\
48 a\end{array}$ & 4/13/2005 & 740 & NA & NA & 450 & NA & NA \\
\hline EC 49B & Newfield & 01364 & $5 / 18 / 2005$ & 1200 & 1128 & 72 & 630 & 620 & 10 \\
\hline El 107A & Apache & G15241 & $2 / 25 / 2005$ & 330 & NA & NA & 97.0 & NA & NA \\
\hline El 107A & Apache & G15241 & $3 / 16 / 2005$ & 200 & $\mathrm{NA}$ & $\mathrm{NA}$ & 440 & $\mathrm{NA}$ & $\mathrm{NA}$ \\
\hline El 107A & Apache & G15241 & 4/21/2005 & 213 & $\mathrm{NA}$ & $\mathrm{NA}$ & 43.0 & $\mathrm{NA}$ & NA \\
\hline El 128A-JC & $\begin{array}{c}\text { Energy Res. } \\
\text { Tech }\end{array}$ & $\begin{array}{l}\text { OCS } \\
0442\end{array}$ & 4/26/2005 & 415 & NA & NA & 86 & NA & NA \\
\hline El 172A & Newfield & 5494 & $5 / 18 / 2005$ & 1821 & $\mathrm{NA}$ & $\mathrm{NA}$ & 720 & $\mathrm{NA}$ & $\mathrm{NA}$ \\
\hline El 175B & Apache & G00438 & $5 / 26 / 2005$ & 392 & NA & NA & 172 & $\mathrm{NA}$ & NA \\
\hline El 184A & Newfield & 5498 & $5 / 18 / 2005$ & 628 & $\mathrm{NA}$ & $\mathrm{NA}$ & 178 & $\mathrm{NA}$ & $\mathrm{NA}$ \\
\hline EI 50-1 & Hunt Petroleum & G17960 & $4 / 20 / 2005$ & 147 & $\mathrm{NA}$ & NA & 4880 & $\mathrm{NA}$ & $\mathrm{NA}$ \\
\hline El 57A & $\begin{array}{l}\text { Northstar } \\
\text { Gulfsand }\end{array}$ & 2601 & $5 / 12 / 2005$ & 503 & NA & NA & 325 & NA & NA \\
\hline El 74A & $\begin{array}{c}\text { Chevron } \\
\text { Texaco }\end{array}$ & G02099 & $5 / 18 / 2005$ & 442 & NA & NA & 174 & NA & NA \\
\hline El 95F & W\&T Offshore & 0046 & $2 / 25 / 2005$ & 150 & $\mathrm{NA}$ & $\mathrm{NA}$ & 50.0 & $\mathrm{NA}$ & NA \\
\hline El 95F & W\&T Offshore & 0046 & $3 / 24 / 2005$ & 214 & $\mathrm{NA}$ & NA & 122 & $\mathrm{NA}$ & NA \\
\hline El 95F & W\&T Offshore & 0046 & $4 / 21 / 2005$ & 79 & NA & NA & $<50$ & NA & NA \\
\hline GI 19\# 3 & ExxonMobil & 00033 & $2 / 21 / 2005$ & 488 & NA & NA & 122 & NA & NA \\
\hline GI 19\#3 & ExxonMobil & 00033 & $3 / 15 / 2005$ & 482 & $\mathrm{NA}$ & $\mathrm{NA}$ & 152 & $\mathrm{NA}$ & NA \\
\hline GI 19\#3 & ExxonMobil & 00033 & $4 / 19 / 2005$ & 592 & 535 & 57 & 179 & 169 & 10 \\
\hline $\mathrm{HI} 37 \mathrm{~A}$ & Seneca & G15769 & $5 / 31 / 2005$ & 5378 & NA & NA & 2440 & NA & NA \\
\hline $\mathrm{HI} 39 \mathrm{~A}$ & Houston Expl & 04078 & $5 / 25 / 2005$ & 1224 & NA & NA & 755 & $\mathrm{NA}$ & NA \\
\hline $\mathrm{HI} 46 \mathrm{~A}$ & Mariner & G24404 & $5 / 24 / 2005$ & 11108 & $\mathrm{NA}$ & $\mathrm{NA}$ & 4700 & $\mathrm{NA}$ & $\mathrm{NA}$ \\
\hline SM 238-190 & El Paso Prod & 00310 & $5 / 23 / 2005$ & 940 & NA & NA & 545 & $\mathrm{NA}$ & NA \\
\hline SM 268A & Apache & G02310 & $2 / 24 / 2005$ & 626 & NA & NA & 224 & $\mathrm{NA}$ & NA \\
\hline SM 268A & Apache & G02310 & $4 / 13 / 2005$ & 578 & 432 & 146 & 248 & 121 & 127 \\
\hline SM 40JA & Hunt Petroleum & G13607 & $4 / 21 / 2005$ & 582 & NA & NA & 2290 & NA & NA \\
\hline SMI 23G & Devon Energy & G00778 & $5 / 11 / 2005$ & 876 & $\mathrm{NA}$ & NA & 374 & $\mathrm{NA}$ & NA \\
\hline
\end{tabular}




\begin{tabular}{|c|c|c|c|c|c|c|c|c|c|}
\hline \multicolumn{10}{|c|}{ Table D-1 - Sample Results for BOD and TOC } \\
\hline $\begin{array}{l}\text { Block \& } \\
\text { Platform }\end{array}$ & Operator & Lease & $\begin{array}{c}\text { Sample } \\
\text { Date }\end{array}$ & $\begin{array}{l}\mathrm{BOD}, \\
\mathrm{mg} / \mathrm{L}\end{array}$ & $\begin{array}{l}\text { Dissolved } \\
\text { BOD, mg/L }\end{array}$ & $\begin{array}{l}\text { Suspended } \\
\text { BOD, mg/L }\end{array}$ & $\begin{array}{l}\text { TOC, } \\
\mathrm{mg} / \mathrm{L}\end{array}$ & $\begin{array}{l}\text { Dissolved } \\
\text { TOC, mg/L }\end{array}$ & $\begin{array}{l}\text { Suspended } \\
\text { TOC, mg/L }\end{array}$ \\
\hline SMI 268A & Apache & G02310 & $3 / 16 / 2005$ & 504 & NA & NA & 236 & NA & NA \\
\hline SMI 33D & Apache & G00780 & $5 / 5 / 2005$ & 289 & 233 & 56 & 162 & 156 & 6 \\
\hline SS 108D & ChevronTexaco & 00814 & $3 / 29 / 2005$ & 1392 & NA & NA & 730 & NA & NA \\
\hline SS 108D & ChevronTexaco & 00814 & $4 / 19 / 2005$ & 1155 & NA & NA & 590 & $\mathrm{NA}$ & NA \\
\hline SS 157A & Newfield & 8709 & $5 / 23 / 2005$ & 1108 & NA & NA & 625 & NA & NA \\
\hline SS 169C & ChevronTexaco & 00820 & $3 / 24 / 2005$ & 561 & NA & NA & 186 & NA & NA \\
\hline SS 169C & ChevronTexaco & 00820 & $4 / 19 / 2005$ & 656 & NA & NA & 254 & NA & NA \\
\hline SS 182C & ChevronTexaco & 00821 & $3 / 24 / 2005$ & 331 & NA & NA & 116 & NA & NA \\
\hline SS 182C & ChevronTexaco & 00821 & $4 / 19 / 2005$ & 432 & NA & NA & 119 & NA & NA \\
\hline SS 182E & $\begin{array}{c}\text { Chevron } \\
\text { Texaco }\end{array}$ & G01019 & $5 / 17 / 2005$ & 344 & 328 & 16 & 111 & NA & NA \\
\hline SS 189A & Apache & G04232 & $5 / 17 / 2005$ & 711 & NA & NA & 286 & NA & NA \\
\hline SS 191B & Hunt Pet. & G22713 & $4 / 28 / 2005$ & 974 & NA & NA & 448 & NA & NA \\
\hline SS 58A & Newfield & G07746 & $2 / 23 / 2005$ & 636 & NA & NA & 87.5 & NA & NA \\
\hline SS 58A & Newfield & G07746 & $3 / 16 / 2005$ & 350 & NA & NA & 74 & $\mathrm{NA}$ & NA \\
\hline SS 58A & Newfield & G07746 & $4 / 13 / 2005$ & 512 & NA & NA & 286 & NA & NA \\
\hline SS108D & ChevronTexaco & 00814 & $2 / 23 / 2005$ & 1010 & NA & NA & 140 & NA & NA \\
\hline SS169C & ChevronTexaco & 00820 & $2 / 23 / 2005$ & 678 & 555 & 123 & 157 & 107 & 50 \\
\hline SS182C & ChevronTexaco & 00821 & $2 / 23 / 2005$ & 366 & NA & NA & 62.0 & NA & NA \\
\hline ST 148E & Newfield & G01898 & $2 / 23 / 2005$ & 1134 & NA & NA & 140 & NA & NA \\
\hline ST 148E & Newfield & G01898 & $3 / 16 / 2005$ & 942 & NA & NA & 665 & NA & NA \\
\hline ST 161A & Apache & G01248 & $5 / 12 / 2005$ & 543 & NA & NA & 240 & $\mathrm{NA}$ & NA \\
\hline ST 164C & Stone Energy & 1250 & $5 / 10 / 2005$ & 372 & NA & NA & 168 & NA & NA \\
\hline ST 34A & Bois d'Arc & 4842 & $5 / 3 / 2005$ & 103 & NA & NA & 49.5 & NA & NA \\
\hline VR 119G & W\&T Offshore & 00487 & $3 / 4 / 2005$ & 1725 & NA & NA & 880 & NA & NA \\
\hline VR 119G & W\&T Offshore & 00487 & $3 / 24 / 2005$ & 1173 & NA & NA & 805 & NA & NA \\
\hline VR 119G & W\&T Offshore & 00487 & 4/21/2005 & 1446 & NA & NA & 810 & $\mathrm{NA}$ & NA \\
\hline VR 164A & ExxonMobil & G06668 & $2 / 23 / 2005$ & 41 & NA & NA & 66.0 & NA & NA \\
\hline VR 164A & ExxonMobil & G06668 & $3 / 24 / 2005$ & 704 & NA & NA & 280 & NA & NA \\
\hline VR 164A & ExxonMobil & G06668 & 4/12/2005 & 748 & NA & NA & 280 & NA & NA \\
\hline VR 164A & ExxonMobil & G06668 & $5 / 26 / 2005$ & 108 & NA & NA & 44.5 & NA & NA \\
\hline VR 164A & ExxonMobil & G06668 & $6 / 23 / 2005$ & 1713 & NA & NA & 935 & NA & NA \\
\hline VR 164A & ExxonMobil & G06668 & 6/29/2005 & 186 & NA & NA & 92.0 & NA & NA \\
\hline VR 22B & $\begin{array}{c}\text { Energy Res. } \\
\text { Tech. }\end{array}$ & 2865 & 5/24/2005 & 879 & NA & NA & 374 & NA & NA \\
\hline WC 102G & $\mathrm{BP}$ & 00247 & $3 / 2 / 2005$ & 529 & 400 & 129 & 166 & 137 & 29 \\
\hline
\end{tabular}




\begin{tabular}{|c|c|c|c|c|c|c|c|c|c|}
\hline \multicolumn{10}{|c|}{ Table D-1 - Sample Results for BOD and TOC } \\
\hline $\begin{array}{l}\text { Block \& } \\
\text { Platform } \\
\end{array}$ & Operator & Lease & $\begin{array}{l}\text { Sample } \\
\text { Date }\end{array}$ & $\begin{array}{l}\mathrm{BOD}, \\
\mathrm{mg} / \mathrm{L}\end{array}$ & $\begin{array}{c}\text { Dissolved } \\
\text { BOD, mg/L }\end{array}$ & $\begin{array}{l}\text { Suspended } \\
\text { BOD, mg/L }\end{array}$ & $\begin{array}{l}\text { TOC, } \\
\mathrm{mg} / \mathrm{L}\end{array}$ & $\begin{array}{l}\text { Dissolved } \\
\mathrm{TOC}, \mathrm{mg} / \mathrm{L}\end{array}$ & $\begin{array}{l}\text { Suspended } \\
\text { TOC, mg/L }\end{array}$ \\
\hline WC 102G & $\mathrm{BP}$ & 00247 & $3 / 23 / 2005$ & 328 & NA & NA & 218 & NA & NA \\
\hline WC 102G & $\mathrm{BP}$ & 00247 & $4 / 20 / 2005$ & 579 & NA & NA & 288 & NA & NA \\
\hline WC $110 \mathrm{~A}$ & $\mathrm{BP}$ & 00081 & $3 / 2 / 2005$ & 584 & NA & NA & 280 & NA & NA \\
\hline WC 110A & $\mathrm{BP}$ & 00081 & $3 / 23 / 2005$ & 614 & NA & NA & 374 & $\mathrm{NA}$ & NA \\
\hline WC 110A & $\mathrm{BP}$ & 00081 & $4 / 20 / 2005$ & 792 & 738 & 54 & 370 & 354 & 16 \\
\hline WC 130A & Dominion E\&P & 12761 & $5 / 4 / 2005$ & 804 & NA & NA & 324 & NA & NA \\
\hline WC 168A & Linder Oil & 5238 & $5 / 4 / 2005$ & 80 & NA & NA & 25.6 & NA & NA \\
\hline WC 170A & Nexen Pet. & $\begin{array}{c}\text { OCS-G } \\
4085 \\
\end{array}$ & 4/27/2005 & 198 & NA & NA & 88.5 & NA & NA \\
\hline WC 173K & Houston Expl & 00759 & $5 / 18 / 2005$ & 736 & NA & NA & 320 & NA & NA \\
\hline WC 215A & $\begin{array}{c}\text { Energy Res. } \\
\text { Tech }\end{array}$ & $\begin{array}{c}\text { OCS-G- } \\
4087\end{array}$ & $5 / 2 / 2005$ & 826 & NA & NA & 356 & NA & NA \\
\hline WC 237A & ATP Oil \& Gas & 02833 & $5 / 4 / 2005$ & 1632 & NA & NA & 990 & NA & NA \\
\hline WC 53A & El Paso Prod. & G04379 & $5 / 11 / 2005$ & 167 & 132 & 35 & 71.5 & 66.5 & 5.0 \\
\hline WC 65JA & $\mathrm{BP}$ & G02825 & $3 / 2 / 2005$ & 464 & NA & NA & 31.6 & NA & NA \\
\hline WC 65JA & $\mathrm{BP}$ & G02825 & $3 / 23 / 2005$ & 299 & NA & NA & 29.8 & NA & NA \\
\hline WC 65JA & $\mathrm{BP}$ & G02825 & $4 / 20 / 2005$ & 405 & NA & NA & 124 & NA & NA \\
\hline WC 71D & $\mathrm{BP}$ & 00244 & $4 / 20 / 2005$ & 494 & NA & NA & 206 & $\mathrm{NA}$ & NA \\
\hline WD 45A & Nexen Pet. & $\begin{array}{c}\text { OCS-G } \\
0138 \\
\end{array}$ & 4/28/2005 & 477 & NA & NA & 176 & NA & NA \\
\hline WD 73A & ExxonMobil & G01083 & $2 / 23 / 2005$ & 414 & NA & NA & 61.0 & NA & NA \\
\hline WD 73A & ExxonMobil & G01083 & $3 / 16 / 2005$ & 272 & NA & NA & 188 & NA & NA \\
\hline WD 73A & ExxonMobil & G0183 & 4/27/2005 & 408 & $\mathrm{NA}$ & NA & 154 & $\mathrm{NA}$ & NA \\
\hline WD 89A & ENI Petro. & $\begin{array}{c}\text { OCS-G } \\
1088 \\
\end{array}$ & $5 / 4 / 2005$ & 654 & NA & NA & 110 & NA & NA \\
\hline
\end{tabular}




\begin{tabular}{|c|c|c|c|c|c|c|c|c|c|c|}
\hline \multicolumn{11}{|c|}{ Table D-2 - Sample Results for Parameters Other Than BOD and TOC } \\
\hline $\begin{array}{l}\text { Block \& } \\
\text { Platform }\end{array}$ & $\begin{array}{l}\text { Nitrate, } \\
\mathrm{mg} / \mathrm{L}\end{array}$ & $\begin{array}{l}\text { Nitrite, } \\
\mathrm{mg} / \mathrm{L}\end{array}$ & $\begin{array}{c}\text { Ammonia, } \\
\text { mg/L }\end{array}$ & $\begin{array}{l}\mathrm{TKN} \\
\mathrm{mg} / \mathrm{L}\end{array}$ & $\begin{array}{c}\text { o- } \\
\text { Phosphate, } \\
\text { mg/L }\end{array}$ & $\begin{array}{c}\text { Total } \\
\text { Phosphorus, } \\
\text { mg/L }\end{array}$ & $\begin{array}{c}\text { Temperature, } \\
{ }^{\circ} \mathrm{C}^{\mathrm{a}}\end{array}$ & $\mathrm{pH}, \mathrm{SU}$ & $\begin{array}{c}\text { Conductivity, } \\
\mu \mathrm{mhos} / \mathrm{cm}\end{array}$ & $\begin{array}{c}\text { Salinity, } \\
\text { ppt }\end{array}$ \\
\hline EC 46B & 2.0 & $<0.05$ & 30 & 36.6 & 0.50 & 0.62 & 58 & 7.25 & 55000 & 48.8 \\
\hline EC 47JP & $<0.6$ & $<0.05$ & 74.2 & 76.2 & 8.10 & 10.6 & 25 & $5.24^{\mathrm{b}}$ & 67280 & 58.7 \\
\hline EC 47JP & $<0.6$ & $<0.05$ & 54.2 & 73.6 & 0.16 & 2.50 & 19 & 6.86 & 67800 & 59 \\
\hline EC 47JP & 2.0 & $<0.05$ & 132 & 140 & 0.35 & 2.80 & 27 & 6.68 & 64400 & 57.8 \\
\hline EC 49B & 1.8 & $<0.05$ & 20.2 & 32.0 & 0.27 & 0.50 & 32 & 6.74 & 50600 & 37.0 \\
\hline El 107A & $<0.6$ & $<0.05$ & 115 & 122 & $<0.10$ & $<0.20$ & 26 & 5.56 & 168200 & 245.4 \\
\hline El 107A & $<0.6$ & $<0.05$ & 99.0 & 116 & $<0.10$ & $<0.20$ & 27 & 5.79 & 152500 & 244 \\
\hline El 107A & $<0.6$ & $<0.05$ & 209 & 216 & 0.28 & 0.50 & 32 & 5.50 & 134400 & 242.7 \\
\hline El 128A-JC & 1.7 & $<0.05$ & 183 & 192 & $<0.10$ & $<0.20$ & 45 & 6.49 & 153400 & 190.4 \\
\hline El 172A & 4.0 & $<0.05$ & 36.4 & 42.0 & $<0.10$ & $<0.20$ & 25 & 5.14 & 60500 & 48.8 \\
\hline El 175B & 2.8 & $<0.05$ & 85.8 & 106 & 0.13 & 0.28 & 40 & 6.74 & 129250 & 165.1 \\
\hline El 184A & $<0.6$ & $<0.05$ & 109 & 113 & 0.27 & 0.40 & 60 & 6.25 & 165000 & 217.5 \\
\hline El 50-1 & $<0.6$ & $<0.05$ & 79.2 & 79.0 & 0.51 & 0.64 & 23 & $4.12^{b}$ & 15120 & 10.8 \\
\hline El 57A & $<0.6$ & $<0.05$ & 140 & 154 & $<0.10$ & $<0.20$ & 32 & 6.16 & 144000 & 180.5 \\
\hline El 74A & 0.9 & $<0.05$ & 102 & 111 & 0.12 & 0.38 & 30 & 6.48 & 121000 & 140.8 \\
\hline El 95F & 1.5 & $<0.05$ & 77.8 & 92.0 & 0.20 & 0.31 & 32 & 6.55 & 156600 & 241.8 \\
\hline El 95F & 0.7 & $<0.05$ & 54.2 & 57.6 & 0.17 & $<0.20$ & 33 & 6.68 & 159600 & 248 \\
\hline El 95F & 1.6 & $<0.05$ & 132 & 136 & 0.17 & 0.42 & 33 & 6.43 & 156800 & 261.7 \\
\hline GI 19 \#3 & $<0.6$ & $<0.05$ & 103 & 111 & 0.44 & 0.56 & 28 & 6.66 & 123900 & 136.3 \\
\hline Gl 19\#3 & 1.3 & $<0.05$ & 99.4 & 103 & $<0.10$ & 0.60 & 28 & 6.63 & 124300 & 141 \\
\hline Gl 19\#3 & $<0.6$ & $<0.05$ & 135 & 142 & 0.45 & 0.58 & 32 & 6.72 & 123200 & 142.6 \\
\hline HI 37A & 12.5 & $<0.05$ & 14.8 & 20.2 & 0.12 & $<0.20$ & 29 & 6.32 & 9900 & 6.5 \\
\hline $\mathrm{HI} 39 \mathrm{~A}$ & 15.8 & $<0.05$ & 27.2 & 37.2 & $<0.10$ & 0.36 & 28 & 6.42 & 57200 & 46.0 \\
\hline $\mathrm{HI} 46 \mathrm{~A}$ & $<0.6$ & $<0.05$ & 22.4 & 30.6 & $<0.10$ & $<0.20$ & 30 & 6.92 & 48400 & 39.7 \\
\hline SM 238-190 & 1.4 & $<0.05$ & 69.0 & 80.0 & $<0.10$ & 0.22 & 25 & 6.91 & 88000 & 83.9 \\
\hline SM 268A & 1.7 & $<0.05$ & 64.4 & 74.0 & 0.23 & 0.28 & 48 & 6.66 & 133400 & 160.6 \\
\hline SM 268A & $<0.6$ & $<0.05$ & 106 & 118 & 0.18 & 0.36 & 45 & 6.48 & 123200 & 166.9 \\
\hline SM 40JA & 0.8 & $<0.05$ & 97.8 & 120 & 0.11 & 0.30 & 40 & 4.74 & 120400 & 132.6 \\
\hline SMI 23G & 1.2 & $<0.05$ & 104 & 109 & $<0.10$ & 0.22 & 31 & 6.29 & 120000 & 136.3 \\
\hline SMI 268A & 2.1 & $<0.05$ & 63.0 & 66.0 & 0.16 & 0.42 & 43 & 6.86 & 129950 & 177 \\
\hline SMI 33D & $<0.6$ & $<0.05$ & 51.4 & $46.0^{\mathrm{C}}$ & 0.26 & 0.30 & 29 & 6.99 & 65540 & 54.2 \\
\hline SS 108D & 0.6 & $<0.05$ & 40.0 & 67.4 & 0.10 & $<0.20$ & 29 & 6.56 & 108300 & 117 \\
\hline SS 108D & $<0.6$ & $<0.05$ & 107 & 122 & 0.16 & 0.28 & 42 & 6.74 & 100800 & 119.1 \\
\hline SS 157A & 1.9 & $<0.05$ & 63.4 & 73.0 & 0.12 & 0.26 & 40 & 6.73 & 88000 & 86.6 \\
\hline
\end{tabular}




\begin{tabular}{|c|c|c|c|c|c|c|c|c|c|c|}
\hline \multicolumn{11}{|c|}{ Table D-2 - Sample Results for Parameters Other Than BOD and TOC } \\
\hline $\begin{array}{l}\text { Block \& } \\
\text { Platform }\end{array}$ & $\begin{array}{l}\text { Nitrate, } \\
\mathrm{mg} / \mathrm{L}\end{array}$ & $\begin{array}{c}\text { Nitrite, } \\
\mathrm{mg} / \mathrm{L}\end{array}$ & $\begin{array}{c}\text { Ammonia, } \\
\mathrm{mg} / \mathrm{L}\end{array}$ & $\begin{array}{l}\text { TKN, } \\
\mathrm{mg} / \mathrm{L}\end{array}$ & $\begin{array}{c}\text { o- } \\
\text { Phosphate, } \\
\text { mg/L }\end{array}$ & $\begin{array}{c}\text { Total } \\
\text { Phosphorus, } \\
\text { mg/L }\end{array}$ & $\begin{array}{c}\text { Temperature, } \\
{ }^{0} \mathrm{C}^{\mathrm{a}}\end{array}$ & $\mathrm{pH}, \mathrm{SU}$ & $\begin{array}{c}\text { Conductivity, } \\
\mu \mathrm{mhos} / \mathrm{cm}\end{array}$ & $\begin{array}{c}\text { Salinity, } \\
\text { ppt }\end{array}$ \\
\hline SS 169C & 0.7 & $<0.05$ & 50.2 & 59.4 & 0.12 & $<0.20$ & 41 & 6.80 & 114000 & 144 \\
\hline SS 169C & $<0.6$ & $<0.05$ & 110 & 131 & 0.43 & 0.54 & 47 & 6.43 & 117600 & 148.9 \\
\hline SS 182C & 0.8 & $<0.05$ & 54.2 & 88.6 & $0.24^{\mathrm{d}}$ & $<0.20^{d}$ & 42 & 6.77 & 119700 & 144 \\
\hline SS 182C & $<0.6$ & $<0.05$ & 119 & 147 & 0.11 & 0.32 & 42 & 6.68 & 123200 & 135.4 \\
\hline SS 182E & $<0.6$ & $<0.05$ & 100 & 110 & $<0.10$ & $<0.20$ & 44 & 6.72 & 115500 & 127.2 \\
\hline SS 189A & 0.7 & $<0.05$ & 121 & 128 & 0.15 & 0.32 & 80 & 6.53 & 136800 & 176.9 \\
\hline SS 191B & 1.0 & $<0.05$ & 101 & 178 & $<0.10$ & 0.20 & 65 & 6.19 & 135700 & 217.5 \\
\hline SS 58A & $<0.6$ & $<0.05$ & 75.4 & 82.0 & 0.31 & 6.80 & 40 & 6.24 & 98600 & 106.5 \\
\hline SS 58A & 0.9 & $<0.05$ & 47.4 & 51.2 & $<0.10$ & $<0.20$ & 38 & $3.69^{b}$ & 73450 & 185 \\
\hline SS 58A & $<0.6$ & $<0.05$ & 95 & 110 & $<0.10$ & 0.26 & 40 & 6.56 & 100800 & 108.3 \\
\hline SS108D & 3.8 & $<0.05$ & 76.4 & 87.0 & 0.65 & 0.76 & 42 & 6.85 & 115050 & 119.1 \\
\hline SS169C & 2.8 & $<0.05$ & 102 & 107 & 0.30 & 0.46 & 42 & 6.65 & 129800 & 143.5 \\
\hline SS182C & 1.6 & $<0.05$ & 98.8 & 102 & 0.11 & 0.32 & 40 & 6.89 & 118000 & 132.7 \\
\hline ST 148E & 3.5 & $<0.05$ & 129 & 134 & 0.13 & 0.22 & 40 & 6.08 & 156750 & 203.9 \\
\hline ST 148E & 2.6 & $<0.05$ & 123 & 144 & 0.10 & 0.30 & 40 & 6.34 & 146900 & 211 \\
\hline ST 161A & 1.1 & $<0.05$ & 160 & 168 & $<0.10$ & 0.20 & 70 & 5.89 & 141000 & 167.8 \\
\hline ST 164C & 0.7 & $<0.05$ & 80.8 & 84.2 & 2.80 & 3.0 & 37 & 6.67 & 70800 & 70.4 \\
\hline ST 34A & $<0.6$ & $<0.05$ & 37.8 & $36.2^{\mathrm{e}}$ & 0.16 & 0.28 & 37 & 5.88 & 39440 & 31.6 \\
\hline VR 119G & 0.6 & $<0.05$ & 33.4 & 39.8 & 0.38 & 0.76 & 20 & 7.28 & 79800 & 65.0 \\
\hline VR 119G & 1.1 & $<0.05$ & 16.3 & 28.0 & 0.25 & 0.40 & 35 & 7.06 & 79800 & 73 \\
\hline VR 119G & 0.7 & $<0.05$ & 36.2 & 43.0 & 0.61 & 0.82 & 35 & 7.42 & 78400 & 70.4 \\
\hline VR 164A & $<0.6$ & 0.08 & 4.58 & 5.80 & 0.31 & 0.40 & 31.6 & 6.94 & 11210 & 7.2 \\
\hline VR 164A & 0.9 & $<0.05$ & 47.0 & 51.2 & $<0.10$ & $<0.20$ & 36 & 6.45 & 134400 & 165 \\
\hline VR 164A & $<0.6$ & $<0.05$ & 101 & 118 & $<0.10$ & $<0.20$ & 35 & 6.27 & 128800 & 163.3 \\
\hline VR 164A & 0.7 & $<0.05$ & 7.9 & 11.7 & 0.12 & 0.22 & 26 & 6.72 & 22550 & 17.2 \\
\hline VR 164A & 57.5 & $<0.05$ & 58.0 & 62.8 & $<0.10$ & $<0.20$ & 28 & 5.51 & 99000 & 107 \\
\hline VR 164A & 7.0 & $<0.05$ & 4.81 & 5.46 & $<0.10$ & $<0.20$ & 30 & 6.49 & 51700 & 42.4 \\
\hline VR 22B & 2.4 & $<0.05$ & 27.2 & 35.8 & $<0.10$ & $<0.20$ & 24 & 6.63 & 29425 & 19.9 \\
\hline WC 102G & 2.2 & $<0.05$ & 21.0 & 24.2 & 0.11 & 0.38 & 16 & 6.06 & 34200 & 27.1 \\
\hline WC 102G & 0.8 & $<0.05$ & 6.75 & 9.62 & $<0.10$ & 3.40 & 30 & 6.15 & 912 & 0.5 \\
\hline WC 102G & 1.6 & $<0.05$ & 14.2 & 18.7 & $<0.10$ & $<0.20$ & 22 & 5.58 & 560 & 0.3 \\
\hline WC $110 \mathrm{~A}$ & 0.9 & $<0.05$ & 34.2 & 38.8 & $<0.10$ & $<0.20$ & 16 & 6.48 & 51300 & 45.1 \\
\hline WC $110 A$ & 2.2 & $<0.05$ & 22.5 & 24.4 & $<0.10$ & $<0.20$ & 20 & 6.61 & 54150 & 44 \\
\hline WC $110 \mathrm{~A}$ & 1.7 & $<0.05$ & 51.0 & 51.0 & 0.21 & 0.36 & 25 & 6.16 & 53200 & 45.1 \\
\hline WC 130A & 1.4 & $<0.05$ & 16.0 & 16.9 & $<0.10$ & $<0.10$ & 25 & 5.83 & 11190 & 7.1 \\
\hline
\end{tabular}




\begin{tabular}{|c|c|c|c|c|c|c|c|c|c|c|}
\hline \multicolumn{11}{|c|}{ Table D-2 - Sample Results for Parameters Other Than BOD and TOC } \\
\hline $\begin{array}{l}\text { Block \& } \\
\text { Platform }\end{array}$ & $\begin{array}{c}\text { Nitrate, } \\
\mathrm{mg} / \mathrm{L}\end{array}$ & $\begin{array}{c}\text { Nitrite, } \\
\mathrm{mg} / \mathrm{L}\end{array}$ & $\begin{array}{c}\text { Ammonia, } \\
\mathrm{mg} / \mathrm{L}\end{array}$ & $\begin{array}{l}\text { TKN, } \\
\mathrm{mg} / \mathrm{L}\end{array}$ & $\begin{array}{c}\text { o- } \\
\text { Phosphate, } \\
\text { mg/L }\end{array}$ & $\begin{array}{c}\text { Total } \\
\text { Phosphorus, } \\
\text { mg/L }\end{array}$ & $\begin{array}{c}\text { Temperature, } \\
{ }^{\circ} \mathrm{C}^{\mathrm{a}}\end{array}$ & $\mathrm{pH}, \mathrm{SU}$ & $\begin{array}{c}\text { Conductivity, } \\
\mu \mathrm{mhos} / \mathrm{cm}\end{array}$ & $\begin{array}{c}\text { Salinity, } \\
\text { ppt }\end{array}$ \\
\hline WC 168A & 4.4 & $<0.05$ & 15.7 & 16.8 & 0.20 & 0.27 & 22 & 6.98 & 41810 & 28.9 \\
\hline WC 170A & $<0.6$ & $<0.05$ & 43.0 & 56.0 & $<0.10$ & $<0.20$ & 45 & 6.91 & 69620 & 55.1 \\
\hline WC $173 \mathrm{~K}$ & 4.2 & $<0.05$ & 31.8 & 42.2 & $<0.10$ & $<0.20$ & 29 & 6.52 & 51700 & 39.7 \\
\hline WC 215A & $<0.6$ & $<0.05$ & 51.0 & 60.0 & 6.60 & 7.90 & 62 & 6.94 & 60180 & 46.9 \\
\hline WC 237A & 4.3 & $<0.05$ & 48.0 & 49.6 & 0.11 & 0.12 & 23 & 6.45 & 48590 & 36.1 \\
\hline WC 53A & 0.8 & $<0.05$ & 20.2 & 40.2 & $<0.10$ & 0.26 & 32 & 5.72 & 360 & 0.1 \\
\hline WC 65JA & $<0.6$ & $<0.05$ & 35.2 & 37.2 & 0.15 & 1.44 & 60 & 6.15 & 85500 & 85.7 \\
\hline WC 65JA & 0.9 & $<0.05$ & 21.8 & 26.2 & 0.20 & 0.36 & 58 & 6.73 & 79800 & 84 \\
\hline WC 65JA & $<0.6$ & $<0.05$ & 42.6 & 48.0 & 0.20 & 0.38 & 58 & 6.50 & 81200 & 81.2 \\
\hline WC 71D & $<0.6$ & $<0.05$ & 58.8 & 63.5 & 0.22 & 0.40 & 28 & 6.56 & 95200 & 104.7 \\
\hline WD 45A & 2.9 & $<0.05$ & 96.4 & 101 & 1.05 & 1.50 & 52 & $1.77^{b}$ & 84960 & 79.4 \\
\hline WD 73A & $<0.6$ & $<0.05$ & 93.4 & 97.6 & 0.34 & 0.40 & 42 & 6.75 & 104400 & 99.3 \\
\hline WD 73A & 2.6 & $<0.05$ & 82.0 & 91.0 & 0.41 & 0.94 & 37 & 7.10 & 96050 & 105 \\
\hline WD 73A & 1.0 & $<0.05$ & 191 & 198 & 0.43 & 0.50 & 41.5 & 7.32 & 99120 & 105.6 \\
\hline WD 89A & $<0.6$ & $<0.05$ & 246 & $216^{\dagger}$ & 0.10 & 0.22 & 46 & 6.50 & 127600 & 148.9 \\
\hline
\end{tabular}

${ }^{a}$ The temperatures were measured in the field by personnel on the platforms. Although temperature should have been reported as ${ }^{\circ} \mathrm{C}$, it is likely that some of the values were actually ${ }^{\circ} \mathrm{F}$.

${ }^{b}$ Sample container caps may have been switched in the field, giving a falsely low pH for the sample.

${ }^{c}$ Apparent logical inconsistency. TKN > ammonia. Samples reanalyzed on 6/6/05 after hold time was exceeded; the result was 55.0 mg/L.

${ }^{d}$ Apparent logical inconsistency. Total phosphorus sample rerun with the same result. Orthophosphate sample past holding time, so sample was not rerun.

e Apparent logical inconsistency. TKN > ammonia. Samples reanalyzed on 6/6/05 after hold time was exceeded; the result was 42.6 mg/L.

f Apparent logical inconsistency. TKN > ammonia. Samples reanalyzed on 6/6/05 after hold time was exceeded; the result was 250 mg/L. 


\section{Appendix E - MMS Data on Produced Water Production by Lease during 2003}

\begin{tabular}{|c|c|c|c|c|c|c|c|c|c|c|c|}
\hline $\begin{array}{l}\text { Lease } \\
\text { Block }\end{array}$ & $\begin{array}{c}\text { Water } \\
\text { from Oil } \\
\text { Zones } \\
\text { (bbl) }\end{array}$ & $\begin{array}{l}\text { Water from } \\
\text { Gas Zones } \\
\text { (bbl) }\end{array}$ & $\begin{array}{c}\text { Total } \\
\text { Water } \\
\text { (bbl) }\end{array}$ & $\begin{array}{l}\text { Lease } \\
\text { Block }\end{array}$ & $\begin{array}{c}\text { Water } \\
\text { from Oil } \\
\text { Zones } \\
\text { (bbl) }\end{array}$ & $\begin{array}{l}\text { Water from } \\
\text { Gas Zones } \\
\text { (bbl) }\end{array}$ & $\begin{array}{c}\text { Total } \\
\text { Water } \\
\text { (bbl) }\end{array}$ & $\begin{array}{l}\text { Lease } \\
\text { Block }\end{array}$ & $\begin{array}{c}\text { Water } \\
\text { from Oil } \\
\text { Zones } \\
\text { (bbl) }\end{array}$ & $\begin{array}{l}\text { Water from } \\
\text { Gas Zones } \\
\text { (bbl) }\end{array}$ & $\begin{array}{c}\text { Total } \\
\text { Water } \\
\text { (bbl) }\end{array}$ \\
\hline BM 2 & 294,570 & 78 & 294,648 & $\begin{array}{ll}\text { PL } & 1 \\
\end{array}$ & 150,971 & 16,845 & 167,816 & ST 162 & 0 & 828 & 828 \\
\hline EC 9,14 & 43,980 & 202,187 & 246,167 & PL 2 & 0 & 142,314 & 142,314 & ST 163 & 0 & 2,042 & 2,042 \\
\hline EC 14 & 0 & 98,346 & 98,346 & $\begin{array}{ll}\text { PL } & 5 \\
\end{array}$ & 0 & 33,539 & 33,539 & ST 164 & 30,017 & 978,966 & $1,008,983$ \\
\hline $\begin{array}{ll}\text { EC } 23 \\
\end{array}$ & 0 & 65,622 & 65,622 & $\begin{array}{ll}\text { PL } & 6 \\
\end{array}$ & 0 & 1,790 & 1,790 & ST 165 & 0 & 41,965 & 41,965 \\
\hline EC 24 & 0 & 2,806 & 2,806 & PL 8 & 366,801 & 4,155 & 370,956 & ST 169 & 679,296 & 1,749 & 681,045 \\
\hline EC 32 & 0 & 14,922 & 14,922 & PL 9 & 22,776 & 57,861 & 80,637 & ST 170 & 0 & 7,451 & 7,451 \\
\hline $\begin{array}{ll}\text { EC } 33 \\
\end{array}$ & 0 & 40,505 & 40,505 & $\begin{array}{ll}\text { PL } & 10 \\
\end{array}$ & 490,571 & 746,735 & $1,237,306$ & ST 172 & 15,747 & 0 & 15,747 \\
\hline EC 33 & 0 & 37,820 & 37,820 & PL 11 & 80,523 & 192 & 80,715 & ST 173 & 0 & 67,618 & 67,618 \\
\hline EC 38 & 0 & 53,443 & 53,443 & PL 12 & 113,448 & 52,877 & 166,325 & ST 176 & 94,775 & 31,420 & 126,195 \\
\hline EC 42 & 0 & 395,577 & 395,577 & $\begin{array}{ll}\text { PL } & 12\end{array}$ & 0 & 117 & 117 & ST 193 & 0 & 29,313 & 29,313 \\
\hline $\begin{array}{ll}\text { EC } 45 \\
\end{array}$ & 0 & 1,969 & 1,969 & PL 13 & 81,085 & 160,631 & 241,716 & ST 194 & 0 & 156,976 & 156,976 \\
\hline EC 46 & 598,675 & 2,663 & 601,338 & $\begin{array}{ll}\text { PL } 17 \\
\end{array}$ & 0 & 198,740 & 198,740 & ST 195 & 0 & 97,650 & 97,650 \\
\hline $\begin{array}{ll}\text { EC } 47 \\
\end{array}$ & 174,811 & 139,295 & 314,106 & $\begin{array}{ll}\text { PL } & 18 \\
\end{array}$ & 91 & 26,527 & 26,618 & SX 18 & 0 & 30,318 & 30,318 \\
\hline EC 48 & 0 & 475,399 & 475,399 & $\begin{array}{ll}\text { PL } 19 \\
\end{array}$ & 21,646 & 0 & 21,646 & VR 21 & 0 & 7,214 & 7,214 \\
\hline EC 49 & 0 & 27,724 & 27,724 & PL 20 & 222,099 & 0 & 222,099 & VR 22 & 0 & 86,004 & 86,004 \\
\hline $\begin{array}{ll}\text { EC } & 56 \\
\end{array}$ & 0 & 23,284 & 23,284 & PL 23 & 0 & $1,445,920$ & $1,445,920$ & VR 38 & 4,723 & 5,217 & 9,940 \\
\hline $\begin{array}{ll}\text { EC } 57 \\
\end{array}$ & 0 & 7,279 & 7,279 & PL 24 & 0 & 425,296 & 425,296 & VR 38 & 0 & 83,010 & 83,010 \\
\hline $\begin{array}{ll}\text { EC } \quad 64 \\
\end{array}$ & 319,063 & 854,947 & $1,174,010$ & SA 3 & 0 & 46,923 & 46,923 & VR 39 & 0 & 259,653 & 259,653 \\
\hline $\begin{array}{ll}\text { EC } & 66 \\
\end{array}$ & 0 & 5,407 & 5,407 & SA 6 & 0 & 1,945 & 1,945 & VR 46 & 0 & 286,576 & 286,576 \\
\hline $\begin{array}{ll}\text { EC } & 67 \\
\end{array}$ & 0 & 242,894 & 242,894 & SA 10 & 0 & 6,510 & 6,510 & VR 54 & 0 & 8,756 & 8,756 \\
\hline EC 71 & 0 & 38,145 & 38,145 & SA 13 & 681,708 & 0 & 681,708 & VR 56 & 106,870 & 0 & 106,870 \\
\hline EC 72 & 0 & 27,023 & 27,023 & SM 7 & 0 & 17,141 & 17,141 & VR 57 & 0 & 9,340 & 9,340 \\
\hline EC 76 & 0 & 134,042 & 134,042 & SM 8 & 3,282 & 0 & 3,282 & VR 60 & 0 & 103,115 & 103,115 \\
\hline $\begin{array}{ll}\text { EC } 81 \\
\end{array}$ & 0 & 551,745 & 551,745 & SM 10 & 23,966 & 1,349 & 25,315 & VR 65 & 0 & 2,729 & 2,729 \\
\hline $\begin{array}{ll}\text { EC } 82 \\
\end{array}$ & 0 & 38,175 & 38,175 & SM 11 & 143,241 & 493 & 143,734 & VR 70 & 0 & 54,638 & 54,638 \\
\hline EC 82 & 0 & 6,507 & 6,507 & SM 15 & 124,101 & 0 & 124,101 & VR 78 & 0 & 5,197 & 5,197 \\
\hline EC 83 & 0 & 90,215 & 90,215 & SM 16 & 52,868 & 0 & 52,868 & VR 83 & 0 & 81,469 & 81,469 \\
\hline EC 84 & 0 & 20,785 & 20,785 & SM 18 & 0 & 51,208 & 51,208 & VR 84 & 0 & 464,526 & 464,526 \\
\hline $\begin{array}{ll}\text { EC } & 88 \\
\end{array}$ & 0 & 57,383 & 57,383 & SM 22 & 0 & 3,266 & 3,266 & VR 86 & 0 & 16,226 & 16,226 \\
\hline EC 89 & 122,270 & 27,863 & 150,133 & SM 23 & 0 & 659,570 & 659,570 & VR 100 & 0 & 21,774 & 21,774 \\
\hline EC 109 & 0 & 3,761 & 3,761 & SM 24 & 113 & 5,436 & 5,549 & VR 102 & 0 & 727 & 727 \\
\hline EC 129 & 0 & 2,564 & 2,564 & SM 27 & 28,560 & 1,692 & 30,252 & VR 114 & 0 & 55,579 & 55,579 \\
\hline EC 142 & 0 & 296 & 296 & SM 28 & 0 & 6,319 & 6,319 & VR 115 & 0 & 396 & 396 \\
\hline EC 143 & 0 & 1,502 & 1,502 & SM 29 & 0 & 68,346 & 68,346 & VR 116 & 0 & 38,314 & 38,314 \\
\hline EC 144 & 0 & 57,584 & 57,584 & SM 33 & 104 & 262,826 & 262,930 & VR 117 & 0 & 238 & 238 \\
\hline EC 148 & 0 & 44,578 & 44,578 & SM 34 & 0 & 123,291 & 123,291 & VR 119 & 36,717 & 310,101 & 346,818 \\
\hline EC 149 & 0 & 2,061 & 2,061 & SM 35 & 124,443 & 0 & 124,443 & VR 124 & 159,708 & 0 & 159,708 \\
\hline EC 151 & 0 & 52,133 & 52,133 & SM 36 & 0 & 143,294 & 143,294 & VR 128 & 0 & 46,755 & 46,755 \\
\hline
\end{tabular}




\begin{tabular}{|c|c|c|c|c|c|c|c|c|c|c|c|}
\hline $\begin{array}{l}\text { Lease } \\
\text { Block }\end{array}$ & $\begin{array}{c}\text { Water } \\
\text { from Oil } \\
\text { Zones } \\
\text { (bbl) }\end{array}$ & $\begin{array}{l}\text { Water from } \\
\text { Gas Zones } \\
\text { (bbl) }\end{array}$ & $\begin{array}{l}\text { Total } \\
\text { Water } \\
\text { (bbl) }\end{array}$ & $\begin{array}{l}\text { Lease } \\
\text { Block }\end{array}$ & $\begin{array}{c}\text { Water } \\
\text { from Oil } \\
\text { Zones } \\
\text { (bbl) }\end{array}$ & $\begin{array}{l}\text { Water from } \\
\text { Gas Zones } \\
\text { (bbl) }\end{array}$ & $\begin{array}{l}\text { Total } \\
\text { Water } \\
\text { (bbl) }\end{array}$ & $\begin{array}{l}\text { Lease } \\
\text { Block }\end{array}$ & $\begin{array}{c}\text { Water } \\
\text { from Oil } \\
\text { Zones } \\
\text { (bbl) }\end{array}$ & $\begin{array}{l}\text { Water from } \\
\text { Gas Zones } \\
\text { (bbl) }\end{array}$ & $\begin{array}{c}\text { Total } \\
\text { Water } \\
\text { (bbl) }\end{array}$ \\
\hline EC 154 & 0 & 981 & 981 & SM 37 & 0 & 235,559 & 235,559 & VR 129 & 0 & 8,804 & 8,804 \\
\hline EC 157 & 0 & 1,054 & 1,054 & SM 39 & 415,451 & 395,778 & 811,229 & VR 131 & 0 & 670,397 & 670,397 \\
\hline EC 160 & 0 & 18,152 & 18,152 & SM 48 & 0 & 8,826 & 8,826 & VR 146 & 496,490 & 291,253 & 787,743 \\
\hline EC 161 & 0 & 508 & 508 & SM 49 & 0 & 7,751 & 7,751 & VR 156 & 0 & 128,905 & 128,905 \\
\hline $\begin{array}{lll}\text { EC } 171 \\
\end{array}$ & 0 & 36,678 & 36,678 & SM 61 & 0 & 29,771 & 29,771 & VR 159 & 0 & 64,261 & 64,261 \\
\hline EC 172 & 0 & 27,862 & 27,862 & SM 66 & 0 & 25,189 & 25,189 & VR 160 & 0 & 5,401 & 5,401 \\
\hline EC 179 & 0 & 34,041 & 34,041 & SM 76 & 0 & 10,390 & 10,390 & VR 161 & 0 & 37,131 & 37,131 \\
\hline EC 184 & 0 & 532,540 & 532,540 & SM 77 & 0 & 28,964 & 28,964 & VR 164 & 26,505 & 2,866 & 29,371 \\
\hline EC 195 & 0 & 24,761 & 24,761 & SM 78 & 0 & 12,671 & 12,671 & VR 164 & 0 & 859 & 859 \\
\hline EC 196 & 0 & 41,374 & 41,374 & SM 233 & 0 & 79,086 & 79,086 & VR 175 & 0 & 69,166 & 69,166 \\
\hline EI 47 & 0 & 167,743 & 167,743 & $\begin{array}{l}\text { SM 234, } \\
235\end{array}$ & 0 & 282,972 & 282,972 & VR 182 & $1,204,805$ & 0 & $1,204,805$ \\
\hline EI 49 & 0 & 12,915 & 12,915 & SM 235 & 0 & 13,974 & 13,974 & VR 191 & 0 & 68,511 & 68,511 \\
\hline EI 50 & 0 & 68,147 & 68,147 & SM 243 & 0 & 374 & 374 & VR 201 & 86,560 & 0 & 86,560 \\
\hline $\begin{array}{ll}\text { EI } & 51 \\
\end{array}$ & 0 & 932,115 & 932,115 & SM 244 & 0 & 421,328 & 421,328 & WC 19 & 0 & 1,451 & 1,451 \\
\hline EI 64 & 0 & 28,365 & 28,365 & SM 249 & 0 & 5,357 & 5,357 & $\begin{array}{l}\text { WC 35, } \\
66\end{array}$ & 608,871 & 415 & 609,286 \\
\hline \begin{tabular}{ll|} 
EI & 71 \\
\end{tabular} & 0 & 97,574 & 97,574 & SM 250 & 0 & 15,457 & 15,457 & WC 44 & 0 & 10,241 & 10,241 \\
\hline $\begin{array}{ll}\text { EI } 72 \\
\end{array}$ & 0 & 1,822 & 1,822 & SM 252 & 0 & 8,031 & 8,031 & WC 45 & 0 & 117,411 & 117,411 \\
\hline EI 74 & 0 & 42,150 & 42,150 & SM 253 & 0 & 38 & 38 & WC 46 & 0 & 68,365 & 68,365 \\
\hline EI 87 & 0 & 1,011 & 1,011 & SM 255 & 0 & 114,882 & 114,882 & WC 47 & 0 & 46,338 & 46,338 \\
\hline $\begin{array}{ll}\text { EI } 88 \\
\end{array}$ & 29,715 & 0 & 29,715 & SM 261 & 0 & 204,936 & 204,936 & WC 53 & 0 & 138,749 & 138,749 \\
\hline EI 89 & 0 & 1,785 & 1,785 & SM 268 & 71,091 & 10,143 & 81,234 & WC 54 & 0 & 2,519 & 2,519 \\
\hline EI 95 & 332,446 & 73,479 & 405,925 & SM 269 & 783,389 & 909,563 & $1,692,952$ & WC 60 & 0 & 19,047 & 19,047 \\
\hline $\begin{array}{ll}\text { EI } 97 \\
\end{array}$ & 0 & 105,397 & 105,397 & SM 275 & 0 & 37,609 & 37,609 & WC 61 & 0 & 5,798 & 5,798 \\
\hline EI 99 & 0 & 2,232 & 2,232 & SM 280 & 0 & 14,903 & 14,903 & WC 65 & 178,371 & 210,656 & 389,027 \\
\hline EI 100 & $1,271,180$ & 149,248 & $1,420,428$ & SM 281 & $1,244,955$ & $2,045,633$ & $3,290,588$ & WC 66 & 156,523 & 614,388 & 770,911 \\
\hline EI 105 & 886,106 & 197,552 & $1,083,658$ & SM 288 & 454,327 & 263,288 & 717,615 & WC 67 & 75,243 & 0 & 75,243 \\
\hline EI 106 & 43,003 & 89,790 & 132,793 & SS 58 & 170,987 & 0 & 170,987 & WC 68 & 0 & 177,849 & 177,849 \\
\hline EI 107 & 0 & 94,750 & 94,750 & SS 59 & 47,909 & 152,529 & 200,438 & WC 71 & 0 & 18,397 & 18,397 \\
\hline EI 108 & 0 & 267,817 & 267,817 & SS 63 & 0 & 2,526 & 2,526 & WC 72 & 0 & 27,806 & 27,806 \\
\hline EI 110 & 0 & 777 & 777 & $\begin{array}{ll}\text { SS } & 65, \\
66 & \end{array}$ & 606,781 & 56,190 & 662,971 & WC 73 & 0 & 538 & 538 \\
\hline EI $113 \mathrm{~A}$ & 0 & 22 & 22 & SS 68 & 545,474 & 20,128 & 565,602 & WC 76 & 0 & 603,029 & 603,029 \\
\hline EI 116 & 113,367 & 0 & 113,367 & $\begin{array}{ll}\text { SS } 69 \\
\end{array}$ & $1,214,077$ & 80,127 & $1,294,204$ & WC 77 & 0 & 103,692 & 103,692 \\
\hline EI 118 & 0 & 334,384 & 334,384 & SS 72 & 203,687 & 426,745 & 630,432 & WC 91 & 0 & 98,670 & 98,670 \\
\hline EI 119 & $1,272,435$ & $\begin{array}{r}18,678 \\
1807\end{array}$ & 1,291,113 & $\begin{array}{ll}\text { SS } & 72 \\
\end{array}$ & $\begin{array}{r}1,992 \\
\end{array}$ & 6,972 & 8,964 & WC 98 & 0 & 69,876 & 69,876 \\
\hline EI 120 & $2,145,159$ & 275,866 & $2,421,025$ & SS 76 & 129,681 & 42,568 & 172,249 & WC 100 & 0 & 63,245 & 63,245 \\
\hline EI 125 & 28,219 & 0 & 28,219 & $\begin{array}{ll}\text { SS } 79 \\
\end{array}$ & 0 & 33,837 & 33,837 & WC 101 & 0 & 185,154 & 185,154 \\
\hline EI 126 & $1,012,749$ & 0 & $1,012,749$ & SS 87 & 0 & 774,294 & 774,294 & WC 102 & 0 & 300,796 & 300,796 \\
\hline EI 128 & 594,230 & 0 & 594,230 & SS 91 & 371,285 & 96,281 & 467,566 & WC 110 & 0 & 49,966 & 49,966 \\
\hline
\end{tabular}




\begin{tabular}{|c|c|c|c|c|c|c|c|c|c|c|c|}
\hline $\begin{array}{l}\text { Lease } \\
\text { Block }\end{array}$ & $\begin{array}{c}\text { Water } \\
\text { from Oil } \\
\text { Zones } \\
\text { (bbl) }\end{array}$ & $\begin{array}{l}\text { Water from } \\
\text { Gas Zones } \\
\text { (bbl) }\end{array}$ & $\begin{array}{c}\text { Total } \\
\text { Water } \\
\text { (bbl) }\end{array}$ & $\begin{array}{l}\text { Lease } \\
\text { Block }\end{array}$ & $\begin{array}{c}\text { Water } \\
\text { from Oil } \\
\text { Zones } \\
\text { (bbl) }\end{array}$ & $\begin{array}{l}\text { Water from } \\
\text { Gas Zones } \\
\text { (bbl) }\end{array}$ & $\begin{array}{c}\text { Total } \\
\text { Water } \\
\text { (bbl) }\end{array}$ & $\begin{array}{l}\text { Lease } \\
\text { Block }\end{array}$ & $\begin{array}{c}\text { Water } \\
\text { from Oil } \\
\text { Zones } \\
\text { (bbl) }\end{array}$ & $\begin{array}{l}\text { Water from } \\
\text { Gas Zones } \\
\text { (bbl) }\end{array}$ & $\begin{array}{c}\text { Total } \\
\text { Water } \\
\text { (bbl) }\end{array}$ \\
\hline EI $128 \mathrm{~A}$ & 229,284 & 255,255 & 484,539 & SS 92 & 0 & 42,121 & 42,121 & WC 111 & 0 & 6,059 & 6,059 \\
\hline EI 129 & 354,169 & 4,803 & 358,972 & SS 93 & 236,706 & 26,314 & 263,020 & WC 116 & 0 & 258,674 & 258,674 \\
\hline EI 133 & 2,794 & 13,089 & 15,883 & SS 100 & 883,725 & 0 & 883,725 & WC 118 & 3,131 & 103,366 & 106,497 \\
\hline EI 135 & 0 & 39,816 & 39,816 & SS 103 & 0 & 88,671 & 88,671 & WC 130 & 0 & 7,371 & 7,371 \\
\hline EI 136 & 0 & 28,829 & 28,829 & SS 105 & 0 & 641,889 & 641,889 & WC 132 & 0 & 273 & 273 \\
\hline EI 142 & 1,569 & 0 & 1,569 & SS 108 & $1,453,569$ & 0 & $1,453,569$ & WC 142 & 0 & 2,365 & 2,365 \\
\hline EI 143 & 0 & 3,797 & 3,797 & SS 112 & 102,219 & 165,186 & 267,405 & WC 143 & 0 & 35,164 & 35,164 \\
\hline EI 147 & 0 & 229,209 & 229,209 & SS 113 & 993 & 1,431 & 2,424 & WC 144 & 0 & 129,328 & 129,328 \\
\hline EI 148 & 0 & 164 & 164 & SS 114 & 65,845 & 74,369 & 140,214 & WC 146 & 0 & 7,931 & 7,931 \\
\hline EI 156 & 0 & 6,394 & 6,394 & SS 117 & 189,426 & 0 & 189,426 & WC 148 & 0 & 154,013 & 154,013 \\
\hline EI 157 & 0 & 33,291 & 33,291 & SS 126 & 0 & $1,046,529$ & $1,046,529$ & WC 149 & 0 & 367 & 367 \\
\hline EI 158 & 822,454 & 449,740 & $1,272,194$ & SS 129 & 2,472 & 93,790 & 96,262 & WC 150 & 0 & 11,844 & 11,844 \\
\hline EI 159 & 0 & 275 & 275 & SS 130 & 0 & 168 & 168 & WC 152 & 0 & 25,660 & 25,660 \\
\hline EI 162 & 0 & 57,756 & 57,756 & SS 133 & 0 & 4,837 & 4,837 & WC 153 & 0 & 51,092 & 51,092 \\
\hline EI 163 & 0 & 3,946 & 3,946 & SS 139 & 0 & 168,530 & 168,530 & WC 163 & 0 & 902 & 902 \\
\hline EI 167 & 10,536 & 0 & 10,536 & SS 148 & 10,413 & 241 & 10,654 & WC 165 & 0 & 106 & 106 \\
\hline EI 172 & 0 & 5,606 & 5,606 & SS 149 & 258,608 & 28,585 & 287,193 & WC 168 & 0 & 13,308 & 13,308 \\
\hline EI 173 & 411,323 & 0 & 411,323 & SS 150 & 183,176 & 55,564 & 238,740 & WC 170 & 0 & $2,292,199$ & $2,292,199$ \\
\hline EI 174 & 80,555 & 25,663 & 106,218 & SS 151 & 92,706 & 0 & 92,706 & WC 171 & 0 & 5,812 & 5,812 \\
\hline EI 175 & 193,386 & 333,943 & 527,329 & SS 154 & 686,375 & 816,637 & $1,503,012$ & WC 172 & 0 & 3,535 & 3,535 \\
\hline EI 176 & 20,481 & 0 & 20,481 & SS 156 & 193,598 & 0 & 193,598 & WC 173 & 0 & 103,717 & 103,717 \\
\hline EI 177 & 0 & 4,786 & 4,786 & SS 157 & 0 & 3,362 & 3,362 & WC 176 & 8,450 & 2,020 & 10,470 \\
\hline EI 181 & 100,040 & 0 & 100,040 & SS 159 & 0 & 216,208 & 216,208 & WC 178 & 97,555 & 0 & 97,555 \\
\hline EI 182 & 194,944 & 134,432 & 329,376 & SS 166 & 0 & 3,962 & 3,962 & WC 180 & 0 & 206,770 & 206,770 \\
\hline EI 183 & 215,879 & 0 & 215,879 & SS 168 & 0 & 14,527 & 14,527 & WC 182 & 0 & 74,154 & 74,154 \\
\hline EI 184 & $1,611,791$ & 0 & $1,611,791$ & SS 169 & 897,323 & 132,134 & $1,029,457$ & WC 191 & 0 & 1,146 & 1,146 \\
\hline EI 187 & 0 & 11,695 & 11,695 & SS 170 & 0 & 249 & 249 & WC 192 & 0 & 99,333 & 99,333 \\
\hline EI 188 & 662,405 & 0 & 662,405 & SS 171 & 169,422 & 0 & 169,422 & WC 193 & 0 & 127,393 & 127,393 \\
\hline EI 189 & 324,328 & 382,420 & 706,748 & SS 175 & 118,988 & 0 & 118,988 & WC 194 & 0 & 146,298 & 146,298 \\
\hline EI 190 & 0 & 216 & 216 & SS 177 & 128,102 & 0 & 128,102 & WC 195 & 0 & 4,189 & 4,189 \\
\hline EI 193 & 199,493 & 213,926 & 413,419 & SS 178 & 579,977 & 147,930 & 727,907 & WC 196 & 0 & 21,091 & 21,091 \\
\hline EI 196 & 0 & 75,433 & 75,433 & SS 181 & $1,129,471$ & 226,527 & $1,355,998$ & WC 197 & 0 & 20,435 & 20,435 \\
\hline EI 196 & 0 & 42 & 42 & SS 182 & $1,634,645$ & 0 & $1,634,645$ & WC 198 & 0 & 103,750 & 103,750 \\
\hline EI 198 & 0 & 14,447 & 14,447 & SS 182 & 530,594 & 94,476 & 625,070 & WC 206 & 0 & 31,345 & 31,345 \\
\hline EI 199 & 0 & 5,619 & 5,619 & SS 183 & $1,433,862$ & 95,119 & $1,528,981$ & WC 210 & 0 & 506 & 506 \\
\hline EI 202 & 0 & 179,446 & 179,446 & SS 184 & 0 & 18,109 & 18,109 & WC 215 & 568,702 & 3,244 & 571,946 \\
\hline EI 203 & 0 & 406 & 406 & SS 187 & 0 & 116,337 & 116,337 & WC 222 & 0 & 3,585 & 3,585 \\
\hline EI 205 & 0 & 452,181 & 452,181 & SS 189 & 0 & 382,254 & 382,254 & WC 225 & 0 & 108,386 & 108,386 \\
\hline EI 206 & 0 & 6 & 6 & SS 190 & 0 & 270,784 & 270,784 & WC 226 & 0 & 5,049 & 5,049 \\
\hline EI 208 & 722,390 & 0 & 722,390 & SS 191 & 0 & 154,259 & 154,259 & WC 229 & 0 & 176,099 & 176,099 \\
\hline EI 211 & 76,647 & 0 & 76,647 & SS 193 & $1,153,791$ & 23 & $1,153,814$ & WC 238 & 0 & 9,816 & 9,816 \\
\hline
\end{tabular}




\begin{tabular}{|c|c|c|c|c|c|c|c|c|c|c|c|}
\hline $\begin{array}{l}\text { Lease } \\
\text { Block }\end{array}$ & $\begin{array}{c}\text { Water } \\
\text { from Oil } \\
\text { Zones } \\
\text { (bbl) }\end{array}$ & $\begin{array}{l}\text { Water from } \\
\text { Gas Zones } \\
\text { (bbl) }\end{array}$ & $\begin{array}{l}\text { Total } \\
\text { Water } \\
\text { (bbl) }\end{array}$ & $\begin{array}{l}\text { Lease } \\
\text { Block }\end{array}$ & $\begin{array}{c}\text { Water } \\
\text { from Oil } \\
\text { Zones } \\
\text { (bbl) }\end{array}$ & $\begin{array}{l}\text { Water from } \\
\text { Gas Zones } \\
\text { (bbl) }\end{array}$ & $\begin{array}{l}\text { Total } \\
\text { Water } \\
\text { (bbl) }\end{array}$ & $\begin{array}{l}\text { Lease } \\
\text { Block }\end{array}$ & $\begin{array}{c}\text { Water } \\
\text { from Oil } \\
\text { Zones } \\
\text { (bbl) }\end{array}$ & $\begin{array}{l}\text { Water from } \\
\text { Gas Zones } \\
\text { (bbl) }\end{array}$ & $\begin{array}{c}\text { Total } \\
\text { Water } \\
\text { (bbl) }\end{array}$ \\
\hline EI 212 & 0 & 427,763 & 427,763 & SS 194 & 87,683 & 0 & 87,683 & WC 239 & 0 & 35,289 & 35,289 \\
\hline EI 214 & 0 & 39,333 & 39,333 & SS 198 & 332,246 & 352,473 & 684,719 & WC 248 & 0 & 58,746 & 58,746 \\
\hline EI 215 & 137,107 & 0 & 137,107 & SS 198 & 110,547 & 787,699 & 898,246 & WC 269 & 0 & 2,056 & 2,056 \\
\hline EI 217 & 0 & 525 & 525 & SS 206 & 422,638 & 0 & 422,638 & WC 289 & 0 & 4,645 & 4,645 \\
\hline EI 218 & 8,234 & 0 & 8,234 & SS 207 & $1,664,805$ & 162,794 & $1,827,599$ & WC 290 & 0 & 272 & 272 \\
\hline EI 224 & 34,518 & 171,899 & 206,417 & SS 208 & 779,501 & 17,089 & 796,590 & WC 291 & 0 & 69,522 & 69,522 \\
\hline EI 229 & 0 & 2,681 & 2,681 & SS 214 & 194,952 & 158,296 & 353,248 & WC 293 & 0 & 1,292 & 1,292 \\
\hline EI 230 & 0 & 10,028 & 10,028 & SS 215 & 167,597 & 5,004 & 172,601 & WC 294 & 0 & 885,697 & 885,697 \\
\hline EI 231 & 0 & 840 & 840 & SS 216 & 0 & $1,442,582$ & $1,442,582$ & WC 300 & 0 & 19,437 & 19,437 \\
\hline EI 237 & 143,240 & 6,975 & 150,215 & ST 21 & $3,524,548$ & 252,963 & $3,777,511$ & WC 304 & 0 & 315 & 315 \\
\hline EI 238 & 0 & 5,817 & 5,817 & ST 22 & $1,721,085$ & 29,792 & $1,750,877$ & WC 310 & 0 & 5,677 & 5,677 \\
\hline EI 240 & 29,689 & 34,901 & 64,590 & ST 23 & 942,041 & 0 & 942,041 & WC 313 & 0 & 6,436 & 6,436 \\
\hline EI 242 & 0 & 7,391 & 7,391 & ST 23 & $1,619,003$ & 0 & $1,619,003$ & WC 315 & 0 & 23,032 & 23,032 \\
\hline EI 243 & 0 & $1,137,471$ & $1,137,471$ & ST 24 & $1,728,171$ & 0 & $1,728,171$ & WC 331 & 0 & 58 & 58 \\
\hline GI 17 & 1,624 & 0 & 1,624 & ST 26 & 352,376 & 0 & 352,376 & WC 343 & 0 & 96,601 & 96,601 \\
\hline GI 18 & 79,354 & 0 & 79,354 & ST 26 & $1,765,655$ & 199,781 & $1,965,436$ & WC 347 & 0 & 29,044 & 29,044 \\
\hline GI 19 & 806,935 & 0 & 806,935 & ST 27 & 16,261 & 0 & 16,261 & WD 21 & 0 & 16,373 & 16,373 \\
\hline GI 20 & 0 & 14,752 & 14,752 & ST 28 & 0 & 198 & 198 & WD 23 & 0 & 10,413 & 10,413 \\
\hline GI 21,30 & 160,466 & 0 & 160,466 & ST 35 & 795,012 & 65,980 & 860,992 & WD 24 & 223,216 & 111,376 & 334,592 \\
\hline GI 22 & $2,164,101$ & 0 & $2,164,101$ & ST 36 & 236,362 & 264,740 & 501,102 & WD 27 & 981,193 & 188,315 & $1,169,508$ \\
\hline GI 23 & $3,591,721$ & 0 & $3,591,721$ & ST 37 & $5,547,354$ & $1,280,793$ & $6,828,147$ & WD 28 & 144,936 & 7,865 & 152,801 \\
\hline GI 26 & 588,405 & 0 & 588,405 & ST 38 & 0 & 136,096 & 136,096 & WD 29 & $2,186,488$ & 7,757 & $2,194,245$ \\
\hline GI 28 & 0 & 226 & 226 & ST 48 & 0 & 254,749 & 254,749 & WD 30 & $8,215,453$ & 0 & $8,215,453$ \\
\hline GI 32 & 463,811 & 334,104 & 797,915 & ST 51 & $3,189,226$ & 253,472 & $3,442,698$ & WD 31 & $2,595,223$ & 0 & $2,595,223$ \\
\hline GI 32 & 372,632 & 240,214 & 612,846 & ST 52 & $2,433,453$ & 38,811 & $2,472,264$ & WD 32 & 745,268 & 9,132 & 754,400 \\
\hline GI 33 & 643,575 & 175,730 & 819,305 & ST 53 & $4,414,797$ & 0 & $4,414,797$ & WD 32 & 77,669 & 0 & 77,669 \\
\hline $\begin{array}{ll}\text { GI } 37 \\
\end{array}$ & 910,964 & 0 & 910,964 & ST 54 & $2,127,092$ & 11,369 & $2,138,461$ & WD 32 & 262,035 & 0 & 262,035 \\
\hline GI 40 & $2,063,561$ & 48,530 & $2,112,091$ & ST 55 & 0 & 32,364 & 32,364 & WD 34 & 0 & 291,696 & 291,696 \\
\hline GI 41 & $1,888,323$ & 158,281 & $2,046,604$ & ST 63 & 0 & 59,229 & 59,229 & WD 35 & 0 & 205,785 & 205,785 \\
\hline GI 41 & 0 & $1,497,091$ & $1,497,091$ & ST 66 & 1,759 & 0 & 1,759 & WD 38 & 34,592 & 0 & 34,592 \\
\hline GI 42 & 162,771 & 7,582 & 170,353 & ST 67 & $1,593,028$ & 45,255 & $1,638,283$ & WD 39 & 0 & 2,284 & 2,284 \\
\hline GI 43 & 0 & 222,269 & 222,269 & ST 68 & 270,659 & 0 & 270,659 & WD 41 & 95,725 & 709,390 & 805,115 \\
\hline $\begin{array}{ll}\text { GI } 45 \\
\end{array}$ & 0 & 23,277 & 23,277 & ST 71 & 0 & 171,459 & 171,459 & WD 44 & 167,993 & 862,241 & $1,030,234$ \\
\hline GI 46 & 0 & 246,375 & 246,375 & ST 72 & 199,348 & 61,839 & 261,187 & WD 45 & $1,673,021$ & 134,876 & $1,807,897$ \\
\hline GI 47 & $2,525,220$ & 144,064 & $2,669,284$ & ST 76 & 0 & 152,197 & 152,197 & WD 58 & 0 & $1,490,896$ & $1,490,896$ \\
\hline GI 48 & 506,412 & 176,548 & 682,960 & ST 77 & 0 & 221,663 & 221,663 & WD 59 & 0 & 94,428 & 94,428 \\
\hline GI 52 & 0 & 760,439 & 760,439 & ST 99 & 0 & 21 & 21 & WD 61 & 0 & 552,357 & 552,357 \\
\hline HI 36 & 0 & 4,331 & 4,331 & ST 100 & 0 & 376,893 & 376,893 & WD 63 & 0 & 176,436 & 176,436 \\
\hline HI 37 & 0 & 4,339 & 4,339 & ST 107 & 0 & 6,717 & 6,717 & WD 65 & 0 & 21,737 & 21,737 \\
\hline HI 38 & 0 & 5,153 & 5,153 & ST 111 & 0 & 96 & 96 & WD 68 & 0 & 23,234 & 23,234 \\
\hline $\begin{array}{ll}\text { HI } & 39\end{array}$ & 0 & 8,725 & 8,725 & ST 112 & 0 & 33,658 & 33,658 & WD 70 & $3,450,635$ & 374,179 & $3,824,814$ \\
\hline
\end{tabular}




\begin{tabular}{|c|c|c|c|c|c|c|c|c|c|c|c|}
\hline $\begin{array}{l}\text { Lease } \\
\text { Block }\end{array}$ & $\begin{array}{c}\text { Water } \\
\text { from Oil } \\
\text { Zones } \\
\text { (bbl) }\end{array}$ & $\begin{array}{l}\text { Water from } \\
\text { Gas Zones } \\
\text { (bbl) }\end{array}$ & $\begin{array}{l}\text { Total } \\
\text { Water } \\
\text { (bbl) }\end{array}$ & $\begin{array}{l}\text { Lease } \\
\text { Block }\end{array}$ & $\begin{array}{c}\text { Water } \\
\text { from Oil } \\
\text { Zones } \\
\text { (bbl) }\end{array}$ & $\begin{array}{l}\text { Water from } \\
\text { Gas Zones } \\
\text { (bbl) }\end{array}$ & $\begin{array}{l}\text { Total } \\
\text { Water } \\
\text { (bbl) }\end{array}$ & $\begin{array}{l}\text { Lease } \\
\text { Block }\end{array}$ & $\begin{array}{c}\text { Water } \\
\text { from Oil } \\
\text { Zones } \\
\text { (bbl) }\end{array}$ & $\begin{array}{l}\text { Water from } \\
\text { Gas Zones } \\
\text { (bbl) }\end{array}$ & $\begin{array}{l}\text { Total } \\
\text { Water } \\
\text { (bbl) }\end{array}$ \\
\hline $\begin{array}{ll}\mathrm{HI} & 45 \\
\end{array}$ & 0 & 6,012 & 6,012 & ST 128 & 0 & 33,503 & 33,503 & WD 71 & $1,650,267$ & 302,976 & $1,953,243$ \\
\hline HI 47 & 0 & 1,942 & 1,942 & ST 130 & 326,389 & 0 & 326,389 & WD 72 & 0 & 25,920 & 25,920 \\
\hline HI 72 & 0 & 32,837 & 32,837 & ST 139 & 0 & 8,448 & 8,448 & WD 73 & $1,408,764$ & 371,734 & $1,780,498$ \\
\hline $\begin{array}{l}\text { HI } 84 \\
\end{array}$ & 0 & 5,372 & 5,372 & ST 143 & 0 & 3,611 & 3,611 & WD 74 & $3,007,589$ & 58 & $3,007,647$ \\
\hline $\begin{array}{ll}\mathrm{HI} & 85 \\
\end{array}$ & 0 & 51,062 & 51,062 & ST 146 & 0 & 1,065 & 1,065 & WD 95 & $1,781,786$ & 36,100 & $1,817,886$ \\
\hline HI 129 & 0 & 42,640 & 42,640 & ST 148 & 734,268 & 54,615 & 788,883 & WD 96 & 555,012 & 0 & 555,012 \\
\hline HI 166 & 0 & 1,650 & 1,650 & ST 148 & 0 & 145,664 & 145,664 & & & & \\
\hline HI 167 & 0 & 478,170 & 478,170 & ST 161 & 0 & 24,684 & 24,684 & & & & \\
\hline
\end{tabular}

Total Water from Oil Zones =

Total Water from Gas Zones =

$125,122,378 \mathrm{bbl} /$ year

Total Water $=$

$60,199,843 \mathrm{bbl} /$ year

$185,322,221 \mathrm{bbl} /$ year 